\title{
Synthesis, Characterization, and Reactivity Studies of Heterodinuclear Complexes Modeling Active Sites in Purple Acid Phospatases
}

\author{
Martin Jarenmark, ${ }^{* \dagger}{ }^{+}$Matti Haukka, ${ }^{\ddagger}$ Serhiy Demeshko, ${ }^{\S}$ Felix Tuczek,, Luca Zuppiroli, ${ }^{\perp}$ Franc Meyer, ${ }^{\S}$ and \\ Ebbe Nordlander ${ }^{*+}$ \\ ${ }^{\dagger}$ Inorganic Chemistry Research Group, Chemical Physics, Center for Chemistry and Chemical Engineering, Lund University, Box 124, \\ SE-221 00 Lund, Sweden \\ ${ }^{\ddagger}$ Department of Chemistry, University of Eastern Finland, P.O. Box 111, FI-80101 Joensuu, Finland \\ §Institute for Inorganic Chemistry, Georg-August-University Göttingen, Tammanstrasse 4, D-37077 Göttingen, Germany \\ "Institute for Inorganic Chemistry, Christian-Albrechts-University Kiel, Olshausenstrasse 40, D-24098 Kiel, Germany \\ ${ }^{\perp}$ Dipartimento di Chimica “A. Mangini”, Universita di Bologna, Viale Risorgimento 4, I-40136 Bologna, Italy
}

Supporting Information

ABSTRACT: To model the heterodinuclear active sites in plant purple acid phosphatases, a mononuclear synthon, [Fe(III)$\left.\left(\mathrm{H}_{2} \mathrm{IPCPMP}\right)\left(\mathrm{Cl}_{2}\right)\right]\left[\mathrm{PF}_{6}\right](\mathbf{1})$, has been generated in situ from the ligand 2-(N-isopropyl- $N$-((2-pyridyl)methyl)aminomethyl)6-(N-(carboxylmethyl)- $N-((2$-pyridyl) methyl)amino methyl)-4 methylphenol (IPCPMP) and used to synthesize heterodinuclear complexes of the formulas [Fe(III)M(II)(IPCPMP) $(\mathrm{OAc})_{2^{-}}$ $\left.\left(\mathrm{CH}_{3} \mathrm{OH}\right)\right]\left[\mathrm{PF}_{6}\right](\mathrm{M}=\mathrm{Zn}$ (2), Co (3), Ni (4), Mn (5)), $[\mathrm{Fe}(\mathrm{III}) \mathrm{Zn}(\mathrm{II})(\mathrm{IPCPMP})(\mathrm{mpdp})]\left[\mathrm{PF}_{6}\right]$ (6) (mpdp = metaphenylene-dipropionate), and $[\mathrm{Fe}(\mathrm{III}) \mathrm{Cu}(\mathrm{II})(\mathrm{IPCPMP})$ $\left.(\mathrm{OAc})\}_{2}(\mu-\mathrm{O})\right]\left[\mathrm{PF}_{6}\right](7)$. Complexes $2-4,6$, and 7 have been crystallographically characterized. The structure of 6 is a solid

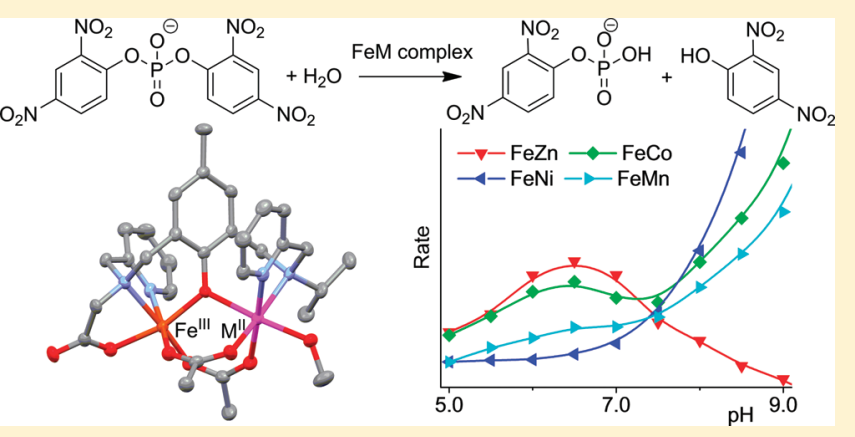
state coordination polymer with heterodinuclear monomeric units, and 7 is a tetranuclear complex consisting of two heterodinuclear phenolate-bridged $\mathrm{Fe}(\mathrm{III}) \mathrm{Cu}$ (II) units bridged through a $\mu$-oxido group between the two $\mathrm{Fe}(\mathrm{III})$ ions. Mössbauer spectra confirm the presence of high spin $\mathrm{Fe}(\mathrm{III})$ in an octahedral environment for 1, 3, and 5 while $\mathbf{2}$ and 4 display relaxation effects. Magnetic susceptibility measurements indicate weak antiferromagnetic coupling for 3, 4, and $\mathbf{5}$ and confirm the assignment of the metal centers in $\mathbf{2}-\mathbf{5}$ as high spin $\mathrm{Fe}(\mathrm{III})-\mathrm{M}(\mathrm{II})(\mathrm{M}=\mathrm{Zn}$, Co (high spin), $\mathrm{Ni}$ (high spin), $\mathrm{Mn}$ (high spin)). Complexes $\mathbf{2}-\mathbf{5}$ are intact in acetonitrile solution as indicated by IR spectroscopy (for 2-4) and electrospray ionization mass spectrometry (ESI-MS) but partly dissociate to hydroxide species and a mononuclear complex in water/acetonitrile solutions. UV-vis spectroscopy reveal $\mathrm{pH}$-dependent behavior, and species that form upon increasing the $\mathrm{pH}$ have been assigned to $\mu$-hydroxido-bridged Fe(III)M(II) complexes for $\mathbf{2}-\mathbf{5}$ although 2 and $\mathbf{3}$ is further transformed into what is propsed to be a $\mu$-oxido-bridged tetranuclear complex similar to 7 . Complexes $\mathbf{2}-\mathbf{5}$ enhance phosphodiester cleavage of 2-hydroxy-propyl-p-nitrophenyl phosphate (HPNP) and bis(2,4-dinitrophenyl)phosphate (BDNPP), but the reactivities are different for different complexes and generally show strong $\mathrm{pH}$ dependence.

\section{INTRODUCTION}

Transition metal ions are extensively used by nature to catalyze a broad range of reactions. ${ }^{1}$ While the presence of one metal in the active site is sufficient for the activity of many metalloenzymes, others have evolved to make use of a multinuclear active site where the metals work in a cooperative way with similar or very different roles. Important examples of protein/enzyme classes containing polynuclear metal sites include nitrogenases, ${ }^{2,3}$ oxygenases, ${ }^{4,5}$ hydrogenases, ${ }^{6}$ iron-sulfur proteins, ${ }^{7}$ oxygen transport proteins, ${ }^{8,9}$ the oxygen evolving complex of photosystem $\mathrm{II}^{10,11}$ and $\mathrm{di}$ - and trinuclear hydrolases. ${ }^{12}$ The latter is a diverse group regarding structures, substrate selectivity, and metal content but their modes of action are very similar. ${ }^{13,14}$ They are employed to hydrolyze substrates such as urea (urease), ${ }^{13,14}$ peptide bonds in proteins (e.g., leucine aminopeptidase $^{15}$ ), phosphotriesters (phosphotriesterase ${ }^{16}$ ), DNA and RNA (e.g., DNA polymerase and RNase $\mathrm{H}^{17}$ ). These enzymes have active sites where two metals of the same kind bind in close proximity to each other (about $2.9-4 \AA$ apart). ${ }^{12}$ Two other members of the hydrolase superfamily, the purple acid phosphatases (PAPs) ${ }^{18-20}$ and Ser/Thr Protein Phosphatases (PPs), ${ }^{12,18}$ are special in that they have been shown to bind two different metal ions in their active sites. While the true (native)

Received: October 6, 2010

Published: March 31, 2011 
metal content of PPs has not been completely established, the PAPs are known to have a requirement of one $\mathrm{Fe}(\mathrm{III})$ and a divalent metal (Fe(II), $\mathrm{Zn}(\mathrm{II})$, or $\mathrm{Mn}(\mathrm{II})$ ) in their active sites.

Purple acid phosphatases are nonspecific phosphomonoesterases isolated from various mammals and plants. The specific functions of these enzymes appear to be dependent on the organism. In mammals they have been associated with regulation of bone resorption in osteoclasts ${ }^{20}$ and iron transport during pregnancy. ${ }^{21}$ Plant PAPs might have a role in recruiting phosphate in developing plants. ${ }^{22}$ Typical characteristics of PAP enzymes are their intense pink/purple color, the low $\mathrm{pH}$ optimum $(\sim \mathrm{pH} 5-6)$ of their activity, and their resistance to tartrate inhibition. ${ }^{12,18,19}$ Several PAPs from mammalian and plant sources (human, ${ }^{23}$ pig, ${ }^{24}$ rat, ${ }^{25,26}$ kidney bean, ${ }^{27,28}$ and sweet potato ${ }^{29}$ ) have been structurally characterized by crystallography. The mammalian enzymes have a heterovalent Fe(III) $\mathrm{Fe}$ (II) metal site in its active form, but only structures of the inactive oxidized di-Fe(III) state have been determined so far. The plant PAPs, which have very low sequence homology with the mammalian enzymes, have two different metal ions in the active site, $\mathrm{Fe}(\mathrm{III})$ and either $\mathrm{Zn}(\mathrm{II})^{30-32}$ or $\mathrm{Mn}(\mathrm{II}){ }^{32,33}$ Despite the relatively low sequence homology between PAPs from different sources, the amino acid residues forming the coordination environment of the metals are conserved in all PAPs. A notable feature of the active sites (Figure 1) is the unsymmetric coordination of the two metals. The Fe(III) resides in an oxygenrich environment with the relatively hard donors aspartate and phenolate; the latter amino acid residue is involved in a ligand to metal charge transfer (LMCT) interaction with the $\mathrm{Fe}$ (III) responsible for the intense color of the enzyme. The divalent metal occupies a site with one more nitrogen donor and an asparagine but no anionic ligands except the bridging hydroxido moiety and a $\mu_{1,1}-\kappa^{1}(\mathrm{O})$ aspartate group. In sweet potato PAP (spPAP), which contains an $\mathrm{Fe}(\mathrm{III}) \mathrm{Mn}$ (II) active site, the observed strong antiferromagnetic coupling between the two metal ions indicates a bridging oxido rather than a $\mu$-hydroxido ligand. ${ }^{33}$ In the general PAP active site, the divalent metal has a water molecule coordinated to it, and the $\mathrm{Fe}(\mathrm{III})$ has been modeled with a terminally coordinated hydroxido group, $25,27,28$ although some spectroscopic evidence speak against this. ${ }^{34}$ This discrepancy is also one of the issues that are discussed when it comes to the mechanism(s) of these enzymes. Investigations have led to the conclusion that a solvent-derived nucleophile coordinated to (at least) the $\mathrm{Fe}$ (III) makes a direct attack on the phosphorus atom of the substrate with inversion of its configuration, but whether this nucleophile is terminally coordinated or bridging between the metals has not been established with certainty. Also, the exact binding of the substrate prior to hydrolysis is under debate and might be $\mathrm{pH}$-dependent. ${ }^{18}$ The fact that the pig PAP uteroferrin, which in its native form contains a $\mathrm{Fe}$ (III) $\mathrm{Fe}$ (II) core, and the kidney bean PAP (with an $\mathrm{Fe}$ (III) $\mathrm{Zn}(\mathrm{II})$ core) both exhibit diesterase activity, that is, hydrolyze both an organophosphate diester and the monoester that is the product of the initial hydroslysis, has been interpreted to mean that the phosphate ester coordinates in a terminal fashion to the divalent metal of the enzyme active site, and that hydrolysis is effected by a hydroxyl nucleophile that is generated at and terminally coordinated to the ferric ion, ${ }^{35}$ a mechanism that is corroborated by reactivity studies of a dinuclear $\mathrm{Fe}(\mathrm{III}) \mathrm{Zn}$ (II) model complex. ${ }^{36}$ In a recent investigation on uteroferrin and its $\mathrm{Fe}(\mathrm{III}) \mathrm{Mn}$ (II) derivative, Schenk and co-workers ${ }^{37}$ studied the hydrolysis of phenyl phosphate by the enzyme, using stopped-

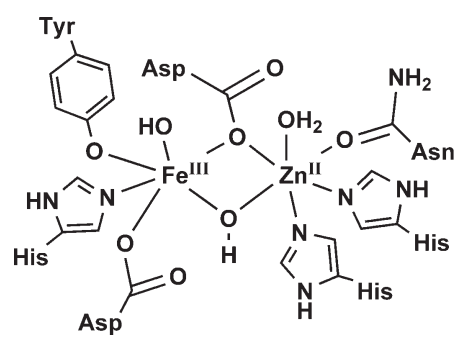

Figure 1. Structure of the active site in kidney bean purple acid phosphatase in the resting state based on crystallographic and spectroscopic data. Adapted from ref 18.

flow spectrophotometry. The investigators found that substrate hydrolysis occurred at a faster rate than the formation of a $\mu-1,3-$ phosphate complex for both forms of the metalloenzyme. A slower rate of interaction between the substrate and the ferric ion relative to the catalytic rate was interpreted to mean that the substrate is hydrolyzed when coordinated in a monodentate fashion to the divalent metal, and the authors suggested that the active hydroxide nucleophile is generated by the action of a $\mathrm{Fe}$ (III)-coordinated hydroxide ion on a water molecule in the second coordination sphere of the metal core, aided by histidine residues capable of acting as Brönsted bases (vide infra).

Small dinuclear metal complexes have been extensively used to model metal sites in enzymes. ${ }^{38-41}$ The synthesis of heterodinuclear complexes presents a special challenge because of the possibility of disproportionation and selectivity problems when the metals are coordinated to a dinucleating ligand; such problems may result in the formation of mixtures of homoand heterodinuclear complexes, as well as metal site isomers. These difficulties have been circumvented by designing ligands that bind metals selectively in one pocket or strongly enough to prevent disproportionation and metal mixing. Different types of ligands that have been successfully used to model PAPs are illustrated in Figure 2. Symmetric ligands (BPMP, ${ }^{42} \mathrm{BPBP}^{43}$ $\mathrm{BPMOP}^{44}$ etc., type (a) Figure 2) do not have the problem of metal site selectivity and since they bind the metals strongly because of the chelate effect, selective formation of heterodinuclear complexes is possible although investigation of true species distribution in various solvents have not always been reported. Unsymmetric ligands frequently utilize a hard and anionic oxygen donor on one side to selectively bind the Fe(III), and only nitrogen donors on the side that preferentially binds the divalent metal (e.g., BPBPMP, ${ }^{45}$ BHBBPMP $^{46}$ Figure 2).

We have previously reported the two unsymmetric ligands IPCPMP $^{47}$ and ICIMP ${ }^{48}$ (Figure 2, type a) that incorporate a terminal carboxylate donor as well as pyridyl and 1-methylimidazolyl groups, respectively. The terminal carboxylate moiety models the oxygen-rich environment often found in active sites of metalloenzymes. ${ }^{1}$ On the opposite side, a noncordinating group has been incorporated to further model the unsymmetric coordination of the metal sites and to provide for a site on the bound metal that is either vacant or filled by a (loosely) coordinated ligand. The two ligands have been shown to selectively bind $\mathrm{Fe}$ (III) on one side of the phenolate, forming mononuclear $\mathrm{Fe}$ (III) complexes that have been isolated and characterized, and that have been used as synthons for heterodinuclear $\mathrm{Fe}(\mathrm{III}) \mathrm{Zn}$ (II) complexes that are capable of enhancing the rate of transesterification of 2-hydroxypropyl-p-nitrophenylphosphate (HPNP) relative to the noncatalyzed reaction. ${ }^{49}$ Here 
<smiles>[R]CN(C[R])Cc1cc([R3])cc(CN(C[R])C[R])c1O</smiles>

(a)<smiles>[R]CN(C[R6])CC(O)CN(C[R6])C[R]</smiles>

(b)

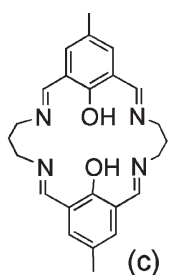

(c)<smiles>O=C([O-])CCc1cccc(CCC(=O)[O-])c1</smiles>

(d)

Figure 2. Schematic depiction of ligands that have been used to model active sites in PAPs. Type (a) includes ICIMP $(\mathrm{R} 1=\mathrm{R} 4=1$-metylimidazole, $\mathrm{R} 2=$ $\mathrm{CO}_{2}{ }^{-}, \mathrm{R} 3=$ iso-propyl; $\left.\mathrm{R} 5=\mathrm{CH}_{3}\right)$ BPBPMP $\left(\mathrm{R} 1=\mathrm{R} 2=\mathrm{R} 3=2\right.$-pyridyl, $\mathrm{R} 4=2$-phenolate, $\left.\mathrm{R} 5=\mathrm{CH}_{3}\right), \mathrm{BPMP}(\mathrm{R} 1=\mathrm{R} 2=\mathrm{R} 3=\mathrm{R} 4=2$-pyridyl, $\mathrm{R} 5=$ $\left.\mathrm{CH}_{3}\right), \mathrm{BPBP}(\mathrm{R} 1=\mathrm{R} 2=\mathrm{R} 3=\mathrm{R} 4=2$-pyridyl, $\mathrm{R} 5=t$-butyl), $\mathrm{BHBBPMP}(\mathrm{R} 1=\mathrm{R} 2=2$-pyridyl, $\mathrm{R} 3=\mathrm{R} 4=2$-phenol, $\mathrm{R} 5=\mathrm{CH}$ ), $\mathrm{BPMOP}(\mathrm{R} 1=\mathrm{R} 2=\mathrm{R} 3=$ $\mathrm{R} 4=2$-pyridyl, $\mathrm{R} 5=$ methoxy $)$. Type $(\mathrm{b})$ includes tdmbpo $(\mathrm{R} 7=\mathrm{R} 8=4,5$-dimethyl $)$ benzimidazolyl $)$; thebpo $(\mathrm{R} 7=\mathrm{R} 8=(2$-hydroxyethyl)benzimidazolyl); bdmbbppo (R7 = (4,5-dimethyl)benzimidazolyl, R8 = 2-pyridyl. (c) Macrocyclic bis-phenolato ligand. The present study involves type (a) IPCPMP ( $\mathrm{R} 1=\mathrm{R} 4=2$-pyridyl, $\mathrm{R} 2=\mathrm{CO}_{2}{ }^{-}, \mathrm{R} 3=$ iso-propyl, $\mathrm{R} 5=\mathrm{CH}_{3}$ ) (d) 1,3-meta-phenylenedipropionate (mpdp).

\section{Chart 1. Schematic Depiction of the New Complexes Presented in This Work}

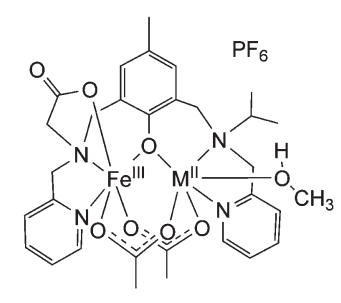

[Fe(III)M(II)IPCPMP(OAc) $\left.)_{2}\left(\mathrm{CH}_{3} \mathrm{OH}\right)\right]\left[\mathrm{PF}_{6}\right.$ $M^{\prime \prime}=\mathrm{Zn}(2), \mathrm{Co}(3), \mathrm{Ni}(4), \mathrm{Mn}(5)$

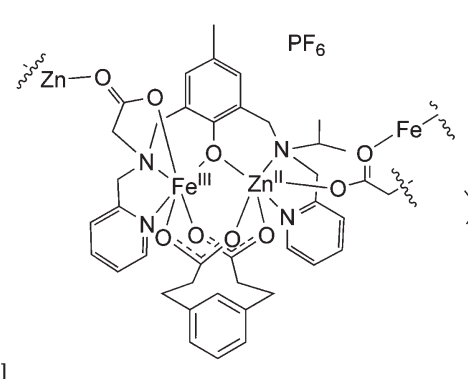

$[\mathrm{Fe}(\mathrm{III}) \mathrm{Zn}(\mathrm{II}) \mathrm{IPCPMP}(\mathrm{mpdp})]\left[\mathrm{PF}_{6}\right](\mathbf{6})$

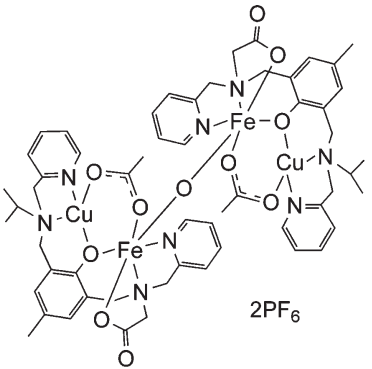

$[\mathrm{Fe}(\mathrm{III}) \mathrm{Cu}(\mathrm{II}) \mathrm{IPCPMP}(\mathrm{OAc})(\mathrm{O})]\left[\mathrm{PF}_{6}\right](7)$ we report a detailed study of other heterodinuclear complexes of the type $\mathrm{Fe}(\mathrm{III}) \mathrm{M}$ (II) (M(II) = Zn(II), Co(II), Ni(II), Cu(II), and $\mathrm{Mn}(\mathrm{II})$ ) that are based on IPCPMP, and further solution and reactivity investigations to elucidate the mechanism(s) and relevance of these complexes as models of the active sites in purple acid phosphatases.

\section{RESULTS AND DISCUSSION}

Syntheses. The complexes in this study have been synthesized by two different methods, both of which proceed via the in situ formation of the mononuclear synthon $\left[\mathrm{Fe}(\mathrm{III})\left(\mathrm{H}_{2} \mathrm{IPCPMP}\right)\right.$ $\left.\left(\mathrm{Cl}_{2}\right)\right]\left[\mathrm{PF}_{6}\right](\mathbf{1})^{49}$ by addition of 1 equiv of $\mathrm{FeCl}_{3}$ to a solution of the ligand. Addition of divalent metals $(\mathrm{Zn}, \mathrm{Co}, \mathrm{Ni}, \mathrm{Mn}, \mathrm{Cu})$ with appropriate carboxylate donors to this solution have made it possible to isolate several different heterodinuclear complexes (Chart 1) of the formula [Fe(III)M(II)(IPCPMP)(OAc) $2_{2}$ $\left.\left(\mathrm{CH}_{3} \mathrm{OH}\right)\right]\left[\mathrm{PF}_{6}\right]\left(\mathrm{M}=\mathrm{Zn}(2),{ }^{49} \mathrm{Co}(3), \mathrm{Ni}(4), \mathrm{Mn}(5)\right)$ as well as two other of the formulas [Fe(III) $\mathrm{Zn}(\mathrm{II})(\mathrm{IPCPMP})(\mathrm{mpdp})]-$ $\left[\mathrm{PF}_{6}\right](6)(\mathrm{mpdp}=$ meta-phenylene-dipropionate, Figure $2 \mathrm{~d})$ and $[\mathrm{Fe}(\mathrm{III}) \mathrm{Cu}(\mathrm{II})(\mathrm{IPCPMP})(\mathrm{OAc})\}_{2}(\mu$-O) $]\left[\mathrm{PF}_{6}\right]$ (7). To achieve coordination of the divalent metal, the mononuclear synthon (1) needs to be deprotonated. The first method (method A) used a dropwise addition of 6 equiv of tributyl amine, during which the intense blue color of 1 gradually changed to less intense red-purple for 2-6 while for $7(\mathrm{FeCu})$ the color turned red-brown. From these solutions, X-ray quality crystals were grown for $2(\mathrm{FeZn}), 3$ (FeCo), 4 (FeNi), 6 (FeZn-mpdp), and 7 (FeCu), but so far no suitable crystals have been grown for $\mathbf{5}(\mathrm{FeMn})$ (the structure of the analogous compound [FeMn(ICIMP $\left.)(\mathrm{OAc})_{2} \mathrm{Cl}\right]$ has been determined by X-ray crystallography $\left.{ }^{50}\right)$. During efforts to scale up this synthetic method for $2(\mathrm{FeZn})$ and $\mathbf{4}(\mathrm{FeNi})$, contamination by tributyl ammonium hexafluorophoshate often interfered with the isolation of the product. To circumvent this problem, a second method (method B) was devised, in which an excess of sodium acetate (6 equiv) dissolved in methanol was added dropwise. Filtration through Celite removed the precipitated sodium salts, and crystalline material of $\mathbf{2}$ and $\mathbf{4}$ could be grown in good yields from methanol/2-propanol solvent mixtures. All analyses favor the formulation of these complexes as having the same composition as those obtained using the first method, except for the case of the $\mathrm{Fe}(\mathrm{III}) \mathrm{Cu}$ (II) complex 7, where method $\mathrm{B}$ did not yield a pure product.

Solid State Structures. The structures of $\mathbf{1}$ and $\mathbf{2}$ have been reported previously, ${ }^{49}$ and ORTEP illustrations are shown in Figure 3. The crystal structures of 3 and $4[\mathrm{Fe}(\mathrm{III}) \mathrm{M}(\mathrm{II})$ $\left.(\mathrm{IPCPMP})(\mathrm{OAc})_{2}\left(\mathrm{CH}_{3} \mathrm{OH}\right)\right]\left[\mathrm{PF}_{6}\right](\mathrm{M}=\mathrm{Co}(3)$ and $\mathrm{Ni}(4)$, Figure 4 ) are very similar to that of $2(\mathrm{FeZn})$; crystallographic data for 3 and $\mathbf{4}$ are summarized in Table 1 , and relevant bond distances and angles for $\mathbf{2 - 4}$ are listed in Table 2. In the case of 3 and 4 , both metals are octahedrally coordinated in an $\mathrm{N}_{2} \mathrm{O}_{4}$ environment with one phenolate and two syn-syn- $\mu_{1,3}$-carboxylate bridges. The $\mathrm{Fe}(\mathrm{III})$ ion is in all cases found on the side with the hard terminal carboxylate donor of IPCPMP, and this carboxylate coordinates in the anti mode while the usual mode for carboxylate donors in biological systems is syncoordination. ${ }^{51}$ A methanol molecule derived from the solvent coordinates at the site on the divalent metal ion that is left open by the noncoordinating isopropyl group. The bonds to the $\mathrm{Fe}(\mathrm{III})$ ion are on average the same for $2-4$ but shorter than those to the divalent metal $\left(\mathrm{Fe}-\mathrm{X}_{\text {ave }}\right.$ 2-4: $2.04 \AA ; \mathrm{Zn}-\mathrm{X}_{\text {ave }} 2$ : 2.12; $3: 2.12 ; 4: 2.08 \AA$ ) although the bond to the pyridyl. 

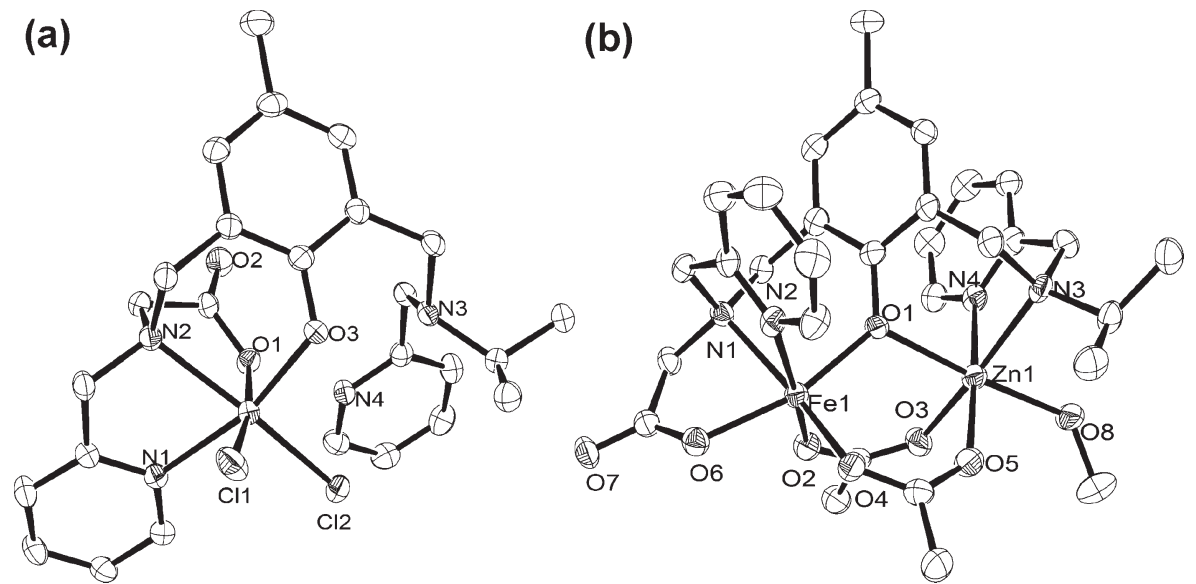

Figure 3. ORTEP ${ }^{96}$ representations of $\left[\mathrm{Fe}(\mathrm{III})\left(\mathrm{H}_{2} \mathrm{IPCPMP}\right)\left(\mathrm{Cl}_{2}\right)\right]\left[\mathrm{PF}_{6}\right](\mathbf{1})(\mathrm{a})$ and $\left[\mathrm{Fe}(\mathrm{III}) \mathrm{Zn}(\mathrm{II})(\mathrm{IPCPMP})(\mathrm{OAc})_{2}\left(\mathrm{CH}_{3} \mathrm{OH}\right)\right]\left[\mathrm{PF}_{6}\right](2)(\mathrm{b})$ from ref 49.
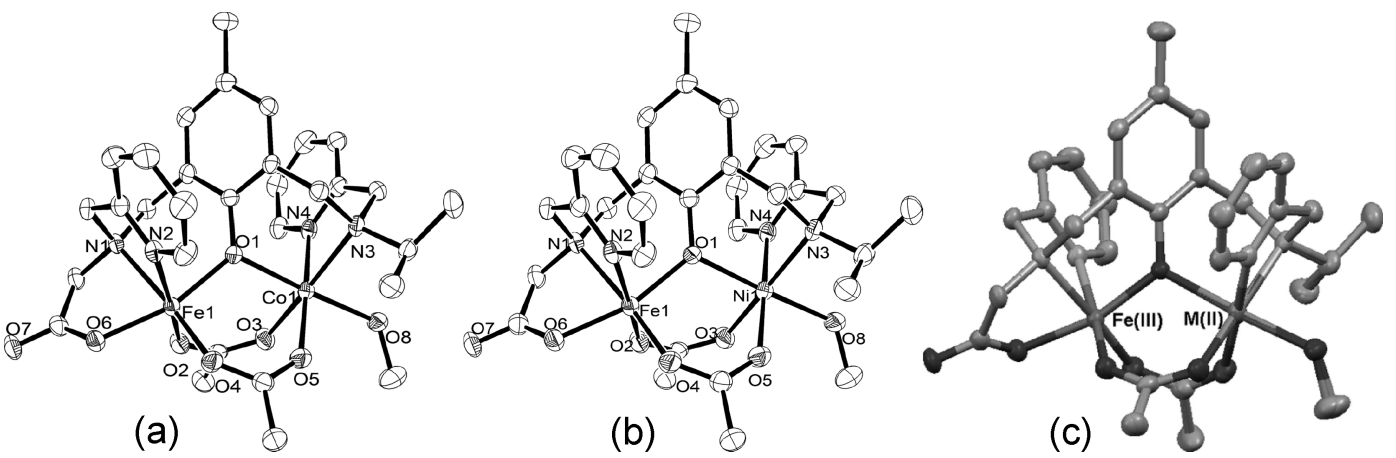

Figure 4. ORTEP representations of the crystal structures of $\left[\mathrm{Fe}(\mathrm{III}) \mathrm{Co}(\mathrm{II})(\mathrm{IPCPMP})(\mathrm{OAc})_{2}\left(\mathrm{CH}_{3} \mathrm{OH}\right)\right]\left[\mathrm{PF}_{6}\right] \quad(3) \quad(\mathrm{a})$ and $\left[\mathrm{Fe}(\mathrm{III}) \mathrm{Ni}(\mathrm{II})(\mathrm{IPCPMP})(\mathrm{OAc})_{2}\left(\mathrm{CH}_{3} \mathrm{OH}\right)\right]\left[\mathrm{PF}_{6}\right]$ (4) (b) along with a Mercury ${ }^{97}$ overlay structure of complexes 2, 3, and 4 (c), where $\mathrm{M}(\mathrm{II})=$ $\mathrm{Zn}(\mathrm{II}), \mathrm{Co}(\mathrm{II})$, or $\mathrm{Ni}(\mathrm{II})$, respectively. All solvent molecules and counterions have been omitted for clarity, and the ellipsoids are drawn at $50 \%$ probability. The $(R, R)$ enantiomers are shown in (a) and (b) while in (c) only the $(S, S)$ enantiomers were overlaid.

nitrogen is actually significantly longer $(\mathrm{Fe} 1-\mathrm{N} 2$ 2: 2.165(3); 3: $2.162(2) ; 4: 2.258(3) \AA)$ than the corresponding one to the divalent metal ion (Zn1-N4 2: 2.115(3); 3: 2.100(2); 4: 2.048(3) A. Shorter bonds are to be expected for Fe(III) because of its small size and high charge-to-radius ratio. Divalent metal ions are considerably softer than the hard $\mathrm{Fe}$ (III) ion and hence have stronger interactions with pyridyl groups that are relatively soft compared to alkyl amines and oxygen groups. This effect is also seen for $\mathbf{2}$ and $\mathbf{3}$ when comparing distances between the metals and the relatively hard tertiary nitrogens, where the metal-nitrogen distances are shorter for $\mathrm{Fe}(\mathrm{III})(\mathrm{Fe} 1-\mathrm{N} 12$,

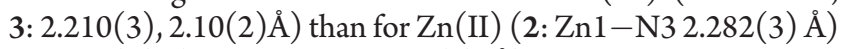
and $\mathrm{Co}(\mathrm{II})(3$ : $\mathrm{Co} 1-\mathrm{N} 32.268(3) \AA$ ). The same distance to $\mathrm{Ni}(\mathrm{II})$ in 4 (Ni1-N3 2.210(3) $\AA$ ) is identical to the corresponding $\mathrm{Fe}-\mathrm{N}$ distance $(\mathrm{Fe} 1-\mathrm{N} 1$ 2,209(3) Å) which might reflect the higher charge-to-radius ratio of $\mathrm{Ni}$ (II) as compared to $\mathrm{Zn}$ (II) and $\mathrm{Co}$ (II) (vide infra). The shortened bonds to $\mathrm{Fe}(\mathrm{III})$ also make all three bridging moieties unsymmetrically coordinated between the two metals with significantly longer bonds to the divalent metal ion (Average $\mathrm{Fe}-\mathrm{O}_{\text {bridge }} 2$ : 1.95, 3: 1.96; 4: $\left.1.96 \AA ; \mathrm{M}(\mathrm{II})-\mathrm{O}_{\text {bridge }} 2(\mathrm{Zn}): 2.10 ; 3(\mathrm{Co}): 2.08 ; 4(\mathrm{Ni}): 2.06 \AA\right)$. Also, the two carboxylate bridges coordinate at slightly different distances to the $\mathrm{Fe}$ (III) with the one trans to the tertiary amine at shorter distance, as observed by others. ${ }^{52}$ It is a bit surprising to note that the distances between metals and tertiary nitrogens are longer (average for 2-4: Fe1-N1 2.21 $\mathrm{Z}, \mathrm{Zn1}-\mathrm{N} 32.25 \AA$ ) than the corresponding ones to pyridyl nitrogens (average for 2-4: Fe1-N2 2.16 ̊, Zn1-N4 2.09 ̊). This has previously been ascribed to the strain introduced by the limited length of the onecarbon linker between the tertiary nitrogen and the three attached donor groups $^{53}$ (e.g., phenolate, pyridyl, carboxylate). Also, the clamping effect of the bridges will pull the metals away from the tertiary nitrogen that has limited flexibility because of its linkage to the phenol ring.

To facilitate the comparison of complexes 2 (FeZn), 3 $(\mathrm{FeCo})$, and $4(\mathrm{FeNi})$, an overlay plot of their structures is shown in Figure 4c. It is apparent that they are virtually identical, with root-mean-square deviations varying from 0.039 to 0.054 depending on which two structures are compared. A detailed comparison of the bond lengths (Table 2) shows that the only significant differences are observed for the bonds to the divalent metal ion. The $\mathrm{Fe}(\mathrm{III})-\mathrm{X}$ distances $(\mathrm{X}=\mathrm{N}$ - or O-donor $)$ average to 2.038, 2.040, and $2.040 \AA$ for 2, 3, and 4, respectively. All bonds to $\mathrm{Ni}(\mathrm{II})$ in $4\left(\mathrm{Ni}-\mathrm{X}_{\text {ave }}=2.083 \AA\right)$ are shorter than the corresponding ones to $\mathrm{Zn}$ (II) and $\mathrm{Co}$ (II) in 2 and 3, the latter ones being quite similar $\left(\mathrm{Zn}-\mathrm{X}_{\mathrm{ave}}=2.129 \AA\right.$; $\left.\mathrm{Co}-\mathrm{X}_{\mathrm{ave}}=2.116 \AA\right)$. This is likely an effect of the smaller ionic radius of $\mathrm{Ni}$ (II) (0.83 $\AA$ vs 0.88 and $0.885 \AA$ for $\mathrm{Zn}$ (II) and high spin $\mathrm{Co}$ (II), 
Table 1. Crystallographic Data for Complex 2, 3, 4, 6, and 7 (L = IPCPMP)

\begin{tabular}{|c|c|c|c|c|c|}
\hline & $\begin{array}{l}{\left[\mathrm{FeZnL}(\mathrm{OAc})_{2}\right.} \\
\left.\left(\mathrm{CH}_{3} \mathrm{OH}\right)\right] \mathrm{PF}_{6}\end{array}$ & $\begin{array}{l}{\left[\mathrm{FeCoL}(\mathrm{OAc})_{2}\right.} \\
\left.\left(\mathrm{CH}_{3} \mathrm{OH}\right)\right] \mathrm{PF}_{6}\end{array}$ & $\begin{array}{l}{\left[\mathrm{FeNiL}(\mathrm{OAc})_{2}\right.} \\
\left.\left(\mathrm{CH}_{3} \mathrm{OH}\right)\right] \mathrm{PF}_{6}\end{array}$ & $\begin{array}{c}{[\mathrm{FeZnL}(\mathrm{mpdp})]} \\
\mathrm{PF}_{6}\end{array}$ & $\begin{array}{c}{\left[\{\mathrm{FeCuL}(\mathrm{OAc})\}_{2}\right.} \\
(\mu-\mathrm{O})] \mathrm{PF}_{6} \cdot\left(\mathrm{CH}_{3} \mathrm{OH}\right)_{2}\end{array}$ \\
\hline & 2 & 3 & 4 & 6 & 7 \\
\hline empirical formula & $\mathrm{C}_{31} \mathrm{H}_{40} \mathrm{~F}_{6} \mathrm{FeN}_{4} \mathrm{O}_{8} \mathrm{PZn}$ & $\mathrm{C}_{31} \mathrm{H}_{40} \mathrm{CoF}_{6} \mathrm{FeN}_{4} \mathrm{O}_{8} \mathrm{P}$ & $\mathrm{C}_{31} \mathrm{H}_{40} \mathrm{~F}_{6} \mathrm{FeN}_{4} \mathrm{NiO}_{8} \mathrm{P}$ & $\mathrm{C}_{38} \mathrm{H}_{42} \mathrm{~F}_{6} \mathrm{FeN}_{4} \mathrm{O}_{7} \mathrm{PZn}$ & $\mathrm{C}_{60} \mathrm{H}_{82} \mathrm{Cu}_{2} \mathrm{~F}_{12} \mathrm{Fe}_{2} \mathrm{~N}_{8} \mathrm{O}_{15} \mathrm{P}_{2}$ \\
\hline$M_{\mathrm{r}}(\mathrm{g} / \mathrm{mol})$ & 862.86 & 856.42 & 856.20 & 932.95 & 1684.06 \\
\hline $\begin{array}{l}\text { crystal size }\left(\mathrm{mm}^{3}\right) \\
\text { crystal system }\end{array}$ & $\begin{array}{l}0.24 \times 0.08 \times 0.06 \\
\text { monoclinic }\end{array}$ & $\begin{array}{l}0.29 \times 0.14 \times 0.12 \\
\text { monoclinic }\end{array}$ & $\begin{array}{l}0.30 \times 0.29 \times 0.20 \\
\text { monoclinic }\end{array}$ & $\begin{array}{l}0.20 \times 0.13 \times 0.13 \\
\text { monoclinic }\end{array}$ & $\begin{array}{l}0.14 \times 0.08 \times 0.07 \\
\text { monoclinic }\end{array}$ \\
\hline space group & $P n$ & $P n$ & $P n$ & $P 2_{1} / c$ & $P 2_{1} / n$ \\
\hline$a(\AA)$ & $10.4594(5)$ & $10.4714(2)$ & $10.4533(3)$ & $18.9033(6)$ & $12.4979(6)$ \\
\hline$b(\AA)$ & $13.6060(9)$ & $13.6885(4)$ & $13.6671(4)$ & $13.7500(7)$ & $22.0221(12)$ \\
\hline$c(\AA)$ & $12.7267(7)$ & $12.6895(4)$ & $12.6719(2)$ & $14.9602(5)$ & $12.9244(4)$ \\
\hline$\alpha(\operatorname{deg})$ & 90 & 90 & 90 & 90 & 90 \\
\hline$\beta(\operatorname{deg})$ & $99.665(3)$ & $99.067(2)$ & $98.781(2)$ & $90.290(2)$ & $103.126(3)$ \\
\hline$\gamma(\operatorname{deg})$ & 90 & 90 & 90 & 90 & 90 \\
\hline volume $\left(\AA^{3}\right)$ & $1785.44(18)$ & $1796.16(9)$ & $1789.17(8)$ & $3888.4(3)$ & $3464.2(3)$ \\
\hline Z & 2 & 2 & 2 & 4 & 2 \\
\hline$\rho_{\text {calc. }}\left(\mathrm{g} / \mathrm{cm}^{3}\right)$ & 1.605 & 1.584 & 1.589 & 1.594 & 1.614 \\
\hline $\begin{array}{l}\text { abs. coefficient } \\
\left(\mathrm{mm}^{-1}\right)\end{array}$ & 1.209 & 0.995 & 1.062 & 1.115 & 1.164 \\
\hline$F(000)$ & 886 & 880 & 882 & 1916 & 1732 \\
\hline wavelength $(\AA)$ & 0.71073 & 0.71073 & 0.71073 & 0.71073 & 0.71073 \\
\hline temperature $(\mathrm{K})$ & $120(2)$ & $120(2)$ & $120(2)$ & $120(2)$ & $120(2)$ \\
\hline$\theta$ range $(\mathrm{deg})$ & 3.58 to 27.53 & 2.20 to 27.49 & 3.57 to 27.52 & 2.01 to 25.01 & 1.86 to 25.35 \\
\hline \multirow[t]{3}{*}{ index ranges } & $-13 \leq h \leq 12$ & $-13 \leq h \leq 13$ & $-13 \leq h \leq 13$ & $-20 \leq h \leq 22$ & $-14 \leq h \leq 15$ \\
\hline & $-17 \leq k \leq 17$ & $-17 \leq k \leq 17$ & $-17 \leq k \leq 17$ & $-15 \leq k \leq 16$ & $-26 \leq k \leq 26$ \\
\hline & $-16 \leq l \leq 16$ & $-16 \leq l \leq 16$ & $-16 \leq l \leq 16$ & $-17 \leq l \leq 17$ & $-15 \leq l \leq 15$ \\
\hline reflns collected & 15909 & 41179 & 30688 & 22376 & 27601 \\
\hline indep. reflns $\left[R_{\text {int }}\right]$ & 7003 [0.0379] & 8155 [0.0439] & $8007[0.0375]$ & $6768[0.0635]$ & $6330[0.0971]$ \\
\hline $\begin{array}{l}\text { compltnss to } \\
\qquad \theta=27.53^{\circ}\end{array}$ & $99.2 \%$ & $99.9 \%$ & $99.5 \%$ & $98.7 \%$ & $99.8 \%$ \\
\hline absorpn correction & $\begin{array}{l}\text { semiempirical } \\
\text { from equivalents }\end{array}$ & $\begin{array}{l}\text { semiempirical } \\
\text { from equivalents }\end{array}$ & $\begin{array}{l}\text { semiempirical } \\
\text { from equivalents }\end{array}$ & $\begin{array}{l}\text { semiempirical } \\
\text { from equivalents }\end{array}$ & $\begin{array}{l}\text { semiempirical } \\
\text { from equivalents }\end{array}$ \\
\hline $\begin{array}{l}\max . \text { and } \min \\
\text { transmisn }\end{array}$ & 0.9267 and 0.7610 & 0.8941 and 0.7598 & 0.8181 and 0.7433 & 0.8668 and 0.8045 & 0.9240 and 0.8521 \\
\hline refinement method & $\begin{array}{l}\text { full-matrix least- } \\
\text { squares on } F^{2}\end{array}$ & $\begin{array}{l}\text { full-matrix least- } \\
\text { squares on } F^{2}\end{array}$ & $\begin{array}{l}\text { full-matrix least- } \\
\text { squares on } F^{2}\end{array}$ & $\begin{array}{l}\text { full-matrix least- } \\
\text { squares on } F^{2}\end{array}$ & $\begin{array}{l}\text { full-matrix least- } \\
\text { squares on } F^{2}\end{array}$ \\
\hline $\begin{array}{l}\text { data/restrnts/ } \\
\text { paramtrs }\end{array}$ & $7003 / 2 / 495$ & $8155 / 51 / 488$ & $8007 / 50 / 488$ & $6768 / 0 / 526$ & $6330 / 0 / 466$ \\
\hline $\begin{array}{l}\text { goodness-of- } \\
\text { fit on } F^{2}\end{array}$ & 1.015 & 1.035 & 1.029 & 1.005 & 1.026 \\
\hline \multirow[t]{2}{*}{$\begin{array}{l}\text { final } R \text { indices } \\
\qquad[I>2 \sigma(I)]\end{array}$} & $\mathrm{R} 1=0.0383$ & $\mathrm{R} 1=0.0367$ & $\mathrm{R} 1=0.0393$ & $\mathrm{R} 1=0.0352$ & $\mathrm{R} 1=0.0515$ \\
\hline & $\mathrm{wR} 2=0.0846$ & $\mathrm{wR} 2=0.0868$ & $\mathrm{wR} 2=0.0931$ & $\mathrm{wR} 2=0.0811$ & $\mathrm{wR} 2=0.1190$ \\
\hline \multirow[t]{2}{*}{$R$ indices (all data) } & $\mathrm{R} 1=0.0509$ & $\mathrm{R} 1=0.0456$ & $\mathrm{R} 1=0.0497$ & $\mathrm{R} 1=0.0590$ & $\mathrm{R} 1=0.0948$ \\
\hline & $\mathrm{wR} 2=0.0903$ & $\mathrm{wR} 2=0.0916$ & $\mathrm{wR} 2=0.0976$ & $\mathrm{wR} 2=0.0908$ & $\mathrm{wR} 2=0.1377$ \\
\hline $\begin{array}{l}\text { resid electrn dens } \\
\qquad\left(\mathrm{e} \AA^{-3}\right)\end{array}$ & $0.568 /-0.445$ & $0.627 /-0.564$ & $0.624 /-0.456$ & $0.408 /-0.403$ & $0.929 /-0.707$ \\
\hline
\end{tabular}

respectively $)^{54}$ as noted previously for similar FeNi and FeZn complexes of the ligand BPMP. ${ }^{55}$ The coordination environments of the divalent metals in 2 ( $\mathrm{Zn}$ (II)) and 3 (Co(II)) differ only with regard to the bond to the phenolic oxygen, which is longest in $2(2.137(2) \AA)$ and of similar lengths in 3 and 4 (2.075(2) and 2.068(2) $\AA$, respectively). This difference is probably due to the $\pi$-donation from the p-orbitals of the phenolic oxygen to suitable metal d-orbitals, which is absent for $\mathrm{Zn}$ (II) because of its $\mathrm{d}^{10}$ configuration but present for the other two metals. The metal-metal distances are quite similar, namely, 3.4556(6) $\AA$, 3.4351(5), and 3.4273(5) Å for 2, 3, and 4, respectively, and the small differences that are observed may be 


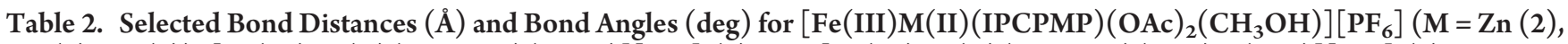
Co (3), Ni (4)), [Fe(III)Zn(II)(IPCPMP)(mpdp) $]\left[\mathrm{PF}_{6}\right](6)$, and $\left.[\mathrm{Fe}(\mathrm{III}) \mathrm{Cu}(\mathrm{II})(\mathrm{IPCPMP})(\mathrm{OAc})\}_{2}(\mu-\mathrm{O})\right]\left[\mathrm{PF}_{6}\right](7)$

\begin{tabular}{|c|c|c|c|c|c|c|c|c|c|}
\hline \multicolumn{2}{|c|}{2} & \multicolumn{2}{|l|}{3} & \multicolumn{2}{|l|}{4} & \multicolumn{2}{|l|}{6} & \multicolumn{2}{|l|}{7} \\
\hline $\mathrm{Zn} 1-\mathrm{O} 1$ & $2.137(2)$ & $\mathrm{Co} 1-\mathrm{O} 1$ & $2.075(2)$ & Ni1-O1 & $2.068(2)$ & $\mathrm{Zn} 1-\mathrm{O} 1$ & $2.1070(18)$ & $\mathrm{Cu} 1-\mathrm{O} 1$ & $1.909(3)$ \\
\hline $\mathrm{Zn} 1-\mathrm{O} 3$ & $2.088(3)$ & $\mathrm{Co} 1-\mathrm{O} 3$ & $2.085(2)$ & Ni1-O3 & $2.055(2)$ & $\mathrm{Zn} 1-\mathrm{O} 3$ & $2.1149(19)$ & $\mathrm{Cu} 1-\mathrm{O} 3$ & $1.935(3)$ \\
\hline $\mathrm{Zn} 1-\mathrm{O} 5$ & $2.061(3)$ & $\mathrm{Co} 1-\mathrm{O} 5$ & $2.088(2)$ & $\mathrm{Ni} 1-\mathrm{O} 5$ & $2.048(2)$ & $\mathrm{Zn} 1-\mathrm{O} 5$ & $2.088(2)$ & & \\
\hline $\mathrm{Zn} 1-\mathrm{O} 8$ & $2.089(3)$ & $\mathrm{Co} 1-\mathrm{O} 8$ & $2.079(2)$ & $\mathrm{Ni1}-\mathrm{O} 8$ & $2.069(2)$ & $\mathrm{Zn} 1-\mathrm{O} 7$ & $2.0270(19)$ & & \\
\hline $\mathrm{Zn} 1-\mathrm{N} 3$ & $2.282(3)$ & $\mathrm{Co} 1-\mathrm{N} 3$ & $2.268(3)$ & $\mathrm{Ni1}-\mathrm{N} 3$ & $2.210(3)$ & $\mathrm{Zn} 1-\mathrm{N} 3$ & $2.319(2)$ & $\mathrm{Cu} 1-\mathrm{N} 3$ & $2.022(4)$ \\
\hline $\mathrm{Zn} 1-\mathrm{N} 4$ & $2.115(3)$ & $\mathrm{Co} 1-\mathrm{N} 4$ & $2.100(2)$ & Ni1-N4 & $2.048(3)$ & $\mathrm{Zn} 1-\mathrm{N} 4$ & $2.120(2)$ & $\mathrm{Cu} 1-\mathrm{N} 4$ & $1.946(4)$ \\
\hline $\mathrm{Fe} 1-\mathrm{O} 1$ & $1.952(2)$ & $\mathrm{Fe} 1-\mathrm{O} 1$ & $1.972(2)$ & $\mathrm{Fe} 1-\mathrm{O} 1$ & $1.964(2)$ & $\mathrm{Fe} 1-\mathrm{O} 1$ & $1.9360(18)$ & $\mathrm{Fe} 1-\mathrm{O} 1$ & $2.047(3)$ \\
\hline $\mathrm{Fe} 1-\mathrm{O} 2$ & $1.971(3)$ & $\mathrm{Fe} 1-\mathrm{O} 2$ & $1.971(2)$ & $\mathrm{Fe} 1-\mathrm{O} 2$ & $1.976(2)$ & $\mathrm{Fe} 1-\mathrm{O} 2$ & $1.953(2)$ & $\mathrm{Fe} 1-\mathrm{O} 2$ & $2.072(3)$ \\
\hline $\mathrm{Fe} 1-\mathrm{O} 4$ & $1.932(3)$ & $\mathrm{Fe} 1-\mathrm{O} 4$ & $1.932(2)$ & $\mathrm{Fe} 1-\mathrm{O} 4$ & $1.934(2)$ & $\mathrm{Fe} 1-\mathrm{O} 4$ & $1.9961(18)$ & $\mathrm{Fe} 1-\mathrm{O} 6$ & $2.000(3)$ \\
\hline $\mathrm{Fe} 1-\mathrm{O} 6$ & $1.999(3)$ & $\mathrm{Fe} 1-\mathrm{O} 6$ & $1.994(2)$ & $\mathrm{Fe} 1-\mathrm{O} 6$ & $1.997(2)$ & $\mathrm{Fe} 1-\mathrm{O} 6$ & $2.0265(18)$ & $\mathrm{Fe} 1-\mathrm{O} 8$ & $1.7934(6)$ \\
\hline $\mathrm{Fe} 1-\mathrm{N} 1$ & $2.210(3)$ & $\mathrm{Fe} 1-\mathrm{N} 1$ & $2.210(2)$ & $\mathrm{Fe} 1-\mathrm{N} 1$ & $2.209(3)$ & $\mathrm{Fe} 1-\mathrm{N} 1$ & $2.198(2)$ & $\mathrm{Fe} 1-\mathrm{N} 1$ & $2.255(4)$ \\
\hline $\mathrm{Fe} 1-\mathrm{N} 2$ & $2.165(3)$ & $\mathrm{Fe} 1-\mathrm{N} 2$ & $2.162(2)$ & $\mathrm{Fe} 1-\mathrm{N} 2$ & $2.158(3)$ & $\mathrm{Fe} 1-\mathrm{N} 2$ & $2.144(2)$ & $\mathrm{Fe} 1-\mathrm{N} 2$ & $2.156(4)$ \\
\hline $\mathrm{Fe} 1-\mathrm{Zn} 1^{a}$ & $3.4556(6)$ & $\mathrm{Fe} 1-\mathrm{Co}^{a}$ & $3.4351(5)$ & $\mathrm{Fe} 1-\mathrm{Ni}^{a}$ & $3.4273(5)$ & $\mathrm{Fe} 1-\mathrm{Zn} 1^{a}$ & $3.4695(5)$ & $\mathrm{Fe} 1-\mathrm{Cu}^{a}$ & $3.2981(9)$ \\
\hline & & & & & & $\mathrm{Fe} 1-\mathrm{Zn} \# 1$ & $5.5799(5)$ & $\mathrm{Fe} 1-\mathrm{Fe} 1 \# 1^{a}$ & $3.5868(8)$ \\
\hline $\mathrm{Fe} 1-\mathrm{O} 1-\mathrm{Zn} 1$ & $115.27(11)$ & $\mathrm{Fe} 1-\mathrm{O} 1-\mathrm{Co} 1$ & $116.10(9)$ & $\mathrm{Fe} 1-\mathrm{O} 1-\mathrm{Ni} 1$ & $116.43(10)$ & $\mathrm{Fe} 1-\mathrm{O} 1-\mathrm{Zn} 1$ & $118.16(9)$ & $\mathrm{Cu} 1-\mathrm{O} 1-\mathrm{Fe} 1$ & $112.93(14)$ \\
\hline $\mathrm{N} 4-\mathrm{Zn} 1-\mathrm{N} 3$ & $80.54(12)$ & $\mathrm{N} 4-\mathrm{Co} 1-\mathrm{N} 3$ & $80.39(9)$ & N4-Ni1-N3 & $82.37(10)$ & $\mathrm{N} 4-\mathrm{Zn} 1-\mathrm{N} 3$ & $79.68(9)$ & $\mathrm{Fe} 1-\mathrm{O} 8-\mathrm{Fe} 1 \# 1$ & 180.0 \\
\hline $\mathrm{N} 4-\mathrm{Zn} 1-\mathrm{O} 1$ & $87.09(10)$ & $\mathrm{O} 1-\mathrm{Co} 1-\mathrm{N} 3$ & $89.03(8)$ & $\mathrm{N} 4-\mathrm{Ni1}-\mathrm{O} 1$ & $88.26(10)$ & $\mathrm{O} 1-\mathrm{Zn} 1-\mathrm{N} 3$ & $87.67(8)$ & $\mathrm{N} 4-\mathrm{Cu} 1-\mathrm{N} 3$ & $85.73(15)$ \\
\hline $\mathrm{O} 1-\mathrm{Zn} 1-\mathrm{N} 3$ & $88.00(10)$ & $\mathrm{O} 1-\mathrm{Co} 1-\mathrm{N} 4$ & $88.01(8)$ & $\mathrm{N} 4-\mathrm{Ni1}-\mathrm{O} 3$ & $90.05(11)$ & $\mathrm{O} 1-\mathrm{Zn} 1-\mathrm{N} 4$ & $89.62(8)$ & $\mathrm{O} 1-\mathrm{Cu} 1-\mathrm{N} 3$ & $95.92(14)$ \\
\hline $\mathrm{O} 3-\mathrm{Zn} 1-\mathrm{N} 3$ & $169.83(10)$ & $\mathrm{O} 1-\mathrm{Co} 1-\mathrm{O} 3$ & $92.89(8)$ & $\mathrm{N} 4-\mathrm{Ni1}-\mathrm{O} 8$ & $89.78(10)$ & $\mathrm{O} 1-\mathrm{Zn} 1-\mathrm{O} 3$ & $89.74(7)$ & $\mathrm{O} 1-\mathrm{Cu} 1-\mathrm{N} 4$ & $163.85(14)$ \\
\hline $\mathrm{O} 3-\mathrm{Zn} 1-\mathrm{N} 4$ & $89.38(12)$ & $\mathrm{O} 1-\mathrm{Co} 1-\mathrm{O} 5$ & $92.51(8)$ & $\mathrm{O} 1-\mathrm{Ni} 1-\mathrm{N} 3$ & $89.77(9)$ & $\mathrm{O} 3-\mathrm{Zn} 1-\mathrm{N} 3$ & $102.80(8)$ & $\mathrm{O} 1-\mathrm{Cu} 1-\mathrm{O} 3$ & $92.88(13$ \\
\hline $\mathrm{O} 3-\mathrm{Zn} 1-\mathrm{O} 1$ & $92.83(10)$ & $\mathrm{O} 1-\mathrm{Co} 1-\mathrm{O} 8$ & 177.31(9) & $\mathrm{O} 1-\mathrm{Ni} 1-\mathrm{O} 8$ & $177.56(10)$ & $\mathrm{O} 3-\mathrm{Zn} 1-\mathrm{N} 4$ & 177.41(9) & $\mathrm{O} 3-\mathrm{Cu} 1-\mathrm{N} 3$ & $156.95(15)$ \\
\hline $\mathrm{O} 3-\mathrm{Zn} 1-\mathrm{O} 8$ & $89.86(11)$ & $\mathrm{O} 3-\mathrm{Co} 1-\mathrm{N} 3$ & $170.77(9)$ & $\mathrm{O} 3-\mathrm{Ni1}-\mathrm{N} 3$ & $171.83(10)$ & $\mathrm{O} 5-\mathrm{Zn} 1-\mathrm{N} 3$ & $167.58(8)$ & $\mathrm{O} 3-\mathrm{Cu} 1-\mathrm{N} 4$ & $91.68(15)$ \\
\hline $\mathrm{O} 5-\mathrm{Zn} 1-\mathrm{N} 3$ & $102.87(11)$ & $\mathrm{O} 3-\mathrm{Co} 1-\mathrm{N} 4$ & $90.64(10)$ & $\mathrm{O} 3-\mathrm{Ni1}-\mathrm{O} 1$ & $93.03(9)$ & $\mathrm{O} 5-\mathrm{Zn} 1-\mathrm{N} 4$ & $88.75(9)$ & $\mathrm{N} 2-\mathrm{Fe} 1-\mathrm{N} 1$ & $76.33(14)$ \\
\hline $\mathrm{O} 5-\mathrm{Zn} 1-\mathrm{N} 4$ & $176.48(12)$ & $\mathrm{O} 3-\mathrm{Co} 1-\mathrm{O} 5$ & $85.75(10)$ & $\mathrm{O} 3-\mathrm{Ni1}-\mathrm{O} 8$ & $88.41(9)$ & $\mathrm{O} 5-\mathrm{Zn} 1-\mathrm{O} 1$ & $87.76(7)$ & $\mathrm{O} 1-\mathrm{Fe} 1-\mathrm{N} 1$ & $86.23(13)$ \\
\hline $\mathrm{O} 5-\mathrm{Zn} 1-\mathrm{O} 1$ & $92.15(10)$ & $\mathrm{O} 5-\mathrm{Co} 1-\mathrm{N} 3$ & 103.20(9) & $\mathrm{O} 5-\mathrm{Ni1}-\mathrm{N} 3$ & $101.07(10)$ & $\mathrm{O} 5-\mathrm{Zn} 1-\mathrm{O} 3$ & $88.72(8)$ & $\mathrm{O} 1-\mathrm{Fe} 1-\mathrm{N} 2$ & $88.89(13)$ \\
\hline $\mathrm{O} 5-\mathrm{Zn} 1-\mathrm{O} 3$ & $87.23(12)$ & $\mathrm{O} 5-\mathrm{Co} 1-\mathrm{N} 4$ & $176.37(10)$ & $\mathrm{O} 5-\mathrm{Ni1}-\mathrm{N} 4$ & $176.33(11)$ & $\mathrm{O} 7-\mathrm{Zn} 1-\mathrm{N} 3$ & $85.17(8)$ & $\mathrm{O} 1-\mathrm{Fe} 1-\mathrm{O} 2$ & $83.22(12)$ \\
\hline $\mathrm{O} 5-\mathrm{Zn} 1-\mathrm{O} 8$ & $91.17(11)$ & $\mathrm{O} 8-\mathrm{Co} 1-\mathrm{N} 3$ & $88.92(9)$ & $\mathrm{O} 5-\mathrm{Ni1}-\mathrm{O} 1$ & $93.02(9)$ & $\mathrm{O} 7-\mathrm{Zn} 1-\mathrm{N} 4$ & $93.43(8)$ & $\mathrm{O} 2-\mathrm{Fe} 1-\mathrm{N} 1$ & $87.60(14)$ \\
\hline $\mathrm{O} 8-\mathrm{Zn} 1-\mathrm{N} 3$ & $88.79(11)$ & $\mathrm{O} 8-\mathrm{Co} 1-\mathrm{N} 4$ & $89.93(9)$ & $\mathrm{O} 5-\mathrm{Ni1}-\mathrm{O} 3$ & $86.45(11)$ & $\mathrm{O} 7-\mathrm{Zn} 1-\mathrm{O} 1$ & $171.58(8)$ & $\mathrm{O} 2-\mathrm{Fe} 1-\mathrm{N} 2$ & $162.54(13)$ \\
\hline $\mathrm{O} 8-\mathrm{Zn} 1-\mathrm{N} 4$ & $89.75(11)$ & $\mathrm{O} 8-\mathrm{Co} 1-\mathrm{O} 3$ & $88.86(8)$ & $\mathrm{O} 5-\mathrm{Ni1}-\mathrm{O} 8$ & $89.03(10)$ & $\mathrm{O} 7-\mathrm{Zn} 1-\mathrm{O} 3$ & $87.54(8)$ & $\mathrm{O} 6-\mathrm{Fe} 1-\mathrm{N} 1$ & $75.69(13)$ \\
\hline $\mathrm{O} 8-\mathrm{Zn} 1-\mathrm{O} 1$ & $175.82(10)$ & $\mathrm{O} 8-\mathrm{Co} 1-\mathrm{O} 5$ & $89.66(9)$ & $\mathrm{O} 8-\mathrm{Ni1}-\mathrm{N} 3$ & $88.55(10)$ & $\mathrm{O} 7-\mathrm{Zn} 1-\mathrm{O} 5$ & $100.13(8)$ & $\mathrm{O} 6-\mathrm{Fe} 1-\mathrm{N} 2$ & $98.72(14)$ \\
\hline $\mathrm{N} 2-\mathrm{Fe} 1-\mathrm{N} 1$ & $78.09(11)$ & $\mathrm{N} 2-\mathrm{Fe} 1-\mathrm{N} 1$ & $78.07(9)$ & $\mathrm{N} 2-\mathrm{Fe} 1-\mathrm{N} 1$ & $78.32(10)$ & $\mathrm{N} 2-\mathrm{Fe} 1-\mathrm{N} 1$ & $74.59(8)$ & $\mathrm{O} 6-\mathrm{Fe} 1-\mathrm{O} 1$ & $157.99(12)$ \\
\hline $\mathrm{O} 1-\mathrm{Fe} 1-\mathrm{N} 1$ & $87.90(10)$ & $\mathrm{O} 1-\mathrm{Fe} 1-\mathrm{N} 1$ & $87.94(8)$ & $\mathrm{O} 1-\mathrm{Fe} 1-\mathrm{N} 1$ & $87.94(9)$ & $\mathrm{O} 1-\mathrm{Fe} 1-\mathrm{N} 1$ & $90.86(8)$ & $\mathrm{O} 6-\mathrm{Fe} 1-\mathrm{O} 2$ & $83.57(13)$ \\
\hline $\mathrm{O} 1-\mathrm{Fe} 1-\mathrm{N} 2$ & $84.81(10)$ & $\mathrm{O} 1-\mathrm{Fe} 1-\mathrm{N} 2$ & $84.63(8)$ & $\mathrm{O} 1-\mathrm{Fe} 1-\mathrm{N} 2$ & $84.78(9)$ & $\mathrm{O} 1-\mathrm{Fe} 1-\mathrm{N} 2$ & $165.45(9)$ & $\mathrm{O} 8-\mathrm{Fe} 1-\mathrm{N} 1$ & $168.15(11)$ \\
\hline $\mathrm{O} 1-\mathrm{Fe} 1-\mathrm{O} 2$ & $94.22(10)$ & $\mathrm{O} 1-\mathrm{Fe} 1-\mathrm{O} 6$ & $164.36(9)$ & $\mathrm{O} 1-\mathrm{Fe} 1-\mathrm{O} 2$ & $93.38(9)$ & $\mathrm{O} 1-\mathrm{Fe} 1-\mathrm{O} 2$ & $103.06(8)$ & $\mathrm{O} 8-\mathrm{Fe} 1-\mathrm{N} 2$ & $93.57(10)$ \\
\hline $\mathrm{O} 1-\mathrm{Fe} 1-\mathrm{O} 6$ & $164.32(11)$ & $\mathrm{O} 2-\mathrm{Fe} 1-\mathrm{N} 1$ & $92.42(9)$ & $\mathrm{O} 1-\mathrm{Fe} 1-\mathrm{O} 6$ & $164.44(10)$ & $\mathrm{O} 1-\mathrm{Fe} 1-\mathrm{O} 4$ & $93.85(7)$ & $\mathrm{O} 8-\mathrm{Fe} 1-\mathrm{O} 1$ & $99.92(9)$ \\
\hline $\mathrm{O} 2-\mathrm{Fe} 1-\mathrm{N} 1$ & $92.90(11)$ & $\mathrm{O} 2-\mathrm{Fe} 1-\mathrm{N} 2$ & $170.42(10)$ & $\mathrm{O} 2-\mathrm{Fe} 1-\mathrm{N} 1$ & $92.88(10)$ & $\mathrm{O} 1-\mathrm{Fe} 1-\mathrm{O} 6$ & $88.32(7)$ & $\mathrm{O} 8-\mathrm{Fe} 1-\mathrm{O} 2$ & 103.10(9) \\
\hline $\mathrm{O} 2-\mathrm{Fe} 1-\mathrm{N} 2$ & $170.97(12)$ & $\mathrm{O} 2-\mathrm{Fe} 1-\mathrm{O} 1$ & $93.94(8)$ & $\mathrm{O} 2-\mathrm{Fe} 1-\mathrm{N} 2$ & $171.05(11)$ & $\mathrm{O} 2-\mathrm{Fe} 1-\mathrm{N} 1$ & $165.12(8)$ & $\mathrm{O} 8-\mathrm{Fe} 1-\mathrm{O} 6$ & $100.18(9)$ \\
\hline $\mathrm{O} 2-\mathrm{Fe} 1-\mathrm{O} 6$ & $89.89(11)$ & $\mathrm{O} 2-\mathrm{Fe} 1-\mathrm{O} 6$ & $89.90(9)$ & $\mathrm{O} 2-\mathrm{Fe} 1-\mathrm{O} 6$ & $90.19(10)$ & $\mathrm{O} 2-\mathrm{Fe} 1-\mathrm{N} 2$ & $91.41(8)$ & & \\
\hline $\mathrm{O} 4-\mathrm{Fe} 1-\mathrm{N} 1$ & $167.80(10)$ & $\mathrm{O} 4-\mathrm{Fe} 1-\mathrm{N} 1$ & $167.46(9)$ & $\mathrm{O} 4-\mathrm{Fe} 1-\mathrm{N} 1$ & $167.87(10)$ & $\mathrm{O} 2-\mathrm{Fe} 1-\mathrm{O} 4$ & $92.91(8)$ & & \\
\hline $\mathrm{O} 4-\mathrm{Fe} 1-\mathrm{N} 2$ & $91.73(11)$ & $\mathrm{O} 4-\mathrm{Fe} 1-\mathrm{N} 2$ & $91.63(9)$ & $\mathrm{O} 4-\mathrm{Fe} 1-\mathrm{N} 2$ & $91.73(11)$ & $\mathrm{O} 2-\mathrm{Fe} 1-\mathrm{O} 6$ & $95.07(8)$ & & \\
\hline $\mathrm{O} 4-\mathrm{Fe} 1-\mathrm{O} 1$ & $97.96(11)$ & $\mathrm{O} 4-\mathrm{Fe} 1-\mathrm{O} 1$ & $98.30(9)$ & $\mathrm{O} 4-\mathrm{Fe} 1-\mathrm{O} 1$ & $98.14(10)$ & $\mathrm{O} 4-\mathrm{Fe} 1-\mathrm{N} 1$ & $91.37(8)$ & & \\
\hline $\mathrm{O} 4-\mathrm{Fe} 1-\mathrm{O} 2$ & $97.30(11)$ & $\mathrm{O} 4-\mathrm{Fe} 1-\mathrm{O} 2$ & $97.95(9)$ & $\mathrm{O} 4-\mathrm{Fe} 1-\mathrm{O} 2$ & $97.20(11)$ & $\mathrm{O} 4-\mathrm{Fe} 1-\mathrm{N} 2$ & $86.86(8)$ & & \\
\hline $\mathrm{O} 4-\mathrm{Fe} 1-\mathrm{O} 6$ & $96.51(10)$ & $\mathrm{O} 4-\mathrm{Fe} 1-\mathrm{O} 6$ & $96.17(9)$ & $\mathrm{O} 4-\mathrm{Fe} 1-\mathrm{O} 6$ & $96.43(10)$ & $\mathrm{O} 4-\mathrm{Fe} 1-\mathrm{O} 6$ & $171.04(8)$ & & \\
\hline $\mathrm{O} 6-\mathrm{Fe} 1-\mathrm{N} 1$ & $76.78(10)$ & $\mathrm{O} 6-\mathrm{Fe} 1-\mathrm{N} 1$ & $76.74(9)$ & $\mathrm{O} 6-\mathrm{Fe} 1-\mathrm{N} 1$ & $76.75(10)$ & $\mathrm{O} 6-\mathrm{Fe} 1-\mathrm{N} 1$ & $79.89(8)$ & & \\
\hline $\mathrm{O} 6-\mathrm{Fe} 1-\mathrm{N} 2$ & $88.76(10)$ & $\mathrm{O} 6-\mathrm{Fe} 1-\mathrm{N} 2$ & $89.06(9)$ & $\mathrm{O} 6-\mathrm{Fe} 1-\mathrm{N} 2$ & $89.36(10)$ & $\mathrm{O} 6-\mathrm{Fe} 1-\mathrm{N} 2$ & $88.87(8)$ & & \\
\hline
\end{tabular}

ascribed to the above-mentioned differences in bond lengths to the phenolic oxygen. These intermetal distances are slightly longer, but comparable to the $\mathrm{Fe}(\mathrm{III})-\mathrm{M}$ (II) distances crystallographically determined for heterodinuclear plant PAP enzymes $(3.1-3.3 \AA) .{ }^{27-29}$ These results can be compared to other heterodinuclear complexes of similar ligands with one phenolate and two acetate bridges that have been studied by other groups. The metal-metal distances in 2-4 are slightly shorter than in complexes containing terminal phenolate groups coordinated to $\mathrm{Fe}(\mathrm{III})$ (the BPBPMP ligand; $\mathrm{M}-\mathrm{M}=3.470(1)-3.510(9) \AA)^{56-60}$ 


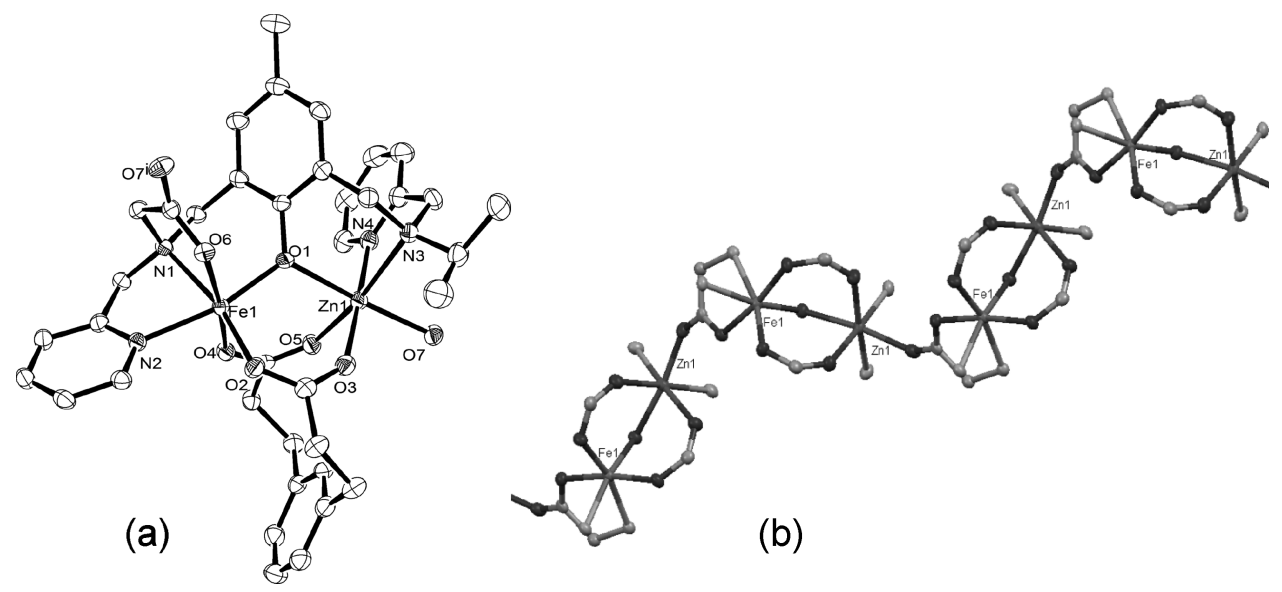

Figure 5. (a) ORTEP representation of the crystal structure of one monomer of [Fe(III)Zn(II)(IPCPMP)(mpdp)][PF 6 (6). (b) A Mercury plot of two repeating units in the polymeric network of 6 with only metals and atoms that are bridging and part of the polymeric backbone. All solvent and counterions have been omitted for clarity, and ellipsoids are drawn at 50\% probability.

but similar or slightly longer than complexes with only pyridyl donor moieties (and the two tertiary amines) in the dinucleating ligand $(3.378(8)-3.437(1) \AA) .{ }^{53,55,61}$ Further comparison to heterodinuclear complexes of BPBPMP ${ }^{56-60}$ show that the terminal phenolate-Fe(III) bond in the BPBPMP complexes are approximately $0.1 \AA$ shorter than the corresponding carboxylate-Fe(III) bonds in the IPCPMP complexes (O6-Fe1 in 2, 3, and 4, cf. Table 2), that occupy the same position trans to the bridging phenolate. The bond between $\mathrm{Fe}(\mathrm{III})$ and the bridging phenolate is accordingly slightly shorter $(0.05-0.03 \AA)$ in 2,3 , and 4 as compared to the BPBPMP complexes. It is obvious, however, that the nature of the exogenous bridge(s) strongly influences the intermetal distance between the metals when comparisons are made to complexes with similar phenolatebridging ligands as used here but different additional bridging moieties, for example, a hydroxide-bridged complex (Fe(III)$\mathrm{Zn}$ (II) 3.040(1) $\AA$ ) ${ }^{36}$ diphenylphosphate-bridged complexes (Fe(III)-Zn(II) $3.695(1)$ to $3.7402(7) \AA),{ }^{44,46,62}$ a molybdate-bridged complex (Fe(III)- $\mathrm{Zn}$ (II) $3.819(4) \AA)^{43}$ or complexes only containing the phenolate bridge and no exogenous bridge $\left(3.5821(12){ }^{63} 3.828(1)^{64} \AA\right)$.

It is clear from these structural comparisons that the mononuclear "synthon" 1 functions as a scaffold, inside which a divalent ion and two bridging carboxylates are easily fitted. ${ }^{49}$ In $2-4$, the sixth coordination site of the divalent metal is filled by a methanol ligand originating from the solvent. However, in the case of the formation of a dinuclear $\mathrm{Fe}(\mathrm{III}) \mathrm{Zn}$ (II) complex by reaction of $\mathbf{1}$ with $\mathrm{ZnCl}_{2}$ and meta-phenylene dipropionate (mpdp, Figure $2 \mathrm{~d}$ ), the crystal structure of the resultant complex [Fe(III) Zn(II)(IPCPMP)$(\mathrm{mpdp})]\left[\mathrm{PF}_{6}\right](6)$ reveals a heterodinuclear solid state polymer as shown in Figure 5. Crystallographic data are summarized in Table 1, and relevant bond distances and angles are listed in Table 2. The repeating dinuclear units are connected via the carboxylate functionality of the IPCPMP ligand that is coordinated to the $\mathrm{Fe}$ (III) and that bridges in a syn, anti- $\mu_{1,3}$ manner to the $\mathrm{Zn}$ at the "open" site that is occupied by solvent in $\mathbf{2 - 4}$. The bond distances are only slightly changed as compared to 2 , and the metal-metal distance within a repeating dinuclear unit is Fe1-Zn1 3.4695(5) $\AA$ and between two repeating units Fe1-Zn\#1 5.5799(5) Å. In fast atom bombardment (FAB) mass spectrometry of this complex only the dinuclear complex $[\mathrm{Fe}(\mathrm{III}) \mathrm{Zn}(\mathrm{II})(\mathrm{IPCPMP})(\mathrm{mpdp})]^{+}$is observed.
The above-mentioned divalent metals readily accommodate (distorted) octahedral geometries, but $\mathrm{Cu}$ (II) is well-known to prefer strong tetragonal distortion from an octahedral geometry or square planar coordination. Accordingly, the reaction of the mononuclear "synthon" 1 with $\mathrm{Cu}(\mathrm{II})$ acetate monohydrate, using method A (vide supra and Experimental Section), gave $\left.[\mathrm{Fe}(\mathrm{III}) \mathrm{Cu}(\mathrm{II})(\mathrm{IPCPMP})(\mathrm{OAc})\}_{2}(\mu-\mathrm{O})\right]\left[\mathrm{PF}_{6}\right]$ (7). The crystal structure of 7 was determined, and the molecular structure of the complex is shown in Figure 6; crystallographic data are summarized in Table 1, and relevant bond distances and angles are listed in Table 2. Complex 7 is tetranuclear, consisting of two dinuclear moieties that contains two $\mu$-oxido bridged octahedral $\mathrm{Fe}$ (III) ions and two $\mathrm{Cu}(\mathrm{II})$ ions in a distorted square planar geometry. The two heterodinuclear parts are related by inversion symmetry with the center of inversion located on the bridging oxido group. Coordination of the copper by only four donors nominally leaves one vacant coordination site on the iron ion because of the absence of a (second) carboxylate bridge in the dinuclear moiety; this coordination site is filled by the $\mu$-oxido ligand that most likely is formed from residual water in the solvent (methanol). Each Fe(III) ion is thus in an octahedral $\mathrm{N}_{2} \mathrm{O}_{4}$ environment bridged to a $\mathrm{Cu}$ (II) ion through the phenolate of the ligand and one syn,syn- $\mu_{1,3}$-acetate bridge. With only four donors $\left(\mathrm{N}_{2} \mathrm{O}_{2}\right)$, the bonds to the $\mathrm{Cu}$ (II) ions are shorter by more than $0.1 \AA$ (average $\mathrm{Cu}-\mathrm{X}=1.953 \AA$ ) compared to those for the divalent metals in $2-4$. In contrast, all bonds to the $\mathrm{Fe}$ (III) are longer (average $\mathrm{Fe}-\mathrm{X}=2.054 \AA$ ) than in $2-4$ with the exception of the $\mathrm{Fe}-\mathrm{O}_{\text {oxido }}$ bond $(1.7934(6) \AA)$. The $\mathrm{Fe}(\mathrm{III})-\mathrm{O}-\mathrm{Fe}$ (III) angle is $180^{\circ}$, and the distance between them is $3.5868(8) \AA$. The $\mathrm{Fe}(\mathrm{III})-\mathrm{Cu}$ (II) distance (3.2981(9) $\AA$ ) is shorter than the $\mathrm{Fe}(\mathrm{III})-\mathrm{M}$ (II) distance in either 2, 3, or 4 mainly because of the very short bond between the $\mathrm{Cu}(\mathrm{II})$ and the phenolic oxygen, since the corresponding $\mathrm{Fe}(\mathrm{III})-\mathrm{O}_{\text {phenolate }}$ distance $(2.047(3) \AA)$ is actually longer in 7 than in $2-4$ and analogous complexes of the BPBPMP ligand (vide supra). Similar $\mathrm{Fe}-\mathrm{O}-\mathrm{Fe}$-bridged tetranuclear (dimer of dimer) structures, as in $7(\mathrm{FeCu})$, has been observed previously with heterodinuclear complexes of macrocyclic bis-phenolato-bridging ligands (Figure 2c) ${ }^{65,66}$ and oxido-bridged dinuclear Fe(III) complexes are quite common. ${ }^{67}$ Typical $\mathrm{Fe}-\mathrm{O}_{\text {oxido }}$ and $\mathrm{Fe}-\mathrm{Fe}$ distances are $1.734(1)-1.7816(7) \AA$ and $3.468-3.563(1) \AA$, respectively, for monobridged $\mu$-oxido complexes with an 

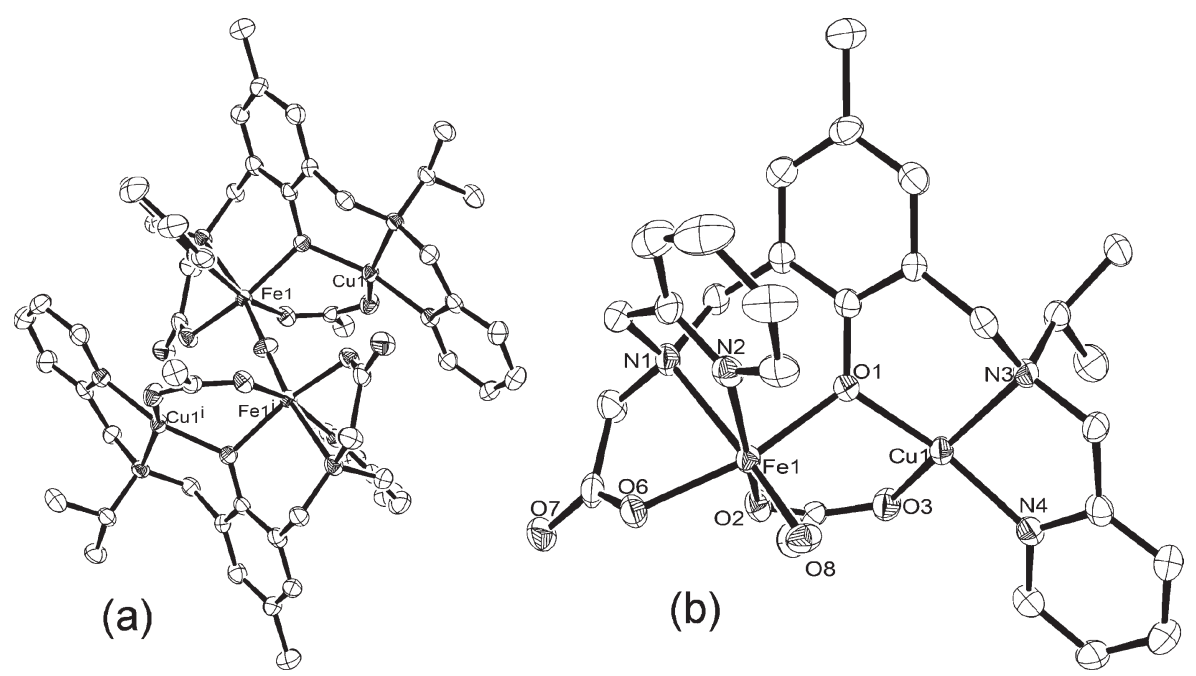

Figure 6. ORTEP representations of the crystal structure of $\left.[\mathrm{Fe}(\mathrm{III}) \mathrm{Cu}(\mathrm{II})(\mathrm{IPCPMP})(\mathrm{OAc})\}_{2}(\mu-\mathrm{O})\right]\left[\mathrm{PF}_{6}\right]$ (7). All solvent molecules and counterions have been omitted for clarity, and the ellipsoids are drawn at $50 \%$ probability. In (a) the complete tetranuclear structure is shown, and in (b) only the dinuclear $\mathrm{FeCu}$ part of the structure is displayed.

$\mathrm{Fe}-\mathrm{O}-\mathrm{Fe}$ angle of $180^{\circ}$, indicating that the corresponding distances in complex 7 are relatively long. Biswas et al. ${ }^{65}$ and Dutta et al., ${ }^{66}$ who have isolated similar $\mu$-oxido bridged dimers, observed a linear bridge for a $\mathrm{Fe}(\mathrm{III})-\mathrm{Zn}$ (II) complex and bent bridges for a $\mathrm{Fe}(\mathrm{III})-\mathrm{Co}$ (III) complex with $\mathrm{Fe}-\mathrm{Fe}$ distances of 3.561(1), 3.564(1), and 3.549(1) $\AA$ for $\mathrm{Zn}(\mathrm{II}) \mathrm{Fe}(\mathrm{III})-\mathrm{O}-\mathrm{Fe}-$ (III) $\mathrm{Zn}(\mathrm{II}), \mathrm{Co}(\mathrm{III}) \mathrm{Fe}(\mathrm{III})-\mathrm{O}-\mathrm{Fe}(\mathrm{III}) \mathrm{Co}(\mathrm{III})$ and a $\mathrm{Fe}-$ (III) $-\mathrm{O}-\mathrm{Fe}(\mathrm{III})$ dimers, respectively.

Finally, although not all structures discussed above are strictly comparable, it should be noted that the pyridyl and carboxylate donors of IPCPMP occupy different positions in relation to the other coordinating groups in different complexes. In mononuclear 1 and in 6 (FeZn-mpdp), the pyridyl group on the carboxylate side of IPCPMP (binding to Fe(III)) is trans to the bridging phenolate group while in 2 ( $\mathrm{FeZn}), 3$ ( $\mathrm{FeCo}), 4(\mathrm{FeNi})$, and $7(\mathrm{FeCu})$ the carboxylate on this side binds trans to the phenolate, and the pyridyl is trans to one of the bridging acetates. In complex 7, the pyridyl on the 2-propyl side (binding to $\mathrm{Cu}(\mathrm{II}))$ is trans to the phenolate while for $\mathbf{2 - 4}$ and 6 it is trans to one of the bridging acetates. Electronic effects appear to be of minor importance for the positions of the donor groups. In $\mathbf{1}$, the cis position of the carboxylate in relation to the central phenolate moiety of the ligand may be due to favorable hydrogen bonding between the carboxylate (O1) and the nitrogen $(\mathrm{N} 1)$ of the second, protonated, pyridyl moiety of the ligand (cf. Figure 3). In 7 , restraints caused by the square planar geometry at the $\mathrm{Cu}$ (II) force the phenolate oxygen, the tertiary nitrogen, and the pyridyl nitrogen to be in one plane, thus positioning the pyridyl trans to the phenolate. It is rational that the bridging oxido ligand is trans to the weak $\mathrm{Fe}-\mathrm{N}$ bond of the tertiary nitrogen. In 6 , packing effects in the solid state may favor one conformer in the extended polymeric relative to the other.

We have not been able to determine whether different conformers exist in solution and, if so, how or if they interconvert between each other. If the solid state structure of $\mathbf{1}$ (Figure 3 ) is the only form found in solution, then a ligand rearrangement is needed to form $\mathbf{2 - 5}$. This would probably require the dissociation of the phenolate and subsequent formation of a new phenolate-Fe(III) bond in trans position relative to the carboxylate. In 1, an octahedral rearrangement by a Bailar or Ray-Dutt twist is in principle possible, while in the dinuclear assemblies this would probably require that the same twist occurs on both metals at the same time since the plane of the phenolate aromatic ring generally prefers being significantly tilted relative to the plane formed by the two metals and the phenolate oxygen O1 (2: $51.89^{\circ}, 3: 52.18^{\circ}, 4: 51.72^{\circ}, 5: 50.83^{\circ}$ 6: $\left.52.53^{\circ}\right)$. Although this type of tilt is rarely discussed, it appears to be present for most complexes with this type of 1,3-methyleneamine phenolate ligands. ${ }^{53,55,68-70}$ The tilt angle is very small $\left(17.40^{\circ}\right)$ for the hydroxido bridged $\mathrm{Fe}(\mathrm{III}) \mathrm{Zn}$ (II) complex reported by Neves et al. which has an unusually short distance between the metal ions. ${ }^{36}$ The tilt of the phenolate relative to the intermetal axis induces skew chirality, and there are four stereogenic centers in the general heterodinuclear molecule (the two metals and the two tertiary nitrogens). A number of diastereomers are thus in principle possible, and the complexes crystallize as racemates of two enantiomers with $S, S$ - and $R, R$-configurations at the tertiary amines (cf. Figure 4).

IR Spectroscopy. The endogenous carboxylate donor of the ligand IPCPMP makes infrared spectroscopy a useful tool to study the complexation behavior of the ligand in both solid state and solution. Especially the difference in energy for the antisymmetric and the symmetric stretch $\left(\Delta v=v_{\text {anti }}-v_{\text {sym }}\right)$ of metal carboxylates has been used to evaluate whether they are coordinated in a bridging or monodentate mode $\left(>200 \mathrm{~cm}^{-1}\right.$ monodentate; $\leq 180 \mathrm{~cm}^{-1}$ bridging; $\ll 180 \mathrm{~cm}^{-1}$ chelating). ${ }^{71}$ This can be used to assign the peaks in the FTIR spectra of complexes $2(\mathrm{FeZn}), 3(\mathrm{FeCo}), 4(\mathrm{FeNi}), \mathbf{5}(\mathrm{FeMn})$, and 7 ( FeCu) in $\mathrm{KBr}$ (Figure 7a) and to relate these to structural features in both solid state and solution.

The FTIR spectra for $\mathbf{2} \mathbf{- 4}$ are very similar, as expected because of their almost identical structures in the solid state. The striking similarity of the IR spectrum of 5 to those of $2-4$ strongly indicates that the general structure of $\mathbf{5}$ is identical to those of the other three complexes. The IR resonances for $\mathbf{2 - 5}$ can be assigned by comparing their relationships in terms of energy (wavenumber) and intensities. For $\mathbf{2}-\mathbf{5}$ the symmetric $\left(v_{\text {sym }}\right)$ and antisymmetric $\left(v_{\text {anti }}\right)$ vibrations of the bridging 

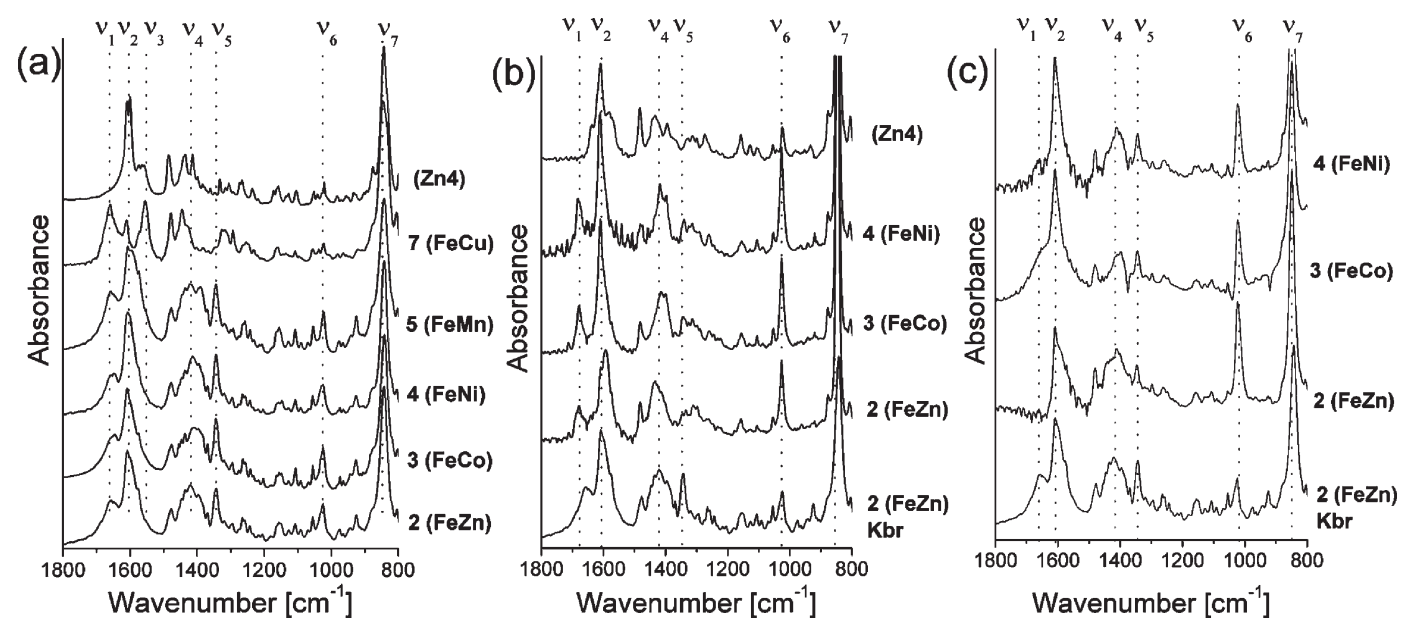

Figure 7. Fourier transform IR spectra of complexes $\left[\mathrm{Fe}(\mathrm{III}) \mathrm{M}(\mathrm{II})(\mathrm{IPCPMP})(\mathrm{OAc})_{2}\left(\mathrm{CH}_{3} \mathrm{OH}\right)\right]\left[\mathrm{PF}_{6}\right](\mathrm{M}=\mathrm{Zn}(2), \mathrm{Co}(3), \mathrm{Ni}(4), \mathrm{Mn}(5))$, $\left.[\mathrm{Fe}(\mathrm{III}) \mathrm{Cu}(\mathrm{II})(\mathrm{IPCPMP})(\mathrm{OAc})\}_{2}(\mu-\mathrm{O})\right]\left[\mathrm{PF}_{6}\right](7)$, and $\left[\left\{\mathrm{Zn}_{2}(\mathrm{IPCPMP})(\mathrm{OAc})\right\}_{2}\right]\left[\mathrm{PF}_{6}\right](\mathrm{Zn} 4)$ in $\mathrm{KBr}(\mathrm{a})$. Solution FTIR of 2, 3, 4 and $\mathrm{Zn} 440 \mathrm{mM}$

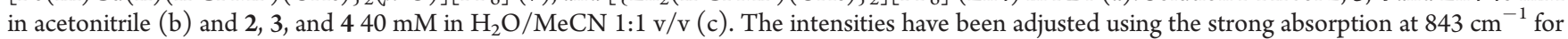
$\mathrm{PF}_{6}{ }^{-}$as internal standard. The spectra are numbered after their corresponding complexes. In the middle and bottom graphs the spectrum of $\mathbf{2}$ in $\mathrm{KBr}$ has been added as a reference.

acetates are assigned to the bands $v_{4}$ and $v_{2}$ at 1419 and $1608 \mathrm{~cm}^{-1}$, respectively, based on their intensities and similarity to literature data. ${ }^{71}$ The difference between $v_{\text {anti }}$ and $v_{\text {sym }}(\Delta v=$ $\left.v_{\text {anti }}-v_{\text {sym }}\right)$ is $189 \mathrm{~cm}^{-1}$, which is close to the ionic value of acetates, characteristic for bridging carboxylate ligands. ${ }^{71} \mathrm{Com}-$ parison of these symmetric $\left(\sim 1400 \mathrm{~cm}^{-1}, v_{4}\right)$ and antisymmetric stretches $\left(\sim 1600 \mathrm{~cm}^{-1}, v_{2}\right)$, of the bridging carboxylates for $2(\mathrm{FeZn}), 3(\mathrm{FeCo}), 4(\mathrm{FeNi})$, and $\mathbf{5}(\mathrm{FeMn})$ reveal only minor differences despite their bridging between different metals.

The smaller and somewhat broadened resonance at $1650 \mathrm{~cm}^{-1}$ $\left(v_{1}\right)$ probably originates from the antisymmetric stretch of the terminal and monodentate carboxylate of the IPCPMP ligand. The intensity of this resonance relative to that at $1608 \mathrm{~cm}^{-1}\left(v_{2}\right)$ is in agreement with the ratio $(2: 1)$ of bridging versus terminal carboxylates in the complex. This assignment is indirectly confirmed by comparison to the IR spectrum of the tetranuclear zinc complex $\left[\left\{\mathrm{Zn}_{2}(\mathrm{IPCPMP})(\mathrm{OAc})\right\}_{2}\right]\left[\mathrm{PF}_{6}\right]^{47}$ which does not have any terminal monodentate carboxylate, and does not show any similar IR resonance, except in solution where dissociation is expected to occur. $^{72}$ The symmetric band of this monodentate carboxylate can also be assigned to $1342 \mathrm{~cm}^{-1}\left(v_{5}\right)$ by comparing to $\left[\left\{\mathrm{Zn}_{2}(\mathrm{IPCPMP})(\mathrm{OAc})\right\}_{2}\right]\left[\mathrm{PF}_{6}\right]$, which does not have any intense peak in this region. This assignement yields $\Delta v=313 \mathrm{~cm}^{-1}$, in line with what is expected for a monodentate carboxylate.

The IR spectrum of $7(\mathrm{FeCu})$ is quite different from $2-4$ but can be similarly assigned by comparison to the crystal structure. It displays somewhat broadened peaks at $1660 \mathrm{~cm}^{-1}\left(v_{1}\right)$ and $1321 \mathrm{~cm}^{-1}\left(v_{6}\right)$ with $\Delta v=339 \mathrm{~cm}^{-1}$, corresponding well to monodentate coordinated carboxylates and peaks at 1556 (right of $\left.v_{2}\right)$ and $1444 \mathrm{~cm}^{-1}\left(v_{4}\right)$ with $\Delta v=112 \mathrm{~cm}^{-1}$, which is within limits for bridging acetates. The relative intensities of the resonances are in agreement with the structure of 7 . No stretches corresponding to $\mu$-oxido-diFe(III) vibrations ${ }^{67}$ have been observed. They are likely concealed by the very strong absorptions of the hexafluorophosphate anion ( $v_{8}$ and others) in this region.

When the complexes $2(\mathrm{FeZn}), 3(\mathrm{FeCo})$, and $4(\mathrm{FeNi})$ are dissolved in acetonitrile, the peak at $1650 \mathrm{~cm}^{-1}\left(v_{1}\right)$ for all complexes in $\mathrm{KBr}$ sharpens up and shifts to higher wavenumbers (1678, 1678, and $1682 \mathrm{~cm}^{-1}$ for $2,3,4$, respectively, $v_{1}$
Figure $7 \mathrm{~b})$. The fact that this stretch is virtually the same for complexes $\mathbf{2}-\mathbf{4}$ is an indication that the stretch originates from the terminal carboxylate bound to the $\mathrm{Fe}(\mathrm{III})$ ion. This also suggests that metal migration in the complex from one side of the phenolate to another does not occur in acetonitrile solution within the detection limits of this FTIR experiment. The broad appearance of this peak in the solid state is probably due to inhomogeneous broadening, and the various weak interactions that cause this broadening are removed in solution.

Because of the low solubility of the complexes in water, all reactivity studies were performed in a water/acetonitrile solution $(1: 1 \mathrm{v} / \mathrm{v}$, vide infra). Therefore, this solvent mixture was also used in the FTIR experiments. The analysis is complicated by the strong hydrogen-bonding capabilities of water, which can interact strongly with heteroatoms such as the oxygens of the carboxylate groups. The major change in the IR spectra when the complexes are dissolved in the above-mentioned solvent mixture (Figure $7 \mathrm{c}$ ) is that the $v_{\text {anti }}$ peak at $1678 \mathrm{~cm}^{-1}\left(v_{1}\right)$ completely disappears in the case of $\mathbf{2}$ and for $\mathbf{3}$ and $\mathbf{4}$ it broadens and shifts to lower wavenumbers, almost disappearing behind the resonance at $1609 \mathrm{~cm}^{-1}$. This could be explained by interaction of the terminal carboxylate of the ligand with water through hydrogen bonding, a form of pseudobridging. In previous studies, absences of large $\Delta v$ in solution in cases where monodentate acetate coordination to metals have been determined by crystallography have been explained by pseudobridging to hydrogens in the structure. ${ }^{71}$ A similar explanation for complexes in protic solvents seems viable. Another possible explanation is that the endogenous monodentate carboxylate of IPCPMP is bridging to other metals also in solution in the case of complex 2; this could then be the reason for the peak at $1678 \mathrm{~cm}^{-1}$ disappearing completely for $\mathbf{2}$ but not for $\mathbf{3}$ and $\mathbf{4}$. The spectra of $\mathbf{3}$ and $\mathbf{4}$ in water/acetonitrile are, however, still similar to their spectra in the solid state $(\mathrm{KBr})$ and acetonitrile solution, except for the two peaks at about 1678 and $1313 \mathrm{~cm}^{-1}$ (vide supra). This might suggest that the structures of these complexes remain intact in solution at close to neutral $\mathrm{pH}$.

The peaks at $1026 \mathrm{~cm}^{-1}\left(v_{7}\right)$ and $1478 \mathrm{~cm}^{-1}\left(v_{3}\right)$ are assigned to rocking vibration of the acetate methyl groups ${ }^{73}$ and aromatic 

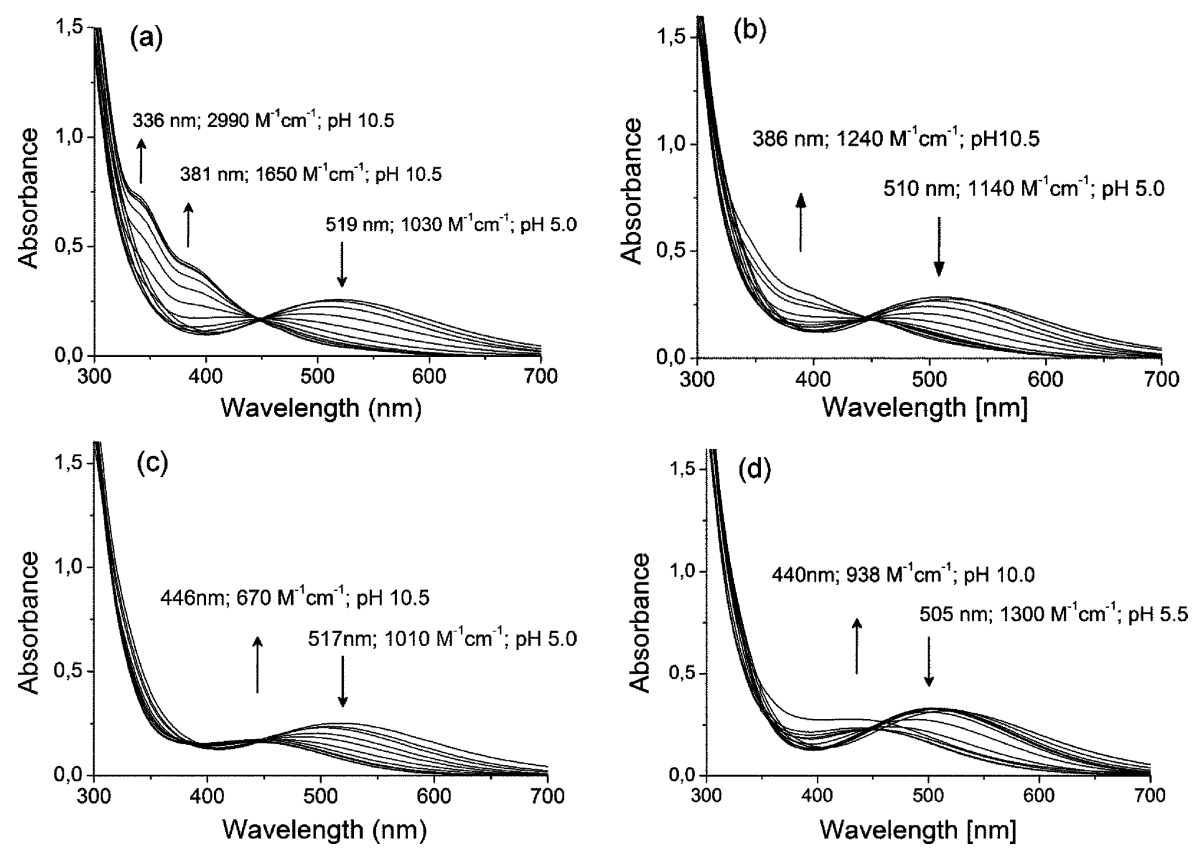

Figure 8. Dependence on $\mathrm{pH}$ of the spectra of $\left[\mathrm{Fe}(\mathrm{III}) \mathrm{M}(\mathrm{II})(\mathrm{IPCPMP})(\mathrm{OAc})_{2}\left(\mathrm{CH}_{3} \mathrm{OH}\right)\right]\left[\mathrm{PF}_{6}\right](\mathrm{M}=\mathrm{Zn}$ (2), Co (3), Ni (4), Mn (5). The arrows indicate the decrease and increase in intensity of specific bands when going from $\mathrm{pH} 5$ to 10.5 in steps of 0.5 .

$\mathrm{C}=\mathrm{C}$ stretches, respectively. These bands, however, do not change for any of the complexes or conditions discussed above.

Mass Spectrometry. To further elucidate the nature of the heterodinuclear complexes in solution, mass spectrometric measurements were performed. Electrospray ionization mass spectra (ESI-MS) of 2 (FeZn), 3 (FeCo), 4 (FeNi), 5 (FeMn), and 7 $(\mathrm{FeCu})$ in acetonitrile solutions display peaks with $\mathrm{m} / \mathrm{z}$ values and isotope patterns corresponding to the formulation $\left[\mathrm{Fe}(\mathrm{III}) \mathrm{M}(\mathrm{II})(\mathrm{IPCPMP})(\mathrm{OAc})_{2}\right]^{+}(\mathrm{M}(\mathrm{II})=\mathrm{Zn}, \mathrm{Co}, \mathrm{Ni}$, and $\mathrm{Mn}$, respectively). For complex 7, a cluster of peaks at $m / z 632$ corresponding to the dicationic $[\{\mathrm{Fe}(\mathrm{III}) \mathrm{Cu}(\mathrm{II})(\mathrm{IPCPMP})$ $\left.(\mathrm{OAc})\}_{2}(\mathrm{O})\right]^{2+}$ (mass $=1264$ a.m.u. $)$ is observed although the isotope pattern is distorted due the use of unit resolution. A very weak peak corresponding to $[\{\mathrm{Fe}(\mathrm{III}) \mathrm{Cu}(\mathrm{II})(\mathrm{IPCPMP})$ $\left.(\mathrm{OAc})\}_{2}(\mathrm{O})\left(\mathrm{PF}_{6}\right)\right]^{+}$with $\mathrm{m} / z$ of 1409 and correct isotope pattern could, however, be detected.

Upon dissolving these complexes in water/acetonitrile 1:1 (v/ v) the mass-spectra change considerably. For 2 and 4, peaks corresponding to $[\mathrm{Fe}(\mathrm{III}) \mathrm{M}(\mathrm{II})(\mathrm{IPCPMP})(\mathrm{OAc})(\mathrm{OH})]^{+}(\mathrm{m} /$ $z=642$ and 636 for $\mathrm{Zn}(\mathrm{II})$ and $\mathrm{Ni}(\mathrm{II})$, respectively) and $[\mathrm{Fe}(\mathrm{III}) \mathrm{M}(\mathrm{II})(\mathrm{IPCPMP})(\mathrm{O})]^{+}(m / z=582$ and 576 for $\mathrm{Zn}$ (II) and $\mathrm{Ni}(\mathrm{II})$, respectively) occur. Both these species are also observed for 3 as well as a peak corresponding to $\left[\mathrm{Fe}(\mathrm{III}) \mathrm{Co}(\mathrm{II})(\mathrm{IPCPMP})(\mathrm{OH})_{2}\right]^{+}(m / z=595)$. For all three complexes, the spectra also contain a peak for the mononuclear $\mathrm{Fe}(\mathrm{III})$ complex $[\mathrm{Fe}(\mathrm{III})(\mathrm{IPCPMP})]^{+}(\mathrm{m} / z=502)$. However, no peaks corresponding to either homodinuclear complexes or mononuclear complexes of the divalent metal ion are observed, indicating that the $\mathrm{Fe}(\mathrm{III})$ is tightly bound, probably on the carboxylate side, while the divalent metal ion is more labile under these conditions. Indeed, only the mononuclear $[\mathrm{Fe}(\mathrm{III})(\mathrm{IPCPMP})]^{+}$complex is observed for complex $\mathbf{5}$ in water/acetonitrile solution $(1: 1 \mathrm{v} / \mathrm{v})$. The dissociation of manganese from heterodinuclear $\mathbf{5}$ is in line with the relatively weak binding generally observed for (high spin) $\mathrm{Mn}$ (II) that is due to its low charge-to-radius ratio and lack of ligand field stabilization energy. ${ }^{74}$ It should be noted that the $\mathrm{pH}$ of these water/ acetonitrile solutions was not controlled but are assumed to be within the $5-7 \mathrm{pH}$ range. Adjusting the $\mathrm{pH}$ of the solution of 5 to $\sim \mathrm{pH} 9$ using a dilute $\mathrm{NaOH}$ solution yields a range of peaks but several can be related to $\mathrm{Fe}$ (III) $\mathrm{Mn}$ (II) species of the ligand (e.g., $[\mathrm{Fe}(\mathrm{III}) \mathrm{Mn}(\mathrm{II})(\mathrm{IPCPMP})(\mathrm{OAc})(\mathrm{OH})]^{+} m / z=633$, [Fe(III)$\left.\mathrm{Mn}(\mathrm{II})(\mathrm{IPCPMP})(\mathrm{OH})_{2}\right]^{+} m / z=591$, and [Fe(III)Mn(II)$(\mathrm{IPCPMP})(\mathrm{O})]^{+} m / z=573$. Because of experimental difficulties, the other complexes could not be studied under the same conditions.

In $\mathrm{FAB}+$ mass spectra of 2 left in $\mathrm{H}_{2} \mathrm{O}$ /acetonitrile solution over several hours, peaks corresponding to dinuclear $\mathrm{Zn}$ complexes can be observed. The relative intensities of these peaks increase upon treatment with base (triethyl amine). This indicates that decomposition of the heterodinuclear complexes over extended periods of time at high $\mathrm{pH}$ cannot be excluded. In contrast to complexes 2-4, only a minute peak for the mononuclear complex is observed $(<3 \%)$ for $7(\mathrm{FeCu})$ in water/acetonitrile solution. Three major peaks with $m / z$ and isotope patterns corresponding to $[\mathrm{Fe}(\mathrm{III}) \mathrm{Cu}-$ (II) $($ IPCPMP $\left.)(\mathrm{OH})_{2}\right]^{+}(m / z=599),[\mathrm{Fe}(\mathrm{III}) \mathrm{Cu}(\mathrm{II})(\mathrm{IPCPMP})$ $(\mathrm{O})]+(m / z=581)$, and $\left[\{\mathrm{Fe}(\mathrm{III}) \mathrm{Cu}(\mathrm{II})(\mathrm{IPCPMP})(\mathrm{OH})\}_{2^{-}}\right.$ $(\mathrm{O})]^{2+}(\mathrm{m} / z=1180 / 2=590)$ are shown.

For all acetate-bridged complexes at least partial substitution of these exogenous carboxylate bridges is to be expected in aqueous solution because of their well documented lability. ${ }^{75} \mathrm{It}$ should be noted, however, that several of the detected species are degradation products due to the ionization process. For example, the species $\mathrm{Fe}(\mathrm{III}) \mathrm{M}(\mathrm{II})(\mathrm{IPCPMP})(\mathrm{O})]^{+}$observed in the spectra of 2, 3, and 4 in aqueous solution could be generated by loss of a proton from a coordinated hydroxide or from $\mathrm{Fe}(\mathrm{III}) \mathrm{M}$ (II)(IPCPMP $)(\mathrm{OAc})(\mathrm{OH})]^{+}$by loss of acetic acid.

Electronic Spectroscopy. The strong absorption of the phenolate-to-Fe(III) charge transfer transition is a characteristic feature of both the purple acid phosphatases and the complexes in this study. It is a valuable spectroscopic tool to probe changes that occur especially in the Fe(III) coordination sphere. The 

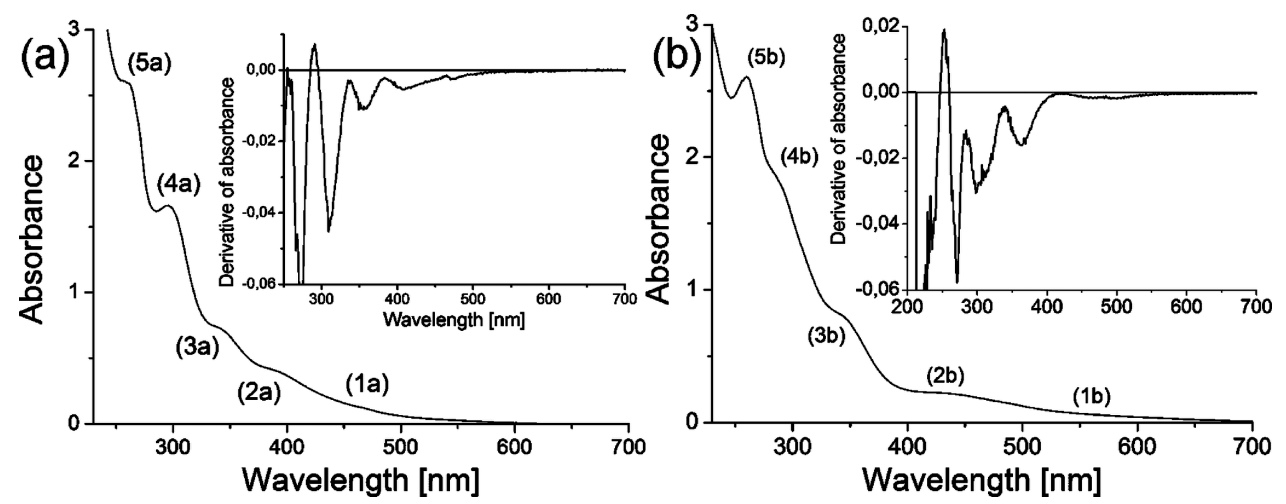

Figure 9. $\mathrm{UV}$-vis spectrum of (a) $\left[\mathrm{Fe}(\mathrm{III}) \mathrm{Zn}(\mathrm{II})(\mathrm{IPCPMP})(\mathrm{OAc})_{2}\left(\mathrm{CH}_{3} \mathrm{OH}\right)\right]\left[\mathrm{PF}_{6}\right]$ (2) at $\mathrm{pH} 10,0.25 \mathrm{mM}$ in acetonitrile/water $1: 1$, and (b) $[\mathrm{Fe}(\mathrm{III}) \mathrm{Cu}(\mathrm{II})(\mathrm{IPCPMP})(\mathrm{OAc})\}_{2}(\mu$-O) $]\left[\mathrm{PF}_{6}\right](7), 0.1 \mathrm{mM}$ in acetonitrile. The inset displays the derivative of the absorbance vs the wavelength to more clearly display the shoulders present in the spectra.

$\mathrm{UV}$ - vis spectra of $\mathbf{2}(\mathrm{FeZn}), \mathbf{3}$ ( $\mathrm{FeCo}), \mathbf{4}(\mathrm{FeNi})$, and $\mathbf{5}(\mathrm{FeMn})$ were collected at several different $\mathrm{pHs}$ using the buffered solutions for the reactivity studies with HPNP (vide infra) before adding the substrate. All spectra (Figure 8) change smoothly displaying isosbestic points, but there are differences between the complexes. Complex 2 (FeZn) appears to be completely converted to a new species at $\mathrm{pH}$ 9.5. This species displays absorptions characteristic of oxido-to-Fe(III) dimer charge transfer interactions $^{67}$ at $336 \mathrm{~nm}$ (3a in Figure 9; $2990 \mathrm{M}^{-1} \mathrm{~cm}^{-1}$ ) and $381 \mathrm{~nm}\left(3 \mathrm{~b} ; 1650 \mathrm{M}^{-1} \mathrm{~cm}^{-1}\right)$ as seen in Figure 9a. In principle, three transitions are possible: $\mathrm{p}_{z} \rightarrow \mathrm{Fe} \mathrm{d}_{z^{2}}$, which usually is concealed by other strong absorptions below $300 \mathrm{~nm}$ and $\mathrm{p}_{x}$ and $\mathrm{p}_{y} \rightarrow \mathrm{Fe} \mathrm{d}_{x z}$ and $\mathrm{d}_{y z}$. For a linear bridge between the two $\mathrm{Fe}(\mathrm{III})$ ions, the $\mathrm{p}_{x}$ and $\mathrm{p}_{y}$ transitions are degenerate and only one band is observed between 300 and $500 \mathrm{~nm}$. When the $\mathrm{Fe}-\mathrm{O}-\mathrm{Fe}$ bridge is bent, the two transitions split, and two bands are observed. ${ }^{67,76}$ This could indicate that the species formed from 2 at high $\mathrm{pH}$ is a $\mu$-oxido diFe(III) species with a bent oxido bridge. The shoulder at $381 \mathrm{~nm}$ could in principle also originate from the phenolate-to-Fe(III) CT transition but the very weak shoulder at about $460 \mathrm{~nm}$ (1a, Figure 9a), more clearly detected in the derivative spectrum in the inset of Figure 9a, is more likely from this CT transition. The spectrum of $\mathbf{2}$ at $\mathrm{pH} 10$ is compared to that of $7(\mathrm{FeCu})$ in acetonitrile in Figure 9b. For 7 the single shoulder at $336 \mathrm{~nm}(3 \mathrm{~b})\left(10000 \mathrm{M}^{-1} \mathrm{~cm}^{-1}\right)$ fits well with a linearly bridged $\mu$-oxido-diFe(III) center as observed in the crystal structure (Figure 6). For 2 a shoulder at the same wavelength (336 nm, (3a)) is observed indicating that the structure of 2 at high $\mathrm{pH}$ might be similar to that of 7 although for the latter complex the bridge in the solid state is perfectly linear. In a separate study, we have prepared the oxido- and pivalate-bridged $\mathrm{diFe}(\mathrm{III})$ complex $\left[\{\mathrm{Fe}(\mathrm{IPCPMP})\}_{2}(\mu-\mathrm{O})\right.$ ( $\mu$-1,3-pivalate) $] \mathrm{ClO}_{4}{ }^{77}$ Its $\mathrm{UV}$-vis spectra is not very similar to that detected for $\mathbf{2}$ at high $\mathrm{pH}$, and it is therefore not likely that the high $\mathrm{pH}$ form of $\mathbf{2}$ is such a diiron species. From the fit of a sigmoidal Boltzmann function to the change of a specific absorption versus $\mathrm{pH}$ (Supporting Information, Figure S1), the $\mathrm{pH}$ at 50\% conversion can be extracted, and this corresponds to the $\mathrm{p} K_{\mathrm{a}}$ of the functional group that undergoes the assumed protolysis. For complex 2, two different $\mathrm{p} K_{\mathrm{a}}{ }^{\prime}$ s can be estimated, 6.8 for the disappearing peak at $518 \mathrm{~nm}$, and 8.3 for the two peaks forming at 336 and $383 \mathrm{~nm}$. However, for a direct transformation of one species to another, and hence isosbestic points in general, the estimated $\mathrm{pH}$ at $50 \%$ conversion should be the same for the peaks that disappear in the starting materials and the peaks that appear in the product at high $\mathrm{pH}$. For $\mathbf{2}(\mathrm{FeZn})$ this is clearly not the case. If, for two consecutive deprotonations, an intermediate that has an absorption maximum coinciding with the spectral traces of the starting and final species exists, then isosbestic points may still be observed. This behavior is partially observed for complex $4(\mathrm{FeNi})$ and $\mathbf{5}(\mathrm{FeMn})$ (vide infra).

The spectra of complex 3 (FeCo, Figure $8 \mathrm{~b}$ ) show similar $\mathrm{pH}$ dependence as $\mathbf{2}$. At high $\mathrm{pH}$, two weak shoulders are visible in the same region as the oxido-to-Fe(III) CT bands for 2, but 3 is not completely converted even at $\mathrm{pH} 10.5$. The band at $510 \mathrm{~nm}$, observed at low $\mathrm{pH}$, has however disappeared at $\mathrm{pH} 9$, and a sigmoidal fit to its change with increasing $\mathrm{pH}$ gives a $\mathrm{p} K_{\mathrm{a}}$ of 7.1.

Complex $4(\mathrm{FeNi})$ and $\mathbf{5}(\mathrm{FeMn})$ behave similarly to each other (Figure $8 \mathrm{c}$ and $\mathrm{d}$ ) with a shift of the phenolate to $\mathrm{Fe}$ (III) CT bands from 517 and $505 \mathrm{~nm}$ to 446 and $440 \mathrm{~nm}$, respectively, when going from $\mathrm{pH} 5$ to 10 , with a slight decrease in intensities but without the formation of oxido to $\mathrm{Fe}$ (III) dimer CT bands that were observed for $\mathbf{2}$ and 3 . The $\mathrm{p} K_{\mathrm{a}}$ 's for these processes, derived from sigmoidal fits to the $\mathrm{pH}$ dependence of the absorbances at 517 and $505 \mathrm{~nm}$, are different, however (6.9 and 8.2 , respectively). The maximum absorbance for the band forming at high $\mathrm{pH}$, for both $\mathbf{4}$ and $\mathbf{5}$, is close to the isosbestic point, and hence the absorbance changes very little at this wavelength and no sigmoidal fit to its $\mathrm{pH}$ dependence is possible. This may be related to the presence of an isosbestic point for complex 2 (FeZn), if a similar complex with a similar absorbance is formed as an intermediate between two consecutive deprotonation reactions as proposed above for 2 . The nature of the species that is formed at high $\mathrm{pH}$ for complexes 4 and $\mathbf{5}$, and possibly as an intermediate in the case of 2 , is at the moment not known. Its formation may involve deprotonation of a bridging or terminal water molecule, and the fact that the observed $\mathrm{p} K_{\mathrm{a}}$ for the process is different for $\mathbf{4}$ and $\mathbf{5}$ suggests that this water interacts with the divalent metal.

In summary, on the basis of the above-mentioned spectroscopic observations, we tentatively propose that complex 2 $(\mathrm{FeZn})$ is converted into a dimer of heterodinuclear dimers, linked via an $\mathrm{Fe}-\mathrm{O}-\mathrm{Fe}$ bond, at $\mathrm{pH}>$ 9. A similar dimer of dimers may be formed at high $\mathrm{pH}$ in the case of complex 3 ( $\mathrm{FeCo}$ ) but appears not to form for complexes $4(\mathrm{FeNi})$ and $\mathbf{5}$ (FeMn). The lack of clear spectroscopic signatures for the two latter complexes prevents us from assigning any definite structure for the species formed at high $\mathrm{pH}$ in their cases. 

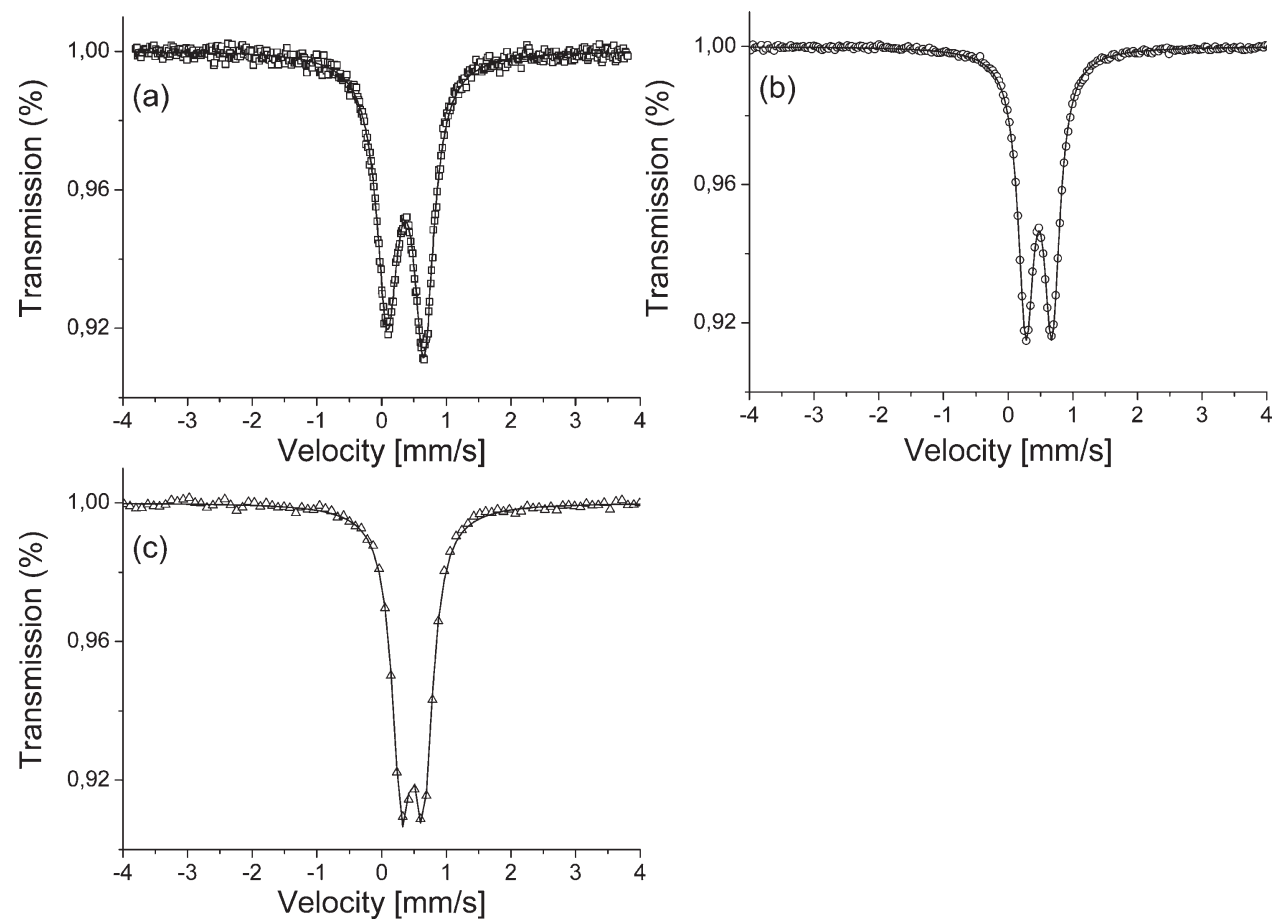

Figure 10. Mössbauer spectra at $80 \mathrm{~K}$ of $\left.\left[\mathrm{Fe}(\mathrm{III})\left(\mathrm{H}_{2} \mathrm{IPCPMP}\right)\left(\mathrm{Cl}_{2}\right)\right]\left[\mathrm{PF}_{6}\right]\right)(\mathbf{1})(\mathrm{a}),\left[\mathrm{Fe}(\mathrm{III}) \mathrm{Co}(\mathrm{II})(\mathrm{IPCPMP})(\mathrm{OAc})_{2}\left(\mathrm{CH}_{3} \mathrm{OH}\right)\right][\mathrm{PF} 6](\mathbf{3})(\mathrm{b})$, and $\left[\mathrm{Fe}(\mathrm{III}) \mathrm{Mn}(\mathrm{II})(\mathrm{IPCPMP})(\mathrm{OAc})_{2}\left(\mathrm{CH}_{3} \mathrm{OH}\right)\right]\left[\mathrm{PF}_{6}\right](5)(\mathrm{c})$ in the solid state.

Table 3. Magnetic Data for $\left[\mathrm{Fe}(\mathrm{III}) \mathrm{M}(\mathrm{II})(\mathrm{IPCPMP})(\mathrm{OAc})_{2}\left(\mathrm{CH}_{3} \mathrm{OH}\right)\right]\left[\mathrm{PF}_{6}\right](\mathrm{M}=\mathrm{Zn}(2), \mathrm{Co}(3), \mathrm{Ni}(4)$, and $\mathrm{Mn}(5))$ and Mössbauer Parameters for Complexes $1-5$ at $80 \mathrm{~K}$

\begin{tabular}{|c|c|c|c|c|c|c|c|}
\hline \multirow[b]{2}{*}{ complex } & \multicolumn{5}{|c|}{ susceptibility data } & \multicolumn{2}{|c|}{ Mössbauer data } \\
\hline & $J_{12}\left[\mathrm{~cm}^{-1}\right]$ & $g_{\mathrm{Fe}(\mathrm{III})}$ & $g_{\mathrm{M}(\mathrm{II})}$ & $P I[\%](S=5 / 2)$ & $\operatorname{TIP}\left[10^{-6} \mathrm{~cm}^{3} / \mathrm{mol}\right]$ & isomeric shift $\delta(\mathrm{mm} / \mathrm{s})$ & quad. split $\Delta E_{\mathrm{Q}}(\mathrm{mm} / \mathrm{s})$ \\
\hline 1 & & & & & & 0.48 & 0.56 \\
\hline 2 & & 1.94 & & 0.0 & 558 & 0.53 & \\
\hline 3 & -5.4 & 2.09 & 1.92 & 0.4 & 111 & 0.47 & 0.40 \\
\hline 4 & -11.2 & 1.96 & 2.19 & 0.1 & 152 & 0.50 & \\
\hline 5 & -9.6 & 1.99 & 1.99 & 0.3 & 114 & 0.47 & 0.33 \\
\hline
\end{tabular}

Mössbauer Spectroscopy. To probe the electronic environment of the $\mathrm{Fe}$ in various heterodinuclear complexes, and to verify the oxidation and spin states of iron, the Mössbauer spectra of 1 (Fe-mono), 2 (FeZn), 3 (FeCo), 4 (FeNi), and 5 (FeMn) were recorded. The spectra of $\mathbf{1}, \mathbf{3}$, and $\mathbf{5}$ (Figure $10 \mathrm{a}, \mathrm{b}$ and $\mathrm{c}$, respectively) show isomer shifts and quadrupole splittings typical of a high spin $\mathrm{Fe}$ (III) ion (Table 3). The isomer shifts are very similar, and the smaller quadrupole splittings for $\mathbf{4}$ and $\mathbf{5}$ as compared to $\mathbf{1}$ are likely due to the more symmetrical environment with only nitrogen and oxygen donors at similar distances around the $\mathrm{Fe}$ (III) for the former two. The $\mathrm{Fe}(\mathrm{III})-\mathrm{Cl}$ bonds are significantly $(\sim 0.1 \AA)$ longer than the other bonds to the metal in $\mathbf{1}$, yielding a less symmetrical environment. The broad appearance and absence of quadrupole splitting for the resonances in the spectra of $\mathbf{2}$ and $\mathbf{4}$ (Figure 11a and b, respectively) indicate relaxation effects because the electronic spin relaxation is on the same time scale as the Larmor frequency of the nuclei. ${ }^{78}$ Spin-lattice relaxation involves a transfer of Zeeman energy of the spin system to phonon modes of the lattice via spin-orbit coupling and is temperature dependent. By this effect the spectra get broader at lower temperature, and this is indeed observed for 2 when comparing spectra at 80 and $7 \mathrm{~K}$ (Supporting Information, Figure S2 a and b, respectively) and for $\mathbf{4}$ when comparing the spectra at 295 and $80 \mathrm{~K}$ (Supporting Information, Figure S3 a and $b$, respectively). The presence of relaxation effects for 2 $(\mathrm{FeZn})$ and $\mathbf{4}(\mathrm{FeNi})$ but not for $\mathbf{3}$ (FeCo) is difficult to explain since the structures and crystallographic symmetry for all three are very similar, assuming that crystallographic homogeneity prevails in the bulk solid.

Magnetic Properties. Magnetic susceptibility measurements were carried out for complexes 2 (FeZn), 3 (FeCo), 4 (FeNi), and $\mathbf{5}(\mathrm{FeMn})$ at magnetic fields of $5000 \mathrm{Oe}$ in the temperature range $295-2 \mathrm{~K}$. The temperature dependence of the effective magnetic moments $\left(\mu_{\text {eff }} / \mu_{\mathrm{B}}\right)$ are shown in Figure $12 \mathrm{a}-\mathrm{d}$. The experimental data for the complexes were modeled by using a fitting procedure to the appropriate Heisenberg-Dirac-van Vleck (HDvV) spin Hamiltonian for isotropic exchange coupling and Zeeman splitting, eq $1 .^{79}$

$$
\hat{H}=-2 J \hat{S}_{1} \cdot \hat{S}_{2}+g \mu_{\mathrm{B}}\left(\hat{S}_{1}+\hat{S}_{2}\right) B
$$



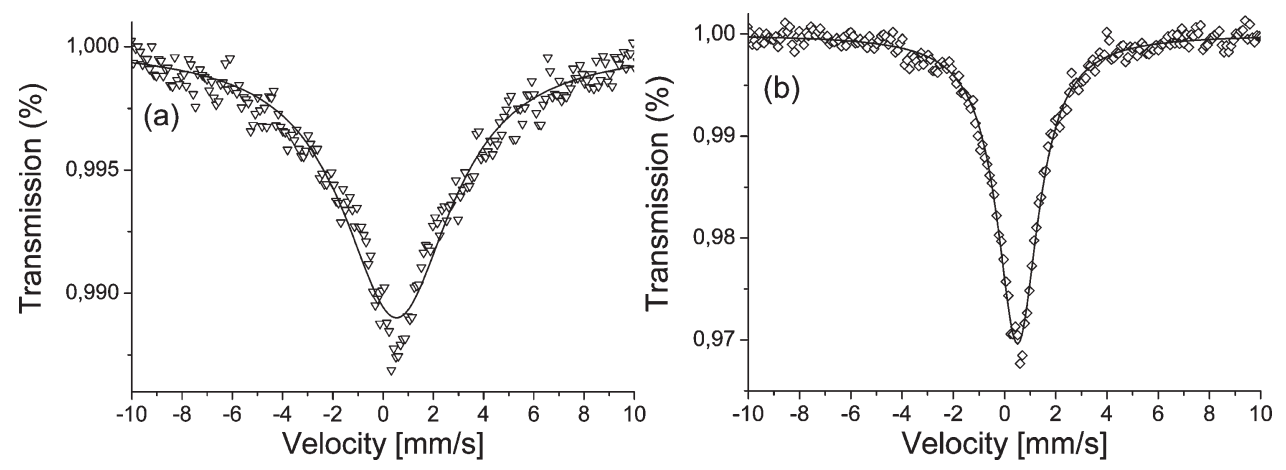

Figure 11. Mössbauer spectra at $80 \mathrm{~K}$ of $\left[\mathrm{Fe}(\mathrm{III}) \mathrm{Zn}(\mathrm{II})(\mathrm{IPCPMP})(\mathrm{OAc})_{2}\left(\mathrm{CH}_{3} \mathrm{OH}\right)\right]\left[\mathrm{PF}_{6}\right]$ (2) (a) and $\left[\mathrm{Fe}(\mathrm{III}) \mathrm{Ni}(\mathrm{II})(\mathrm{IPCPMP})(\mathrm{OAc})_{2}\right.$ $\left.\left(\mathrm{CH}_{3} \mathrm{OH}\right)\right]\left[\mathrm{PF}_{6}\right](4)(\mathrm{b})$ in the solid state.
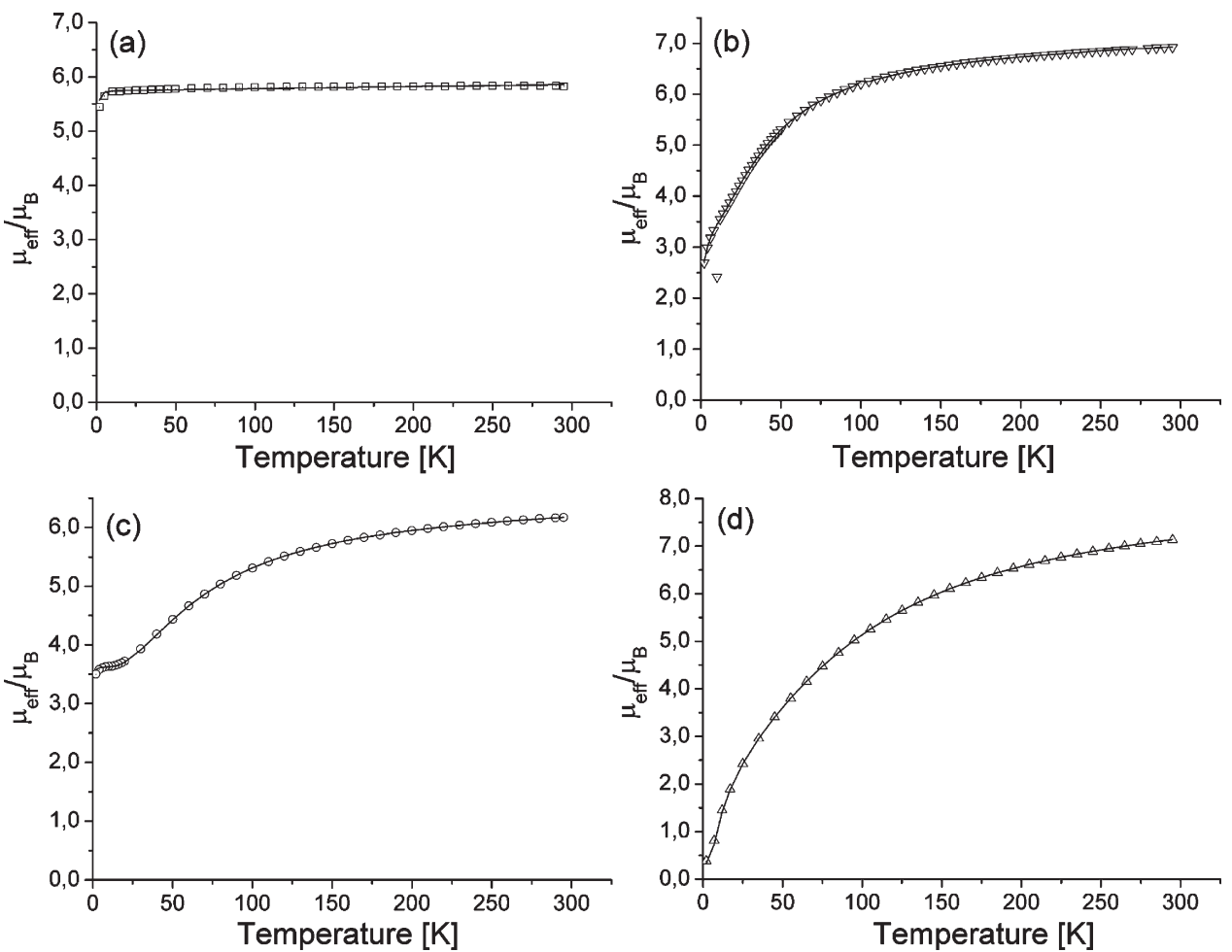

Figure 12. Effective magnetic moment versus temperature for [ $\left.\mathrm{Fe}(\mathrm{III}) \mathrm{M}(\mathrm{II})(\mathrm{IPCPMP})(\mathrm{OAc})_{2}\left(\mathrm{CH}_{3} \mathrm{OH}\right)\right][\mathrm{PF} 6](\mathrm{M}=\mathrm{Zn} 2$ (a), Co 3 (b), Ni 4 (c), and $\operatorname{Mn} 5(\mathrm{~d}))$. The solid lines are least-squares fits to the theoretical expression.

Temperature-independent paramagnetism $(T I P)$ and a paramagnetic impurity $(P I)$ with spin $S=5 / 2$ and Curie behavior were included according to $\chi_{\text {calc }}=(1-P I) \cdot \chi+P I \cdot \chi_{\text {mono }}+$ TIP. ${ }^{80}$ The parameters from the fitting are presented in Table 3. The data for $2(\mathrm{FeZn})$ (Figure 12a) indicate a magnetically isolated high spin $\mathrm{Fe}(\mathrm{III})$ center, as expected, with a magnetic moment of $5.83 \mu_{\mathrm{B}}$ at room temperature and a calculated $g$ value of 1.94. The data for 3 (FeCo), 4 ( FeNi), and 7 (FeMn) (Figure $12 b-c$ ) all display local magnetic ordering when the temperature is decreased, indicating magnetic exchange coupling between the two metal centers in the complexes, and the analysis reveals weak antiferromagnetic coupling for all three. For 3, the data correlate well with the formulation of the complex as containing high spin $\mathrm{Fe}$ (III) and $\mathrm{Co}$ (II) ions with an exchange coupling $J_{12}=-5.4 \mathrm{~cm}^{-1}$, comparable to previously reported
FeCo complexes of a similar phenolate ligand with $J_{12}=-6$ and $-10 \mathrm{~cm}^{-1}$. ${ }^{64}$ The possibility of a Co(III)Fe(II) complex can be ruled out since for high spin $\mathrm{Co}$ (III) $(S=2)$ and high spin $\mathrm{Fe}$ (II) $(S=2)$ antiferromagnetic coupling would yield an $S=0$ ground state. The remaining magnetic moment of $2.71 \mu_{\mathrm{B}}$ observed at low temperature is in conflict with this unless about $30 \%$ paramagnetic impurities are assumed. A low spin $\mathrm{Co}(\mathrm{III})$ would not contribute to any magnetism and hence a simple $\mathrm{Fe}$ (II) paramagnetic behavior would be observed. The Mössbauer spectra also clearly indicate a high spin $\mathrm{Fe}$ (III) in the complex (vide supra). In the case of $\mathbf{5}$, the same dilemma can not be resolved by magnetic susceptibility measurements, but the Mössbauer spectra clearly indicate a high spin Fe(III) center supporting the formulation of $\mathbf{5}$ as high spin $\mathrm{Fe}$ (III) and $\mathrm{Mn}$ (II), that from the fitting yields an antiferromagnetic exchange 
Scheme 1

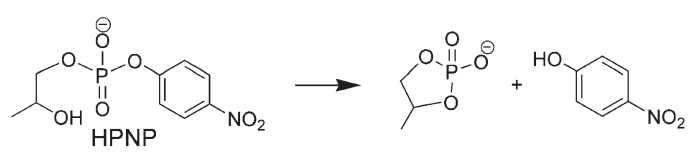

(NDNPP

interaction of $J_{12}=-9.6 \mathrm{~cm}^{-1}$. This correlates well with previously determined values for FeMn complexes of the phenolate-based ligands BPMP $\left(-11.5 \mathrm{~cm}^{-1}\right),{ }^{69} \mathrm{BIMP}^{81}$ $\left(-7.7 \mathrm{~cm}^{-1}\right)$, and BPBPMP ${ }^{59}\left(-6.8 \mathrm{~cm}^{-1}\right)$ (Schematic drawings are shown in Figure 2). In the case of $\mathbf{4}$ the data could successfully be fitted to a high spin $\mathrm{Fe}$ (III) and high spin $\mathrm{Ni}$ (II) with an exchange coupling of $-11.2 \mathrm{~cm}^{-1}$ in line with other $\mathrm{Fe}(\mathrm{III}) \mathrm{Ni}$ (II) complexes of the BPBPMP ligand, both with and without exogenous carboxylate bridges (in the range -13.2 to $\left.-13.7 \mathrm{~cm}^{-1}\right), 82$ and the BPMP ligand $\left(-11.5 \mathrm{~cm}^{-1}\right)^{55}$ with two propionate bridges, suggesting that the principal superexchange pathway is transmitted over the phenolate bridge in all cases. On the other hand, $\mathrm{Fe}(\mathrm{III})-\mathrm{Co}(\mathrm{II})$ and $\mathrm{Fe}(\mathrm{III})-\mathrm{Ni}(\mathrm{II})$ complexes of a bis- $\mu$-phenolato macrocyclic ligand (Figure $2 \mathrm{c}$ ) studied by Dutta et al. ${ }^{66}$ have a weak ferromagnetic interaction $\left(J_{12}=4.2\right.$ and $\left.1.7 \mathrm{~cm}^{-1}\right)$. The observed ferromagnetic coupling was rationalized by a more acute $\mathrm{Fe}(\mathrm{III})-\mathrm{O}-\mathrm{M}$ (II) angle $\left(92.8^{\circ}\right)$. The results here are in line with this description since the $\mathrm{Fe}(\mathrm{III})-\mathrm{O}$ (phenolato) $-\mathrm{M}$ (II) angles are all significantly larger $\left(>110^{\circ}\right)$ than $90^{\circ}$, as for the previously mentioned FeNi complexes of BPBPMP $^{82}$ and BPMP. 55

Transesterification of 2-Hydroxypropyl-para-nitrophenol Phosphate (HPNP). To test if complexes 2 (FeZn), 3 (FeCo), 4 (FeNi), and $\mathbf{5}$ (FeMn) also are functional models, their activities toward cleavage of two phosphoester substrates, 2-hydroxypropyl-para-nitrophenyl phosphate (HPNP) and bis(2,4-dinitrophenyl)phosphate (BDNPP), were tested (Scheme 1).

First the $\mathrm{pH}$ dependence of their reactivities was investigated, and, as seen in the graphs in Figure 13, all complexes enhance HPNP transesterification although there are considerable differences in their reactivities. Highest activity is shown by complex 3 (FeCo), with a rate 200 times that of the noncatalyzed reaction $\left(v_{\mathrm{i}, \text { cat }} / v_{\mathrm{i} \text {, uncat }}\right)$ at $\mathrm{pH} 7$ and 475 times at $\mathrm{pH}$ 8. Complex $4(\mathrm{FeNi})$ also shows activity at $\mathrm{pH}>6$ (a factor of 75 at $\mathrm{pH} 7$ and 120 at $\mathrm{pH}$ 8 compared to the noncatalyzed reaction). A sigmoidal shape for the rate versus $\mathrm{pH}$ (Figure 13a) is observed for 4 until approximately $\mathrm{pH} 9.5$ where the noncatalyzed reaction becomes important. A sigmoidal Boltzmann function fitted for $\mathrm{pH}$ 6-9.5 gives a $\mathrm{pH}$ of 8.3 at $\mathrm{v}_{0 \max } / 2$, which might correspond to a pre-equilibrium deprotonation of the substrate, if the alcohol group is coordinated to one of the metals, or a coordinated water molecule. Complex 5 also shows a sigmoidal $\mathrm{pH}$ dependence with a rate enhancement at $\mathrm{pH} 7$ and 8 by factors of 14 and 94, respectively, compared to the noncatalyzed reaction. The downward bend of the curve at $\mathrm{pH} 10$ and above is probably due to decomposition of the complex, and at $\mathrm{pH}>9$ precipitation of what presumably is a metal hydroxide species is observed for complex $\mathbf{5}$.

Surprisingly, complex 2 (FeZn), which according to metal content should be a good model for kidney bean purple acid phosphatase, shows a different $\mathrm{pH}$ dependence and much lower
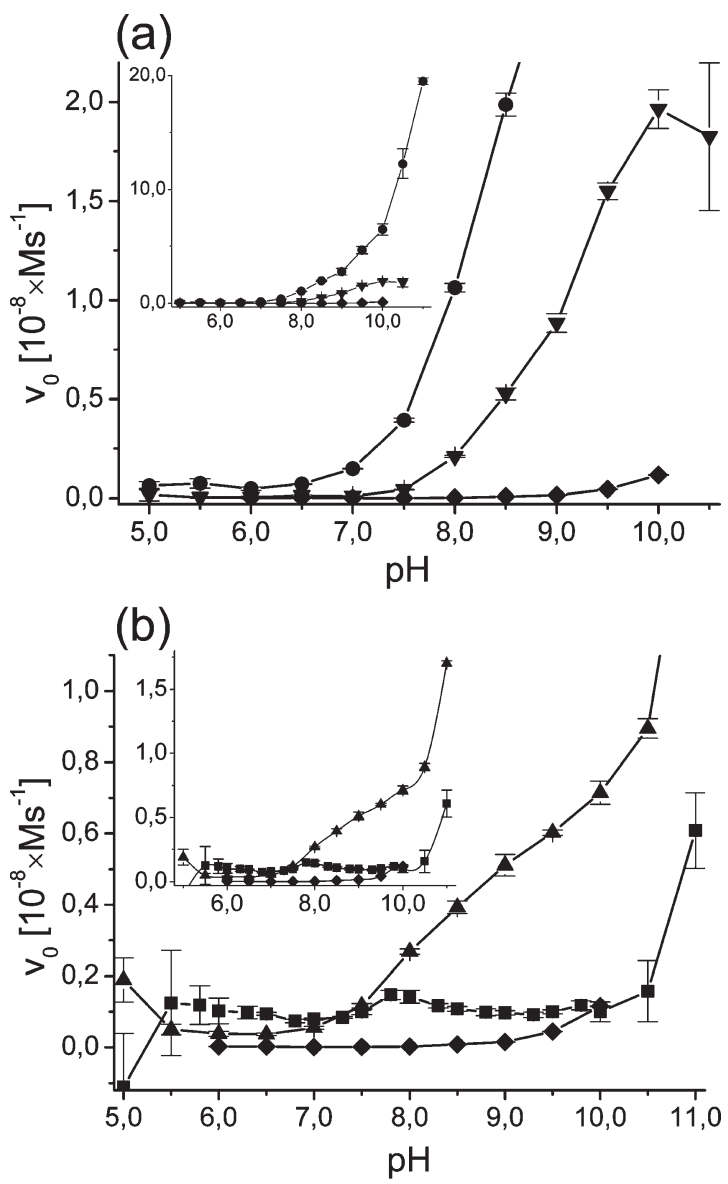

(c)

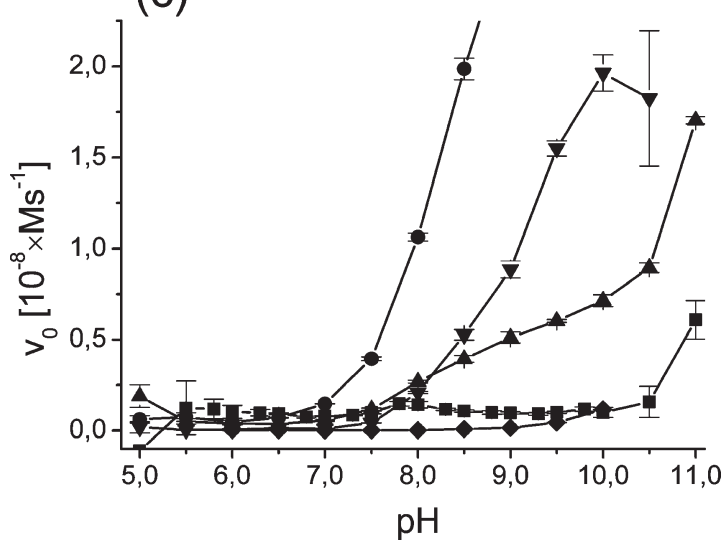

Figure 13. Dependence on $\mathrm{pH}$ of HPNP transesterification enhanced by $\left[\mathrm{Fe}(\mathrm{III}) \mathrm{M}(\mathrm{II})(\mathrm{IPCPMP})(\mathrm{OAc})_{2}\left(\mathrm{CH}_{3} \mathrm{OH}\right)\right]\left[\mathrm{PF}_{6}\right](\mathrm{M}=\mathrm{Zn}$ (2) $(\square), \mathrm{Co}(3)(\bullet), \mathrm{Ni}(4)(\mathbf{\Delta})$ and $\mathrm{Mn}(\mathbf{5})(\boldsymbol{\nabla})$. For clarity 2 and 4 are displayed in (a) and $\mathbf{3}$ and $\mathbf{5}$ in (b) along with the noncatalyzed reaction $(\downarrow)$. For comparison all traces are shown in (c). Lines displayed are only to guide the eye and are not fitted curves. The data for $\mathbf{2}$ have been corrected for changes in the background absorbance (see Experimental Section).

activity at high $\mathrm{pH}$. An absolute maximum occurs at $\mathrm{pH} 8$, but the maximum rate enhancement with a factor of 143 relative to the uncatalyzed reaction occurs at $\mathrm{pH}$ 7. The decline in activity after $\mathrm{pH} 8$ may be related to the formation of the $\mu$-oxido-bridged species which 2 (FeZn), based on UV-vis spectroscopy, is proposed to convert to at high $\mathrm{pH}$. 

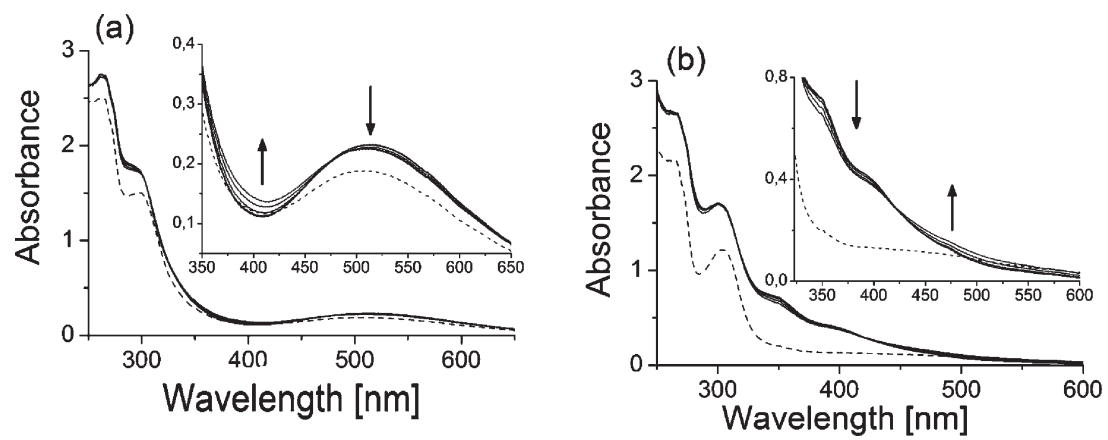

Figure 14. Scanning kinetics for the decomposition of $\left[\mathrm{Fe}(\mathrm{III}) \mathrm{Zn}(\mathrm{II})(\mathrm{IPCPMP})(\mathrm{OAc})_{2}\left(\mathrm{CH}_{3} \mathrm{OH}\right)\right]\left[\mathrm{PF}_{6}\right](2)$ in buffered water-acetonitrile solution at $\mathrm{pH} 6(\mathrm{a})$ and 10 (b). The arrows show the direction of change over time. The dotted lines represent the spectrum after $24 \mathrm{~h}$.

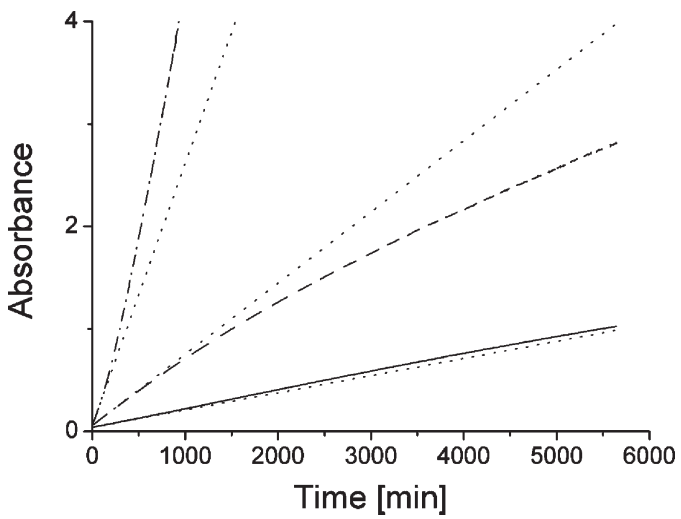

Figure 15. Kinetic traces of HPNP transesterification enhanced by $\left[\mathrm{Fe}(\mathrm{III}) \mathrm{M}(\mathrm{II})(\mathrm{IPCPMP})(\mathrm{OAc})_{2}\left(\mathrm{CH}_{3} \mathrm{OH}\right)\right]\left[\mathrm{PF}_{6}\right](\mathrm{M}=\mathrm{Zn}(2)$ at $\mathrm{pH}$ $8.0(-), \mathrm{Co}(3)$ at $\mathrm{pH} 9.0(-.-)$, and $\mathrm{Ni}(4)$ at $\mathrm{pH} 9.0(--)$. The dotted lines are linear fits to the initial parts $(20-80 \mathrm{~min})$ of the curves. Complex and substrate concentrations are $0.025 \mathrm{mM}$ and $0.80 \mathrm{mM}$, respectively.

The kinetic traces show that for all complexes there is a short lag time of approximately 3-5 min (Supporting Information, Figure S4). This suggests that the complexes undergo a rearrangement to become active in the HPNP transesterification (or the BDNPP hydrolysis, vide infra), possibly involving substitution of coordinated groups by the substrate. Complexes $\mathbf{3}$ and $\mathbf{4}$ exhibit well-behaved kinetics (Supporting Information, Figure S4). Complex 5 also appears to behave well at low $\mathrm{pH}$, but at higher $\mathrm{pH}$ loss of activity and complicated absorbance versus time dependence indicate degradation of the complex. This decomposition becomes significant already at $\mathrm{pH} 8.5$ (after about 300 min) and severely distorts the traces at $\mathrm{pH}>9.5$, in agreement with the observed precipitation at high $\mathrm{pH}$ (vide supra).

For $2(\mathrm{FeZn})$ and $3(\mathrm{FeCo})$ the rate increases over time at $\mathrm{pH}>$ 8 and 9, respectively. This suggests that the complexes are slowly transformed into more active species. The change over time in the UV/vis spectra of 2 at $\mathrm{pH} 6$ and 10 without added substrate is displayed in Figure 14a and b, respectively. The complex appears to be fairly stable at $\mathrm{pH} 6$ with only a slight decrease in absorbance after $24 \mathrm{~h}$. At $\mathrm{pH} 10$ and during $380 \mathrm{~min}$ $(\sim 6 \mathrm{~h})$ there is a small decrease in intensity of the shoulders around 340 and $390 \mathrm{~nm}$, but the spectra after $24 \mathrm{~h}$ indicate significant decomposition and a small amount of precipitate could indeed be observed. The latter spectra lack the characteristic oxido or phenolate to $\mathrm{Fe}$ (III) CT bands characteristic of the
Fe-containing complexes in this study. Previous studies of dinuclear $\mathrm{Zn}$ complexes of the same and similar ligands show that they are more active than $\mathbf{2}$ toward HPNP transesterification at $\mathrm{pH}>7,{ }^{47,83}$ indicating that formation of homodinuclear $\mathrm{Zn}$ complexes from 2 at $\mathrm{pH}>8$ might be responsible for the increase in rate with time. This is likely the case also for complex 3 at $\mathrm{pH}>$ 9 as both these complexes, according to FAB-MS data (vide supra) generate diZn and diCo complexes upon prolonged standing in basic solutions. The formation of the homodinuclear complex(es) appears to be slow (half-life of $2>12 \mathrm{~h}$ ); thus the observed activity based on initial rates may safely be attributed to the heterodinuclear species.

All complexes appear to be able to support multiple turnovers, as calculated from the extinction coefficient of the produced 4nitrophenol $\left(18500 \mathrm{M}^{-1} \mathrm{~cm}^{-1}\right)$ and the measured absorbance after $5500 \mathrm{~min}$ for complex and substrate concentrations of $0.025 \mathrm{mM}$ and $0.8 \mathrm{mM}$, respectively. The analysis is, however, hampered by the slow reactions and decomposition at prolonged times. Figure 15 shows kinetic traces for HPNP transesterification by $2(\mathrm{FeZn}), 3(\mathrm{FeCo})$, and 4 (FeNi) at $\mathrm{pH}$ 8.0, 9.0, and 9.0, respectively. In all cases, the plots indicate multiple turnovers although for complex 2 only two turnovers were measured during the time of the experiment (over 4 days). Complex 3, which is the most active one toward HPNP transesterification, displays 13 turnovers within the first $1000 \mathrm{~min}$ (after which the detector was saturated). Complex 4 produces six turnovers over 4 days without any discernible decomposition or other unexpected change in the kinetic trace.

Hydrolysis of Bis-dinitrophenol Phosphate (BDNPP). The hydrolysis of BDNPP was studied under identical conditions as the HPNP transesterification, and the $\mathrm{pH}$ dependence of the initial rates was investigated (Figure 16). As for the reaction with HPNP, great diversity in reactivity is observed. Complexes 2 (FeZn) and 3 (FeCo) exhibit bell-shaped behavior for $\mathrm{pH} 5-7.5$, with an initial rate maximum at about $\mathrm{pH}$ 6.5. This type of behavior is also observed for other similar heterodinuclear complexes ${ }^{56-60}$ as well as for the PAPs. ${ }^{84}$ Complex $\mathbf{5}$ (FeMn) also reaches a saturation point at $\mathrm{pH} 6.5$, but no decline is observed at higher $\mathrm{pH}$. Interestingly, the initial rate of BDNPP hydrolysis enhanced by complex $4(\mathrm{FeNi})$ shows zeroth order dependence on $\mathrm{pH}$ between $\mathrm{pH} 5$ and 6.5. This behavior is strikingly different from that of the previously reported heterodinuclear complexes which all show bell-shaped $\mathrm{pH}$ dependence. ${ }^{56-60}$ It may be noted that the order of reactivity of our complexes at acidic $\mathrm{pH}$ is similar to that observed for substituted forms of uteroferrin. Sykes and coworkers $^{85}$ have observed that at $\mathrm{pH} 4.9$, the general reactivity 


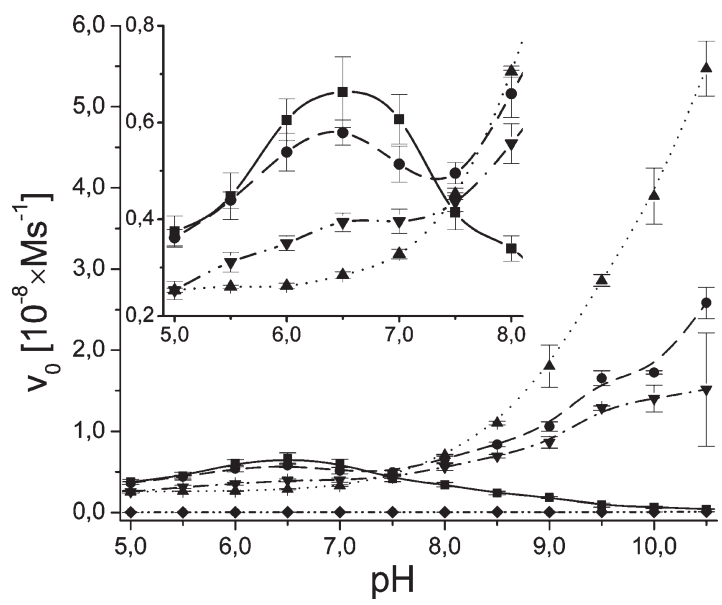

Figure 16. Dependence on $\mathrm{pH}$ of the initial rates for the hydrolysis of BDNPP enhanced by $\left[\mathrm{Fe}(\mathrm{III}) \mathrm{M}(\mathrm{II})(\mathrm{IPCPMP})(\mathrm{OAc})_{2}\left(\mathrm{CH}_{3} \mathrm{OH}\right)\right]-$ $\left[\mathrm{PF}_{6}\right](\mathrm{M}=\mathrm{Zn}(\mathbf{2})(\mathbf{\square}), \mathrm{Co}(3)(\mathbf{\bullet}), \mathrm{Ni}(4)(\mathbf{\Delta})$, and $\mathrm{Mn}(\mathbf{5})(\boldsymbol{\nabla})$. The curves are not fitted lines but only a guide for the eye.

order is $\mathrm{FeZn}>\mathrm{FeMn}>\mathrm{FeCo}>\mathrm{FeNi}$ (for reaction with $\mathrm{H}_{2} \mathrm{PO}_{4}{ }^{-}$), while we observe the following order for our complexes: FeZn $>$ FeCo $>$ FeMn $>$ FeNi $(\mathrm{pH} 6.5)$.

At $\mathrm{pH}>7.5$ the rate for $\mathbf{2}$ continues to decrease after the rate maximum, while for complex 3, 4, and 5 the rates increase with increasing $\mathrm{pH}$. For 2, a sigmoidal fit to the declining part of the rate profile yields a $\mathrm{pH}$ of 7.9 for $\mathrm{v}_{0 \max } / 2$, which may correspond to the $\mathrm{p} K_{\mathrm{a}}$ value of a coordinated water or hydroxide. This assumed $\mathrm{p} K_{\mathrm{a}}$ corresponds reasonably well to that derived from the $\mathrm{pH}$ dependence of the oxido to $\mathrm{Fe}$ (III) charge transfer band for $2\left(\mathrm{p} K_{\mathrm{a}} 8.3\right.$, vide supra and Supporting Information, Figure $\mathrm{S} 1)$, suggesting that the presumed oxido-bridged species thus formed is inactive in the hydrolysis of BDNPP (and HPNP). As noted previously, complex 3 also seems to form a species reminiscent of the oxido-species formed for 2 . The conversion is, however, incomplete even at $\mathrm{pH} 10.5$ which might explain why 3 shows activity at higher $\mathrm{pH}$.

Downward bends as for $\mathbf{2}$ (FeZn), 3 (FeCo), and $\mathbf{5}$ (FeMn) around $\mathrm{pH} 6.5$ (Figure 16, inset) indicate that there is a sequence of steps in the mechanism suggesting that some $\mathrm{pH}$-dependent rearrangement of the complex (or the substrate) prior to phosphoester cleavage is necessary for the reaction to occur. This might involve deprotonation of a metal-bound water molecule, a process that is frequently associated with the activation of the attacking nucleophile. In this respect it is interesting to note that 2, 3, and 5 have initial rate maxima at about the same $\mathrm{pH}$ (6.5), while some variation in $\mathrm{pH}$ for the maxima may be expected if the nucleophile were bound to the divalent metal. Complex $\mathbf{5}$ has considerably lower activity which possibly can be explained by the lower Lewis acidity of the $\mathrm{Mn}$ (II) ion. It should, however, be noted that the ESI-MS+ spectrum of $\mathbf{5}$ in water/ acetonitrile indicated dissociation of the complex into a mononuclear Fe(III) complex. The lower activity might, hence, be due to decomposition of the complex. From the observations it can be proposed that the active nucleophile is an hydroxide terminally coordinated to the $\mathrm{Fe}$ (III) ion.

The bell-shaped $\mathrm{pH}$ dependence for $\mathbf{2}$ and $\mathbf{4}$ as well as other heterodinuclear complexes and the PAP enzymes is the result of a second deprotonation event that inhibits the reaction at higher $\mathrm{pH}$. For the enzymes this has been related to deprotonation of
Scheme 2

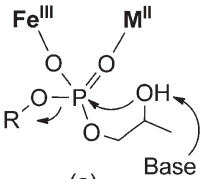

(a)

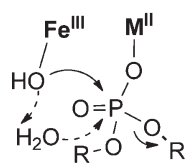

(d)

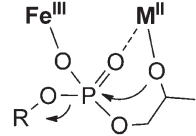

(b)

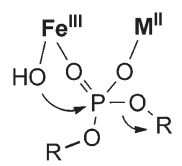

(e)

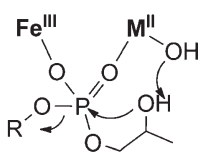

(c)

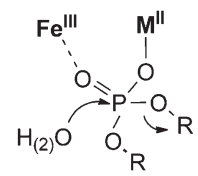

(f) the product (dihydrogen phosphate) or some amino acid residue in the active site important for reactivity, ${ }^{12,19}$ while for other heterodinuclear complexes the substrate is proposed to be inhibited to bind to the complex because of competition with coordinated hydroxides forming at the divalent metal at high pH. ${ }^{56-60}$ For 2 and 3 the decrease seems to be correlated with the formation of the proposed $\mu$-oxido diFe(III) species. Attempts to fit the data to an equation for a diprotic model yielded large errors for the dissociation constants that are probably due to competing $\mathrm{pH}$ dependent processes. The zeroth order dependence of complex $\mathbf{4}$ is surprising and indicates that water, presumably noncoordinated, is the active nucleophile. As mentioned in the introduction, it has been proposed that the active nucleophile for uteroferrin and its $\mathrm{Fe}$ (III) Mn(II) derivative is a water (hydroxide) in the secondary coordination sphere of the metal core (vide supra and Scheme 2d). The ESI-MS of 4 in aqueous solution indicates the presence of hydroxide complexes of similar stoichiometry as for 2 and 3; the reason for the difference in $\mathrm{pH}$ dependence of these complexes for BDNPP hydrolysis is currently not known.

For complexes 3 (FeCo), $4(\mathrm{FeNi})$, and $\mathbf{5}(\mathrm{FeMn})$ there is an increase in activity with increasing $\mathrm{pH}$ once the $\mathrm{pH}$ rises above $\mathrm{pH} 7-7.5$; this is in contrast to what has been observed for similar heterodinuclear complexes that hydrolyze BDNPP. ${ }^{56-60}$ This increase in the hydrolytic activity suggests that two parallel pathways are active and either one dominates over the other at different $\mathrm{pHs}$. The fact that no maximum rate appears to be approached at very high $\mathrm{pH}$ would suggest that there is no preequilibrium deprotonation to form a coordinated and nucleophilic hydroxide, suggesting that it either is a noncoordinated hydroxide making the nucleophilic attack on the metal coordinated substrate, or that there is a concerted deprotonation of a coordinated water molecule during the attack. At low $\mathrm{pH}$, where there is no dependence on $\mathrm{OH}^{-}$(or $\mathrm{H}^{+}$) for 4 (vide supra), the nucleophile is probably noncoordinated water. In comparison to similar heterodinuclear complexes used in previous studies, ${ }^{56-60}$ the divalent metal has one less donating group from the chelating ligand in the complexes used in this study. This nominally vacant coordination site opens the possibility for coordination of the substrate to the divalent metal ion even when a hydroxide is formed on this site. The electrostatic stabilization of the bound substrate might be sufficient to allow for the observed rate enhancement for a bimolecular attack of free hydroxides, but a hydroxide that is only coordinated to the divalent metal might be sufficiently reactive to avoid saturation effects even at high $\mathrm{pH}$. 


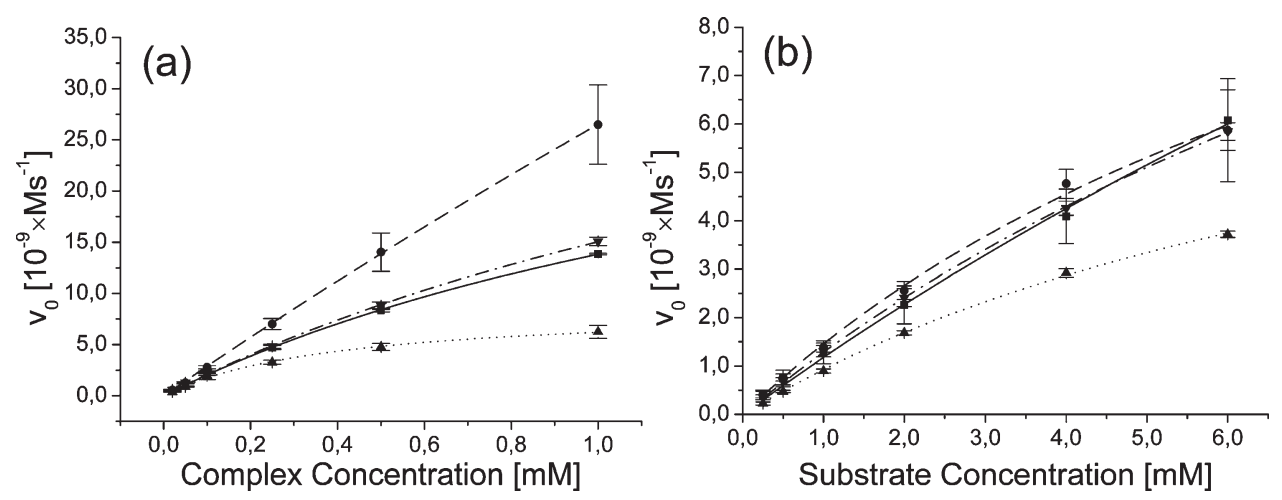

Figure 17. Catalyst (a) and substrate (b) dependence of the initial rates for BDNPP hydrolysis enhanced by $\left[\mathrm{Fe}(\mathrm{III}) \mathrm{M}(\mathrm{II})(\mathrm{IPCPMP})(\mathrm{OAc})_{2}\left(\mathrm{CH}_{3} \mathrm{OH}\right)\right]\left[\mathrm{PF}_{6}\right](\mathrm{M}=\mathrm{Zn}(2) \mathrm{pH} 6.5(\boldsymbol{\square})$, Co pH 6.5 (3) (•), Ni pH $5.5(4)(\mathbf{\Delta})$, and $\mathrm{Mn}(\mathbf{5}) \mathrm{pH} 6.5(\boldsymbol{\nabla})$.

Table 4. Kinetic Parameters Obtained from Fitting of the Michaelis-Menten Equation to the Data in Figure $17 \mathrm{~b}(\mathrm{Zn} 4=$ $\left.\left[\left\{\mathrm{Zn}_{2}(\mathrm{IPCPMP})(\mathbf{O A c})\right\}_{2}\right]\left[\mathrm{PF}_{6}\right]\right)^{47,72}$

\begin{tabular}{|c|c|c|c|c|c|c|}
\hline & $K_{\mathrm{M}}[\mathrm{mM}]$ & $K_{\mathrm{ass}}\left[\mathrm{M}^{-1}\right]^{a}$ & $V_{\max }\left[10^{-8} \mathrm{M} \mathrm{s}^{-1}\right]$ & $k_{\text {cat }}^{b}\left[10^{-4} \mathrm{~s}^{-1}\right]$ & $k_{\mathrm{cat}} / K_{\mathrm{M}}\left[10^{-2} \mathrm{M}^{-1} \mathrm{~s}^{-1}\right]$ & $k_{\text {cat }} / k_{\text {uncat }}{ }^{c}\left[10^{3}\right]$ \\
\hline 2 & 27.8 & 36.0 & 3.38 & 6.76 & 2.43 & 21.1 \\
\hline 3 & 9.80 & 102 & 1.57 & 3.14 & 3.20 & 9.81 \\
\hline 4 & 9.40 & 106 & 0.961 & 1.92 & 2.04 & 6.01 \\
\hline 5 & 14.6 & 68.5 & 2.00 & 4.00 & 2.74 & 12.5 \\
\hline $\mathrm{Zn} 4$ & 17.3 & 57.8 & 3.44 & 6.89 & 3.98 & 21.5 \\
\hline
\end{tabular}

The dependence of the initial rates on the catalyst and substrate concentrations was also investigated, and the results are displayed in Figure 17. At high catalyst concentrations (Figure 17a) there is a clear saturation effect for $2(\mathrm{FeZn}), 4$ $(\mathrm{FeNi})$, and $\mathbf{5}(\mathrm{FeMn})$ while for $\mathbf{3}(\mathrm{FeCo})$ only a very weak effect is visible. This saturation is probably due to a nonfavorable dimerization, possibly via hydroxide bridge(s), or polymerization. Dimerizations of dinuclear $\mathrm{Zn}$ (II) complexes of IPCPMP ${ }^{47}$ and ICIMP $^{83}$ and related $\mathrm{Ni}(\mathrm{II})$ complexes, ${ }^{48,86}$ where two dinuclear entities are bridged through the endogenous carboxylate of the ligand, have been observed previously. A polymerization/dimerization similar to that detected in the solid state structure of 6 (Figure 5) is also possible. In the absence of water (pure acetonitrile), such oligomerizations of the complexes do not appear to take place, as the IR spectra of $\mathbf{2 , 3}$, and $\mathbf{4}$ show that even at $40 \mathrm{mM}$ complex concentration, monodentate and thus nonbridging carboxylates are clearly observed.

The dependence on substrate concentration also shows saturation behavior (Figure 17b), indicating that the substrate binds to the catalyst in a pre-equilibrium step before the nucleophilic attack. The data could be fitted to the Michaelis-Menten equation, yielding $K_{M}, V_{\max }$, and $k_{\text {cat }}$ values as shown in Table 4. Comparison of the $K_{M}$ values indicate that $2(\mathrm{FeZn})$ binds the substrate weaker than $3(\mathrm{FeCo}), 4(\mathrm{FeNi})$, and $5(\mathrm{FeMn})$. The $K_{M}$ values for these heterodinuclear complexes are on the same order although slightly lower than those for analogous complexes of the BPBPMP ligand $(2.1-11 \mathrm{mM}),{ }^{56-60}$ which contains a terminal phenolate donor in the same position as the carboxylate donor of IPCPMP. The stronger binding and better electron-feeding properties of the terminal phenolate might favor the binding of less strong donors such as phosphate monoanions compared to competing carboxylates (acetates). The weak binding of the substrate by 2 can also be compared to the tetranuclear Zinc complex $\left[\left\{\mathrm{Zn}_{2}(\mathrm{IPCPMP})(\mathrm{OAc})\right\}_{2}\right]\left[\mathrm{PF}_{6}\right](\mathrm{Zn} 4),{ }^{47,72}$ which in solution forms isolated dinuclear complexes and also show weak binding of $\operatorname{BDNPP}\left(K_{M}=17.3 \mathrm{M}\right)$. The $k_{\text {cat }}$ values for $\mathbf{2}-\mathbf{5}$ are of similar magnitudes and comparable or slightly lower compared to those for the heterodinuclear complexes of BPBPMP $\left(4.5-18 \times 10^{-4}\right.$ $\left.\mathrm{s}^{-1}\right) \cdot{ }^{56-60}$ The value for $\mathbf{2}$ is slightly higher than that of $\mathbf{3}, \mathbf{4}$, and $\mathbf{5}$, indicating a transition state of lower energy for $\mathbf{2}$. The $k_{\text {cat }}$ value for the latter complex is similar to that for the $\mathrm{Zn}$ (II) complex of IPCPMP (Zn4). ${ }^{47,72}$ However, the Zn(II)-containing complexes appear to bind the substrate less efficiently yielding low overall efficiency $\left(k_{\text {cat }} / K_{M}\right)$, especially for 2 . Complex $2(\mathrm{FeZn})$ still shows highest rate enhancement in the product forming step relative to the uncatalyzed reaction $\left(k_{\text {cat }} / k_{\text {uncat }}\right)$ among the complexes studied here. The overall rate enhancement $\left(v_{i, \text { cat }} / v_{\text {i,uncat }}\right)$ compared to the uncatalyzed reaction (which does not include a binding step of the substrate) is in the range 100-200 except for complex $4(\mathrm{FeNi})$ which reaches a factor of 600 at $\mathrm{pH} 10$. At extended reaction times, the absorbance versus time dependence for $\mathbf{2}(\mathrm{FeZn}), \mathbf{4}(\mathrm{FeNi})$, and $\mathbf{5}(\mathrm{FeMn})$ revealed biphasic behavior (Supporting Information, Figure S5) with relatively abrupt changes in rate (absorbance per unit time) after $5 \mathrm{~h}$, which may be indicative of diesterase activity, that is, hydrolysis of the monoester product formed upon hydrolysis of the BDNPP substrate (cf. Supporting Information).

\section{CONCLUSIONS}

The mononuclear synthon $\left[\mathrm{Fe}(\mathrm{III})\left(\mathrm{H}_{2} \mathrm{IPCPMP}\right)\left(\mathrm{Cl}_{2}\right)\right]$ $\left[\mathrm{PF}_{6}\right](1),{ }^{49}$ generated in situ, has been used to systematically produce heterodinuclear complexes of the formulas 
$\left[\mathrm{Fe}(\mathrm{III}) \mathrm{M}(\mathrm{II})(\mathrm{IPCPMP})(\mathrm{OAc})_{2}\left(\mathrm{CH}_{3} \mathrm{OH}\right)\right]\left[\mathrm{PF}_{6}\right](\mathrm{M}=\mathrm{Zn}$ (2), Co (3), Ni (4), Mn (5)), [Fe(III) Zn(II)(IPCPMP)(mpdp)][PF $]$ (6), and $[\mathrm{Fe}(\mathrm{III}) \mathrm{Cu}(\mathrm{II})(\mathrm{IPCPMP})(\mathrm{OAc})\}_{2^{-}}$ $(\mu-\mathrm{O})]\left[\mathrm{PF}_{6}\right](7)$. All complexes except 5 have been characterized by crystallography, revealing virtually identical structures for 2-4. On the basis of the physical and spectroscopic properties of 5, as determined by IR, Mössbauer, ESI-MS, and magnetic susceptibility measurements, it can be assumed to have the same structure as $\mathbf{2 - 4}$ in the solid state. Complex $\mathbf{6}$ is a heteronuclear coordination polymer in the solid state consisting of heterodinuclear monomers, while 7 forms a dimer of dimer structure of two heterodinuclear [ $\mathrm{Fe}(\mathrm{III}) \mathrm{Cu}(\mathrm{II})(\mathrm{IPCPMP})(\mathrm{OAc})]$ bridged by a $\mu$-oxido group between the two $\mathrm{Fe}$ (III).

Infrared spectroscopy confirmed that the Fe(III) is selectively bound in the tetradentate pocket for 2-4 with monodentate coordination of the endogenous carboxylate of IPCPMP. The structure is retained in acetonitrile solution as observed by both IR and ESI MS, but in aqueous solution mass spectrometry indicates that the acetate bridges may be substituted for hydroxides and that $\mathbf{2 - 4}$ partly dissociate into mononuclear Fe(III) complexes. Complete dissociation is observed for $\mathbf{5}$ under these conditions.

Electronic spectroscopy over a wide $\mathrm{pH}$ range indicates a clean conversion of one species to another for $\mathbf{4}$ and $\mathbf{5}$; the latter species is proposed to be a $\mu$-hydroxido bridged heterodinuclear complex. The same species is probably observed as an intermediate for 2 and 3 before forming a $\mu$-oxido bridged dimer of dimer of similar structure to 7 .

Mössbauer spectra show that $\mathbf{1}, \mathbf{3}$, and 5 contain high spin $\mathrm{Fe}$ (III) while no parameters could be extracted for $\mathbf{2}$ and 4 because of relaxation effects. Magnetic susceptibility measurements support the designation of $\mathbf{2}-\mathbf{5}$ as being $\mathrm{Fe}(\mathrm{III}) \mathrm{M}(\mathrm{II})(\mathrm{M}=$ Zn, Co (high spin), Ni (high spin), Mn (high spin)).

Complexes $2-5$ are active toward phosphoester cleavage for both HPNP (an RNA mimic) and BDNPP (a DNA mimic) but display considerable differences in reactivity. For the HPNP reaction complex 2 shows very low activity, which is probably due to the formation of the $\mu$-oxido bridged dimer of dimer at higher $\mathrm{pH}$. Complex 3 is the most active for HPNP transesterification but shows no saturation effects, indicating that either the hydroxy functionality of the substrate is not coordinated to a metal (and deprotonated before the attack) or that the deprotonation of the coordinated hydroxyl group and its attack on the substrate is a concerted process (Scheme 2a). A similar mechanism for $\mathbf{5}$, which is less active, can be invoked. For complex 4 a saturation behavior is observed, and the mechanism here likely involves coordination and deprotonation of the hydroxyl group before its attack on the phosphorus center (Scheme $2 \mathrm{~b}$ ), although pre-equilibrium deprotonation of a water molecule coordinated to the $\mathrm{Ni}$ (II) can not be excluded (Scheme 2c).

For BDNPP hydrolysis by $\mathbf{2}-\mathbf{5}$ different mechanisms are observed at low and high $\mathrm{pH}$, respectively. For 2, 3, and 5 at low $\mathrm{pH}$, the mechanism is proposed to involve an attack by a hydroxide coordinated terminally to $\mathrm{Fe}$ (III) (Scheme $2 \mathrm{~d}$ or e) or, alternatively, activation by a water molecule in the second coordination sphere by this hydroxide. For $\mathbf{4}$ a noncoordinated water molecule is the more probable nucleophile (Scheme $2 \mathrm{f}$ ). At high $\mathrm{pH}, 2$ shows very low activity, again probably because of the formation of a $\mu$-oxido dimer of dimer, while 3-5 display an increase in activity. This increase in activity may be due to a mechanism where a noncoordinated hydroxide acts as nucleophile (Scheme 2f). A dimerization process for 2, 4, and 5 probably inhibits the BDNPP hydrolysis at high complex concentrations. An analysis of the substrate dependence using Michaelis-Menten kinetics shows that BDNPP binds weaker to 2 than 3-5 prior to hydrolysis, possibly indicating a different coordination mode of the substrate in the former case. The overall efficiencies of the complexes are, however, comparable to previously studied systems. ${ }^{56-60}$

Further studies are directed toward elucidating the species distribution under conditions relevant for phosphoester hydrolysis, as well as studying the complexes in solution by EPR and EXAFS to get structural information on the species that are active in the reactions.

\section{EXPERIMENTAL SECTION}

General Methods. All solvents were of at least $99.5 \%$ purity and used as received or dried either by distillation from $\mathrm{CaH}_{2}$ (methanol, 2-propanol) or by keeping over $3 \AA$ molecular sieves in a sealed bottle overnight (acetone). Reagents were of at least $99 \%$ purity and used as received. The bis-hexafluorophosphate salt of the ligand 2- $(\mathrm{N}$ isopropyl- $N$-((2-pyridyl)methyl)aminomethyl)-6-( $N$-(carboxylmethyl)$\mathrm{N}$-((2-pyridyl)-methyl)aminomethyl)-4-methylphenol ( $\mathrm{H}_{4} \mathrm{IPCPMP}-$ $\left(\mathrm{PF}_{6}\right)_{2} \cdot \mathrm{H}_{2} \mathrm{O}$ or $\mathrm{H}_{4} \mathrm{~L}$ ) was synthesized as described elsewhere. ${ }^{72}$

Physical Methods. UV-vis spectroscopy and kinetic measurements were performed on a Varian $300 \mathrm{Bio} \mathrm{UV} /$ vis spectrophotometer equipped with a 12-position thermostatted cell changer. Infrared spectra were collected on a Nicolet Avatar 360 FT-IR spectrometer for solid KBr discs and a Digilab Excalibur FTIR spectrometer equipped with an Axiom Analytical DPR-210 dipper system and a MCT detector for liquid samples. ESI-MS were collected on a Waters Micromass ZQ 4000 probe with capillary potential $3.5 \mathrm{Kvolts}$, source cone $20-25 \mathrm{~V}$, source temperature $70^{\circ} \mathrm{C}$, and direct infusion of $20 \mu \mathrm{L} / \mathrm{min}$. FAB mass spectra were collected on a JEOL SX-102 spectrometer with 2-nitrobenzyl alcohol (NBA) as matrix. All mass spectrometry data are reported as $m / z$ with probable species, and the relative intensity of the peaks in $\%$ based on the $\mathrm{Fe}^{56}$ and $\mathrm{Zn}^{64}$ isotope given within brackets.

Synthesis of Complexes. For the heterodinuclear complexes only representative large scale procedures are presented, demonstrating the two methods (A and B).

$\left[\mathrm{Fe}\left(\mathrm{H}_{2} / \mathrm{PCPMP}\right) \mathrm{Cl}_{2}\right]\left[\mathrm{PF}_{6}\right]$ (1). To a solution of $68.4 \mathrm{mg}(0.42 \mathrm{mmol})$ $\mathrm{FeCl}_{3}$ in $4 \mathrm{~mL}$ of dry acetonitrile was added $295.6 \mathrm{mg}(0.39 \mathrm{mmol})$ of $\mathrm{H}_{4} \mathrm{IPCPMP}\left(\mathrm{PF}_{6}\right)_{2} \cdot \mathrm{H}_{2} \mathrm{O}\left(\mathrm{H}_{4} \mathrm{~L}\right)$, and the color turned intensely bluepurple. After stirring at room temperature for $2 \mathrm{~h}$, butyl acetate was added until complete precipitation of a purple solid, which was isolated by centrifugation and washed with more butyl acetate. The solid was recrystallized from acetone/butyl acetate $2: 1(\mathrm{v} / \mathrm{v})$ by slow evaporation yielding $170.2 \mathrm{mg}(60.1 \%)$

Elem. Anal. $\mathrm{C}_{27} \mathrm{H}_{35} \mathrm{Cl}_{2} \mathrm{~F}_{6} \mathrm{FeN}_{4} \mathrm{O}_{3} \mathrm{P}$ \%Calc. C, 44.10; $\mathrm{H}, 4.80 ; \mathrm{N}$, 7.62; Found: C, 44.48; H, 4.26; N, 8.10; FAB-MS+ $m / z 560$ $\left([\mathrm{Fe}(\mathrm{IPCPMP}) \mathrm{Cl}]+\mathrm{Na}^{+}, 100\right), 538\left([\mathrm{Fe}(\mathrm{IPCPMP}) \mathrm{Cl}]+\mathrm{H}^{+}, 60\right)$; IR $\left(\mathrm{KBr}, \mathrm{cm}^{-1}\right)$ 3095(m), 1662(s, $-\mathrm{CO}_{2}$ antisym.), 1621(s, C=C arom.), $1582(\mathrm{~s}, \mathrm{C}=\mathrm{C}$ arom.), $1476(\mathrm{~s}, \mathrm{C}=\mathrm{C}$ arom. $), 1449(\mathrm{~m})$, 1407(m), 1388(m), 1260(s, sym.), 842(vs, $\left.\mathrm{PF}_{6}\right), 769\left(\mathrm{~s}, \mathrm{PF}_{6}\right), 577(\mathrm{~s})$; $\mathrm{UV} /$ vis acetonitrile, $\mathrm{nm},(\varepsilon) 557\left(1302 \mathrm{M}^{-1} \mathrm{~cm}^{-1}\right), 358$ (4061 $\left.\mathrm{M}^{-1} \mathrm{~cm}^{-1}\right), 296\left(9228 \mathrm{M}^{-1} \mathrm{~cm}^{-1}\right), 254\left(14405 \mathrm{M}^{-1} \mathrm{~cm}^{-1}\right)$

$\left[\mathrm{FeZn}(\mathrm{IPCPMP})(\mathrm{OAC})_{2}\left(\mathrm{CH}_{3} \mathrm{OH}\right)\right]\left[\mathrm{PF}_{6}\right]$ (2)

Method $B$ - Deprotonation by Excess Sodium Acetate and Filtering through Celite. A total of $151.2 \mathrm{mg}$ of $\mathbf{H}_{\mathbf{4}} \mathbf{L}(0.20 \mathrm{mmol})$ was dissolved in $3 \mathrm{~mL}$ of a $1: 1(\mathrm{v} / \mathrm{v})$ methanol/acetone mixture, and $33.8 \mathrm{mg}$ of $\mathrm{FeCl}_{3}(0.208 \mathrm{mmol})$ was added to this solution, whereupon the color turned intensely blue-purple (and a few dark blue crystals were formed). No visible change occurred when $46.0 \mathrm{mg}(0.21 \mathrm{mmol})$ 
$\mathrm{Zn}(\mathrm{OAc})_{2} \cdot 2 \mathrm{H}_{2} \mathrm{O}$ was added, but upon stepwise addition of $12.4 \mathrm{~mL}$ of a $0.1 \mathrm{M}$ sodium acetate $(1.24 \mathrm{mmol})$ solution in methanol, the color gradually changed to pink-red. After stirring for $3 \mathrm{~h}$ at room temperature, all solvent was removed to yield a pink-purple oily residue that was dissolved in acetone and filtered through Celite to remove the sodium salts formed. The filtrate was evaporated, and the residue was recrystallized from methanol/2-propanol $(3: 1 \mathrm{v} / \mathrm{v})$ by slow evaporation. This yielded $120 \mathrm{mg}(66.7 \%)$ of small dark pink crystals.

Elem. Anal. [FeZn(IPCPMP $\left.)(\mathrm{OAc})_{2}\left(\mathrm{CH}_{3} \mathrm{OH}\right)\right] \mathrm{PF}_{6} \mathrm{C}_{31} \mathrm{H}_{40} \mathrm{~F}_{6} \mathrm{Fe}-$ $\mathrm{N}_{4} \mathrm{O}_{8} \mathrm{PZn}$ Calc. C, 43.15; H, 4.67; N, 6.49; Found: C, $42.53 \mathrm{H}, 4.5 \mathrm{~N}$, 6.45; FAB-MS $+m / z 684\left(\left[\mathrm{FeZn}(\mathrm{IPCPMP})(\mathrm{OAc})_{2}\right]^{+}, 100\right), 625$ $\left([\mathrm{FeZn}(\mathrm{IPCPMP})(\mathrm{OAc})]^{+}, 60\right) ;$ ESI-MS + , acetonitrile, $\mathrm{m} / z 684$ $\left(\left[\mathrm{FeZn}(\mathrm{IPCPMP})(\mathrm{OAc})_{2}\right]^{+}, 100\right)$; water/acetonitrile $1: 1(\mathrm{v} / \mathrm{v}) \mathrm{m} / \mathrm{z}$ $642\left([\mathrm{FeZn}(\mathrm{IPCPMP})(\mathrm{OAc})(\mathrm{OH})]^{+}, 80\right), 582$ ([FeZn(IPCPMP)$\left.(\mathrm{O})]^{+}, 100\right), 502\left([\mathrm{Fe}(\mathrm{IPCPMP})]^{+}, 95\right) ; \mathrm{IR}\left(\mathrm{KBr}, \mathrm{cm}^{-1}\right) 2968(\mathrm{w})$, 2926(w), 2852(w), 2825(w), 1655(m, terminal $-\mathrm{CO}_{2}$ antisym.), 1607(s, bridg.- $\mathrm{CO}_{2}$ antisym.), 1476(w, $\mathrm{C}=\mathrm{C}$ arom.), 1419 (m,br, bridg. $-\mathrm{CO}_{2}$ sym.), $1342\left(\mathrm{~m}\right.$, terminal $-\mathrm{CO}_{2}$ sym. $), 1264(\mathrm{w}), 1155(\mathrm{w})$, 1023(m), 841(vs, $\left.\mathrm{PF}_{6}\right), 556(\mathrm{~m}) ; \mathrm{UV} /$ vis acetonitrile $\mathrm{nm}(\varepsilon) 494(\mathrm{br}$, $\left.1375 \mathrm{M}^{-1} \mathrm{~cm}^{-1}\right), 288\left(15654 \mathrm{M}^{-1} \mathrm{~cm}^{-1}\right), 257\left(24695 \mathrm{M}^{-1} \mathrm{~cm}^{-1}\right)$

$\left[\mathrm{FeCO}(\mathrm{IPCPMP})(\mathrm{OAC})_{2}\left(\mathrm{CH}_{3} \mathrm{OH}\right)\right]\left[\mathrm{PF}_{6}\right]$ (3)

Method A - Deprotonation with Tributyl Amine. To $199.9 \mathrm{mg}$ (0.264 mmol) of $\mathrm{H}_{4} \mathrm{IPCPMP}\left(\mathrm{PF}_{6}\right)_{2} \cdot \mathrm{H}_{2} \mathrm{O}$ dissolved in $4 \mathrm{~mL}$ of methanol and $1 \mathrm{~mL}$ of acetonitrile was added $42.8 \mathrm{mg}(0.26 \mathrm{mmol})$ of $\mathrm{FeCl}_{3}$ dissolved in $2 \mathrm{~mL}$ of methanol, and the solution turned intensely blue-purple. Then $65.7 \mathrm{mg}(0.26 \mathrm{mmol})$ of $\mathrm{Co}(\mathrm{OAc})_{2} \cdot 4 \mathrm{H}_{2} \mathrm{O}$ was added dissolved in $2 \mathrm{~mL}$ of methanol, but no visible change occurred until 4 equiv $(252 \mu \mathrm{L}, 1.06 \mathrm{mmol})$ of tributyl amine was added dropwise, whereupon the color changed to pink-red. About $1 \mathrm{~mL}$ of 2-propanol was added, and the solution was left to slowly evaporate which over a few days yielded $196 \mathrm{mg}$ (86.7\%) of dark purple crystals of X-ray quality.

Elem. Anal. [FeCo(IPCPMP $\left.)(\mathrm{OAc})_{2}\left(\mathrm{CH}_{3} \mathrm{OH}\right)\right]\left[\mathrm{PF}_{6}\right] \cdot \mathrm{CH}_{3} \mathrm{OH}$ $\mathrm{C}_{32} \mathrm{H}_{44} \mathrm{CoF}_{6} \mathrm{FeN}_{4} \mathrm{O}_{9} \mathrm{P}$ \%Calc. C, 43.26; H, 4.99; N, 6.31; Found C, 43.83; H, 5.69; N 6.40; FAB-MS $m / z 679$ ([FeCo(IPCPMP) $\left.(\mathrm{OAc})_{2}\right]^{+}$, 100), $620\left([\mathrm{FeCo}(\mathrm{IPCPMP})(\mathrm{OAc})]^{+}, 60\right)$; ESI-MS acetonitrile $\mathrm{m} / \mathrm{z}$ $679\left(\left[\mathrm{FeZn}(\mathrm{IPCPMP})(\mathrm{OAc})_{2}\right]^{+}, 100\right) ;$ Water/acetonitrile 1:1 (v/v) $m / z \quad 637\left([\mathrm{FeCo}(\mathrm{IPCPMP})(\mathrm{OAc})(\mathrm{OH})]^{+}, 40\right), 595 \quad([\mathrm{FeCo}-$ $\left.\left.(\mathrm{IPCPMP})(\mathrm{OH})_{2}\right]^{+}, 55\right), 577\left([\mathrm{FeCo}(\mathrm{IPCPMP})(\mathrm{O})]^{+}, 100\right), 502$ $\left([\mathrm{Fe}(\mathrm{IPCPMP})]^{+}, 50\right) \mathrm{IR}\left(\mathrm{KBr}, \mathrm{cm}^{-1}\right) 2968(\mathrm{w}), 2926(\mathrm{w}), 2854(\mathrm{w})$, 2823(w), $1657\left(\mathrm{~m}\right.$, terminal $-\mathrm{CO}_{2}$ antisym.), 1607 (s, bridg. $-\mathrm{CO}_{2}$ antisym.), $1476\left(\mathrm{w}, \mathrm{C}=\mathrm{C}\right.$ arom.), $1412\left(\mathrm{~m}, \mathrm{br}\right.$, bridg. $-\mathrm{CO}_{2}$ sym.), 1341(m, terminal $-\mathrm{CO}_{2}$ sym.), 1265(w), 1155(w), 1023(m), 841(vs), $555(\mathrm{~m}) ; \mathrm{UV} /$ vis acetonitrile $\mathrm{nm} 491\left(1440 \mathrm{M}^{-1} \mathrm{~cm}^{-1}\right), 288(16000$ $\left.\mathrm{M}^{-1} \mathrm{~cm}^{-1}\right), 257\left(23500 \mathrm{M}^{-1} \mathrm{~cm}^{-1}\right)$

[FeNi(IPCPMP) $\left.(\mathrm{OAC})_{2}\left(\mathrm{CH}_{3} \mathrm{OH}\right)\right]\left[\mathrm{PF}_{6}\right]$ (4). This complex was synthesized using method $\mathrm{B}$ and the same procedure used for $\mathbf{2}$ (vide supra) starting from $147.4 \mathrm{mg}(0.20 \mathrm{mmol}) \mathrm{H}_{4} \mathrm{~L}, 32.9 \mathrm{mg}(0.20 \mathrm{mmol})$ of $\mathrm{FeCl}_{3}, 50.5 \mathrm{mg}(0.203 \mathrm{mmol})$ of $\mathrm{Ni}(\mathrm{OAc})_{2} \cdot 4 \mathrm{H}_{2} \mathrm{O}$, and $12.4 \mathrm{~mL}$ of a 0.1 $\mathrm{M}$ sodium acetate $(1.24 \mathrm{mmol})$ solution in methanol. Yielded $101 \mathrm{mg}$ (58.1\%) of small dark pink crystals.

Elem. Anal. [FeNi(IPCPMP $\left.)(\mathrm{OAc})_{2}\left(\mathrm{CH}_{3} \mathrm{OH}\right)\right] \mathrm{PF}_{6} \mathrm{C}_{31} \mathrm{H}_{40} \mathrm{~F}_{6} \mathrm{FeN}_{4}$. $\mathrm{NiO}_{8} \mathrm{P}$ \%Calc. C, 43.49; H, 4.71; N, 6.54; Found C, 43.07; H, 4.50; N, 6.47; FAB-MS $+m / z 679\left(\left[\mathrm{FeNi}(\mathrm{IPCPMP})(\mathrm{OAc})_{2}\right]^{+}, 100\right), 620$ $\left([\mathrm{FeNi}(\mathrm{IPCPMP})(\mathrm{OAc})]^{+}, 60\right) ;$ ESI-MS + acetonitrile $\mathrm{m} / z 679$ $\left(\left[\mathrm{FeNi}(\mathrm{IPCPMP})(\mathrm{OAc})_{2}\right]^{+}, 100\right), 1383\left([\mathrm{FeNi}(\mathrm{IPCPMP})(\mathrm{OAc})]_{2^{-}}\right.$ $\left.\left.+\mathrm{PF}_{6}\right\}^{+}, 1\right)$; Water/acetonitrile $1: 1 \mathrm{~m} / z$ 636 ([FeNi(IPCPMP)$\left.(\mathrm{OAc})(\mathrm{OH})]^{+}, 100\right), 577\left([\mathrm{FeNi}(\mathrm{IPCPMP})(\mathrm{O})]^{+}, \quad 80\right), 502$ $\left([\mathrm{Fe}(\mathrm{IPCPMP})]^{+}, 20\right) \mathrm{IR}\left(\mathrm{KBr}, \mathrm{cm}^{-1}\right) 2969(\mathrm{w}), 2924(\mathrm{w}), 2855(\mathrm{w})$, $2825(\mathrm{w}), 1653\left(\mathrm{~m}\right.$, terminal $-\mathrm{CO}_{2}$ antisym.), 1608 (s, bridg. $\mathrm{CO}_{2}$ antisym.), 1477 (w, $\mathrm{C}=\mathrm{C}$ arom.), $1414\left(\mathrm{~m}\right.$, br, bridg. $-\mathrm{CO}_{2}$ sym. $), 1344(\mathrm{~m}$, terminal $-\mathrm{CO}_{2}$ sym.), $1265(\mathrm{w}), 1150(\mathrm{w}), 1025(\mathrm{~m}), 842(\mathrm{vs}), 558(\mathrm{~m})$; $\mathrm{UV} /$ vis acetonitrile $\mathrm{nm} 494\left(\begin{array}{llll}1410 & \left.\mathrm{M}^{-1} \mathrm{~cm}^{-1}\right), 288(16000\end{array}\right.$ $\left.\mathrm{M}^{-1} \mathrm{~cm}^{-1}\right), 257\left(24300 \mathrm{M}^{-1} \mathrm{~cm}^{-1}\right)$ $\left[\right.$ FeMn $\left.(I P C P M P)(O A C)_{2}\left(\mathrm{CH}_{3} \mathrm{OH}\right)\right]\left[\mathrm{PF}_{6}\right]$ (5). This complex was synthesized using method $\mathrm{B}$ and the same procedure used for $\mathbf{2}$ (vide supra) but under inert atmosphere using Schlenk techniques and degassed solvents starting from $161.9 \mathrm{mg}(0.214 \mathrm{mmol}) \mathrm{H}_{4} \mathrm{~L}, 34.6 \mathrm{mg}(0.213 \mathrm{mmol})$ of $\mathrm{FeCl}_{3}, 52.3 \mathrm{mg}(0.213 \mathrm{mmol})$ of $\mathrm{Mn}(\mathrm{OAc})_{2} \cdot 4 \mathrm{H}_{2} \mathrm{O}$, and $2.6 \mathrm{~mL}(1.3$ $\mathrm{mmol}$ ) of a $0.5 \mathrm{M}$ degassed sodium acetate solution. Yielded $158.2 \mathrm{mg}$ (87\%) of a dark purple solid.

Elem. Anal. [FeMn(IPCPMP $\left.)(\mathrm{OAc})_{2}\left(\mathrm{CH}_{3} \mathrm{OH}\right)\right]\left[\mathrm{PF}_{6}\right] \mathrm{C}_{31} \mathrm{H}_{40} \mathrm{~F}_{6}$ FeMnN ${ }_{4} \mathrm{O}_{8} \mathrm{P}$ \%Calc. C, 43.68; H, 4.73; N, 6.57 Found C, 42.87; H, 4.23; N, 6.59; FAB-MS $+m / z 675\left(\left[\mathrm{FeZn}(\mathrm{IPCPMP})(\mathrm{OAc})_{2}\right]^{+}, 100\right)$, $616\left([\mathrm{FeZn}(\mathrm{IPCPMP})(\mathrm{OAc})]^{+}, 60\right)$; ESI MS + acetonitrile $\mathrm{m} / z 675$ $\left(\left[\mathrm{FeZn}(\mathrm{IPCPMP})(\mathrm{OAc})_{2}\right]^{+}, 100\right)$; water/acetonitrile $1: 1 \mathrm{~m} / \mathrm{z} 502$ $\left([\mathrm{Fe}(\mathrm{IPCPMP})]^{+}, 100\right)$ IR $\left(\mathrm{KBr}, \mathrm{cm}^{-1}\right)$ 2969(w), 2928(w), 2854(w), 1654(m, terminal $-\mathrm{CO}_{2}$ antisym.), 1606 (s, bridg. $-\mathrm{CO}_{2}$ antisym.), 1475 (w, $\mathrm{C}=\mathrm{C}$ arom.), 1419 (m, bridg. $-\mathrm{CO}_{2}$ sym.), 1387 (m), 1342(m, terminal $-\mathrm{CO}_{2}$ sym.), 1255(w), 1153(w), 1021(m), 841(vs), 558(m); UV/vis acetonitrile $\mathrm{nm} 512\left(802 \mathrm{M}^{-1} \mathrm{~cm}^{-1}\right), 422(707$ $\left.\mathrm{M}^{-1} \mathrm{~cm}^{-1}\right), 357\left(1440 \mathrm{M}^{-1} \mathrm{~cm}^{-1}\right), 284\left(8380 \mathrm{M}^{-1} \mathrm{~cm}^{-1}\right), 258(10$ $\left.800 \mathrm{M}^{-1} \mathrm{~cm}^{-1}\right)$

$[\mathrm{FeZn}(I P C P M P)(\mathrm{mpdp})]\left[\mathrm{PF}_{6}\right](6)$. A total of $31.0 \mathrm{mg}(0.041 \mathrm{mmol})$ of $\mathrm{H}_{4} \mathrm{IPCPMP}\left(\mathrm{PF}_{6}\right)_{2} \cdot \mathrm{H}_{2} \mathrm{O}$ was dissolved in $0.5 \mathrm{~mL}$ of methanol and a few drops of acetonitrile. To this solution, $6.8 \mathrm{mg}$ (0.042 mmol) of $\mathrm{FeCl}_{3}$ dissolved in $0.3 \mathrm{~mL}$ of methanol was added, and the color turned intensely blue purple. No change occurred when $5.7 \mathrm{mg}(0.042 \mathrm{mmol})$ of $\mathrm{ZnCl}_{2}$ and $9.1 \mathrm{mg}$ of $\mathrm{H}_{2} \mathrm{mpdp}$, both dissolved in $0.3 \mathrm{~mL}$ of methanol each, were added to the solution, but when $58.7 \mu \mathrm{L}(0.25 \mathrm{mmol})$ of tributyl amine was added in portions, the color changed to deep red. One milliliter of 2-propanol was added before filtering the solution and leaving it to slowly evaporate which yielded crystals of X-ray diffraction quality.

FAB-MS $m / z$ (rel. intensity, \%) 787 ([FeZn(IPCPMP)(mpdp) $]^{+}$, 100); ESI-MS + (methanol) $\mathrm{m} / z$ (rel. intensity, \%) 786 ([FeZn$\left.(\mathrm{IPCPMP})(\mathrm{mpdp})]^{+}, 100\right)$.

$\left.[F e C u(I P C P M P)(O A C)\}_{2}(\mu-O)\right]\left[P F_{6}\right]_{2}(7)$. This complex was synthesized using method $\mathrm{B}$ and the same procedure used for 3 (vide supra), starting from $200.1 \mathrm{mg}(0.26 \mathrm{mmol})$ of $\mathbf{H}_{4} \mathbf{L}, 42.7 \mathrm{mg}(0.26 \mathrm{mmol})$ of $\mathrm{FeCl}_{3}, 52.7 \mathrm{mg}(0.26 \mathrm{mmol})$ of $\mathrm{Cu}(\mathrm{OAc})_{2} \cdot \mathrm{H}_{2} \mathrm{O}$, and $377 \mu \mathrm{L}$ of tributyl amine $(1.58 \mathrm{mmol})$. The reaction yielded a brown solid that had to be crystallized from acetone/water $4: 1(\mathrm{v} / \mathrm{v})$ by slow evaporation which gave $20 \mathrm{mg}(5 \%)$ of a brown solid.

Elem. Anal. $\left\{[\mathrm{FeCu}(\mathrm{IPCPMP})(\mathrm{OAc})]_{2}(\mathrm{O})\right\}\left(\mathrm{PF}_{6}\right)_{2} \mathrm{C}_{56} \mathrm{H}_{66} \mathrm{Cu}_{2} \mathrm{~F}_{12}$ $\mathrm{Fe}_{2} \mathrm{~N}_{8} \mathrm{O}_{11} \mathrm{P}_{2}$ \%Calc. C, 43.23; H, 4.28; N, 7.20; Found: 42.44, H 4.34, N 7.21 ; FAB-MS $+m / z 1410\left([\mathrm{FeCu}(\mathrm{IPCPMP})(\mathrm{OAc})\}_{2}(\mu-\mathrm{O})\right]^{+}+$ $\left.\left.\mathrm{PF}_{6}{ }^{-}, 30\right), 1284\left([\mathrm{FeCu}(\mathrm{IPCPMP})(\mathrm{OAc})\}_{2}(\mu-\mathrm{O})\right]^{2+}+\mathrm{F}^{-}, 35\right)$, $\left.1266\left([\mathrm{FeCu}(\mathrm{IPCPMP})(\mathrm{OAc})\}_{2}(\mu-\mathrm{O})\right]^{+}, 45\right), 777$ ([FeCu$\left.\left.(\mathrm{IPCPMP})(\mathrm{OAc})_{2}\right]+\mathrm{NBA}-\mathrm{NO}_{2}-\mathrm{OH}, 55\right), 684(([\mathrm{FeCu}-$ $\left.\left.(\mathrm{IPCPMP})(\mathrm{OAc})_{2}\right]^{+}, 30\right), 625\left(\left([\mathrm{FeCu}(\mathrm{IPCPMP})(\mathrm{OAc})]^{+}, 50\right), 582\right.$ $\left([\mathrm{FeCu}(\mathrm{IPCPMP})(\mathrm{O})]^{+}, 100\right), 566\left([\mathrm{FeCu}(\mathrm{IPCPMP})]^{+}, 55\right)$; ESIMS + acetonitrile $m / z \quad 1409 \quad\left([\mathrm{FeCu}(\mathrm{IPCPMP})(\mathrm{OAc})\}_{2^{-}}\right.$ $\left.(\mathrm{O})]^{2+}+\mathrm{PF}_{6}{ }^{-}, 2\right), 632\left(\left[\{\mathrm{FeCu}(\mathrm{IPCPMP})(\mathrm{OAc})\}_{2}(\mathrm{O})\right]^{2+}, 100\right)$. Upon increasing the cone voltage fragments corresponding to $\left.\mathrm{Fe}(\mathrm{III}) \mathrm{Cu}(\mathrm{II})(\mathrm{IPCPMP})(\mathrm{OAc})_{2}\right]^{+}(m / z=683), \quad[\mathrm{Fe}(\mathrm{III}) \mathrm{Cu}(\mathrm{II})-$ $(\mathrm{IPCPMP})(\mathrm{O})]^{+}(m / z=581)$, and $[\mathrm{Fe}(\mathrm{III}) \mathrm{Cu}(\mathrm{II})(\mathrm{IPCPMP})-$ $(\mathrm{OAc})(\mathrm{O})(\mathrm{F})]^{+}(m / z=1283)$ appear, which are reasonable fragmentation products from the $\mu$-oxido complex (7). Water/acetonitrile $m / z 599$ $\left(\left[\mathrm{FeCu}(\mathrm{IPCPMP})(\mathrm{OH})_{2}\right]^{+}, \quad 100\right), 590\left([\mathrm{FeCu}(\mathrm{IPCPMP})(\mathrm{OH})\}_{2^{-}}\right.$ $\left.(\mathrm{O})]^{2+}, 40\right), 581\left([\mathrm{FeCu}(\operatorname{IPCPMP})(\mathrm{O})]^{+}, 90\right) . \mathrm{IR}\left(\mathrm{KBr}, \mathrm{cm}^{-1}\right)$ $2920(\mathrm{w}), 1660\left(\mathrm{~s}\right.$, terminal $-\mathrm{CO}_{2}$ antisym.), 1610(m), 1554(s, bridg. $-\mathrm{CO}_{2}$ antisym.), 1479 (s, $\mathrm{C}=\mathrm{C}$ arom.), 1446 (s, bridg. $-\mathrm{CO}_{2}$ sym.), 1321 (m, terminal $-\mathrm{CO}_{2}$ sym.), 1294(w), 1022(w), 847(vs), 559(s); UV/vis acetonitrile nm $565\left(\mathrm{sh}, 741 \mathrm{M}^{-1} \mathrm{~s}^{-1}\right), 415(2520$ $\left.\mathrm{M}^{-1} \mathrm{~cm}^{-1}\right), 336\left(\mathrm{sh}, 10000 \mathrm{M}^{-1} \mathrm{~cm}^{-1}\right), 280\left(\mathrm{sh}, 19900 \mathrm{M}^{-1} \mathrm{~cm}^{-1}\right)$, $260\left(26700 \mathrm{M}^{-1} \mathrm{~cm}^{-1}\right)$.

Kinetic Measurements. The increase in concentration of the products, $p$-nitrophenolate (PNP) and 2,4-dinitrophenolate (BNP), 
were monitored at $25^{\circ} \mathrm{C}$ by UV/vis spectroscopy at $400 \mathrm{~nm}$ in quartz suprasil cuvettes using a Cary 300 Bio spectrophotometer equipped with a 12-position thermostatted cell changer. For the study of the $\mathrm{pH}$ dependence, substrate and complex concentrations were $0.80 \mathrm{mM}$ and $0.25 \mathrm{mM}$, respectively, and the ionic strength and $\mathrm{pH}$ were kept constant by using total concentrations of $0.1 \mathrm{M} \mathrm{NaClO}_{4}$ and $0.01 \mathrm{M}$ buffer (MES $\mathrm{pH}$ 5-6.5, MOPS 7.0-7.5, EPPS 8.0-8.5, CHES 9.0-9.5, CAPS $10.0-11.0)$. The $\mathrm{pH}$ of the buffer was adjusted in standard solutions using a calibrated $\mathrm{pH}$ meter before addition to the cuvettes. Each cuvette was prepared by consecutive addition of $980 \mu \mathrm{L}$ of acetonitrile, $30 \mu \mathrm{L}$ of a $0.0375 \mathrm{M}$ standard solution of the complex in acetonitrile $/ \mathrm{H}_{2} \mathrm{O}$ $(2: 1 \mathrm{v} / \mathrm{v})$, and $970 \mu \mathrm{L}$ of a $0.0207 \mathrm{M}$ buffer solution containing $0.207 \mathrm{M} \mathrm{NaClO}_{4}$. After mixing, the background absorption was measured. Then $20 \mu \mathrm{L}$ of a $0.080 \mathrm{M}$ standard solution of the substrate in $\mathrm{H}_{2} \mathrm{O}$ was added and after quick mixing the increase in absorption over time was measured at $400 \mathrm{~nm}$, first every minute but after $4 \mathrm{~h}$, every $5 \mathrm{~min}$, and after $8 \mathrm{~h}$, every $15 \mathrm{~min}$. The initial rates were calculated by fitting a straight line to the curve corresponding to abs $<5 \%$ of the maximum absorption at full conversion (usually the first $30 \mathrm{~min}$ ). The dissociation constant of the phenol products $\left(\mathrm{p} K_{\mathrm{a}, \mathrm{PNP}}=7.15\right.$, $\left.\mathrm{p} K_{\mathrm{a}, \mathrm{BNP}}=4.07\right)$ were taken into account when calculating the total concentration of phenol from the absorption of the phenolate at $400 \mathrm{~nm}\left(\varepsilon_{\mathrm{PNP}}=18500 \mathrm{M}^{-1} \mathrm{~cm}^{-1}, \varepsilon_{\mathrm{BNP}}=12100 \mathrm{M}^{-1} \mathrm{~cm}^{-1}\right)$. The absorbance of complex 2 changes over time under the kinetic conditions, and this process occurs over a similar time frame as the HPNP transesterification. At $\mathrm{pH}<6$ this becomes the dominant contribution but could partly be taken into account by subtracting the absorbance versus time data for complex 2 under the same conditions but without the substrate.

Complex and substrate concentration dependence was studied for BDNPP hydrolysis enhanced by [Fe(III)M(II)(IPCPMP)(OAc) $2^{-}$ $\left.\left(\mathrm{CH}_{3} \mathrm{OH}\right)\right]\left[\mathrm{PF}_{6}\right](\mathrm{M}=\mathrm{Zn}(2), \mathrm{Co}(3), \mathrm{Ni}(4)$, and $\mathrm{Mn}(5))$ at $\mathrm{pH} 6.5$ for $\mathbf{2 , 3}$, and 5 and 5.5 for 4 . The measurements and preparations of the solutions in the cuvettes were made as above with total $\mathrm{NaClO}_{4}$ concentration $0.1 \mathrm{M}$ but with total buffer concentration increased to $0.050 \mathrm{M}$. For the dependence on complex concentration different volumes of stock solution of the complexes (2.0 mM in acetonitrile) was added to yield total concentrations of $0.020,0.050,0.1,0.25,0.5$, and $1.0 \mathrm{mM}$ of the complex in the cuvette while keeping the substrate concentration constant at $1.0 \mathrm{mM}$. For the dependence on substrate concentration a similar addition of stock solution of NaBDNPP ( $40.0 \mathrm{mM}$ in water) yielded total concentrations of $0.25,0.5,1.0,2.0$, 4.0 , and $6.0 \mathrm{mM}$ in the cuvette while the complex concentration was kept constant at $0.050 \mathrm{mM}$. Initial rates were calculated as above. The substrate dependence data was analyzed using Michaelis-Menten equation).

Mössbauer Spectroscopy. Mössbauer spectra were recorded with a ${ }^{57} \mathrm{Co}$ source in a $\mathrm{Rh}$ matrix using an alternating constant acceleration Wissel Mössbauer spectrometer operated in the transmission mode and equipped with a Janis closed-cycle helium cryostat. Isomer shifts are given relative to iron metal at ambient temperature. Simulation of the experimental data was performed with the Mfit program. ${ }^{87}$

Magnetic Susceptibility. Magnetic susceptibility measurements were made on a Quantum-Design MPMS-5S SQUID magnetometer equipped with a $5 \mathrm{~T}$ magnet in the range from 2 to $295 \mathrm{~K}$. The powdered samples were contained in a gel bucket and fixed in a nonmagnetic sample holder. Each raw data file for the measured magnetic moment was corrected for the diamagnetic contribution of the sample holder and the sample.

X-ray Structure Determinations. The crystals of 2, 3, 4, 6, and 7 were immersed in cryo-oil, mounted in a Nylon loop, and measured at a temperature of $120 \mathrm{~K}$. The X-ray diffraction data were collected on a Nonius Kappa CCD diffractometer using Mo $K_{\alpha}$ radiation $(\lambda=0.71073 \AA)$.
The Denzo-Scalepack ${ }^{88}$ program package was used for cell refinements and data reductions. The structures were solved by direct methods using the SIR97, ${ }^{89}$ SIR $2004^{90}$ or SHELXS-97 ${ }^{91}$ programs with the WinGX ${ }^{92}$ graphical user interface. A semiempirical absorption correction (XPREP in SHELXTL, ${ }^{93}$ SORTAV $^{94}$ or SADABS ${ }^{95}$ ) was applied to all data. Structural refinements were carried out using SHELXL-97. ${ }^{91}$ In 3 and 4 , four fluorines of the $\mathrm{PF}_{6}$ anion were disordered over two sites with occupancies $0.55 / 0.45$ and $0.6 / 0.4$ respectively. The disordered fluorines were restrained so that their $U_{\mathrm{ij}}$ components approximate isotropic behavior. Furthermore, each disordered pair of fluorines was refined with equal anisotropic displacement factors. In 3, 4, 6, and 7, the $\mathrm{OH}$ hydrogen atoms were located from the difference map but constrained to ride on their parent atom, with $U_{\text {iso }}=$ 1.5. Other hydrogens were positioned geometrically and constrained to ride on their parent atoms, with $\mathrm{C}-\mathrm{H}=0.95-1.00 \AA$ and $U_{\text {iso }}=1.2-1.5$ $U_{\text {eq }}$ (parent atom). The crystallographic details are summarized in Table 1 and selected bond lengths and angles in Table 2 .

\section{ASSOCIATED CONTENT}

S Supporting Information. Crystallographic data in CIF format. Further details are given in Figures S1-S5 and Table S1. This material is available free of charge via the Internet at http:// pubs.acs.org.

\section{AUTHOR INFORMATION}

\section{Corresponding Author}

*E-mail: ebbe.nordlander@chemphys.lu.se.

\section{ACKNOWLEDGMENT}

This research has been supported by a grant from the Swedish Research Council (VR) and the Royal Physiographic Society (www.fysiografen.org) and has been carried out within the framework of the International Research Training Group Metal Sites in Biomolecules: Structures, Regulation and Mechanisms (www.biometals.eu). We thank Dr. Jean-Marc Latour, Commissariat à I'Énergie Atomique (CEA), Grenoble, France, for a generous gift of the ligand mpdp.

\section{REFERENCES}

(1) Holm, R. H.; Kennepohl, P.; Solomon, E. I. Chem. Rev. 1996, 96, 2239-2314.

(2) Burgess, B. K.; Lowe, D. J. Chem. Rev. 1996, 96, 2983-3012.

(3) Howard, J. B.; Rees, D. C. Proc. Natl. Acad. Sci. U.S.A. 2006, 103, 17088-17093.

(4) Solomon, E. I.; Sundaram, U. M.; Machonkin, T. E. Chem. Rev. 1996, 96, 2563-2606.

(5) Sazinsky, M. H.; Lippard, S. J. Acc. Chem. Res. 2006, 39, 558-566.

(6) Fontecilla-Camps, J. C.; Volbeda, A.; Cavazza, C.; Nicolet, Y. Chem. Rev. 2007, 107, 4273-4303.

(7) Solomon, E. I.; Xie, X. J.; Dey, A. Chem. Soc. Rev. 2008, 37, 623-638.

(8) Stenkamp, R. E. Chem. Rev. 1994, 94, 715-726.

(9) Magnus, K. A.; Ton-That, H.; Carpenter, J. E. Chem. Rev. 1994, 94, 727-735.

(10) Dau, H.; Haumann, M. Coord. Chem. Rev. 2008, 252, 273-295.

(11) Renger, G.; Renger, T. Photosynth. Res. 2008, 98, 53-80.

(12) Wilcox, D. E. Chem. Rev. 1996, 96, 2435-2458.

(13) Karplus, P. A.; Pearson, M. A.; Hausinger, R. P. Acc. Chem. Res. 1997, 30, 330-337.

(14) Benini, S.; Rypniewski, W. R.; Wilson, K. S.; Mangani, S.; Ciurli, S. J. Am. Chem. Soc. 2004, 126, 3714-3715. 
(15) Matsui, M.; Fowler, J. H.; Walling, L. L. Biol. Chem. 2006, $387,1535-1544$.

(16) Weston, J. Chem. Rev. 2005, 105, 2151-2174.

(17) Yang, W.; Lee, J. Y.; Nowotny, M. Mol. Cell 2006, 22, 5-13.

(18) Mitic, N.; Smith, S. J.; Neves, A.; Guddat, L. W.; Gahan, L. R.; Schenk, G. Chem. Rev. 2006, 106, 3338-3363.

(19) Twitchett, M. B.; Sykes, A. G. Eur. J. Inorg. Chem. 1999, 2105-2115.

(20) Oddie, G. W.; Schenk, G.; Angel, N. Z.; Walsh, N.; Guddat, L. W.; de Jersey, J.; Cassady, A. I.; Hamilton, S. E.; Hume, D. A. Bone 2000, 27, 575-584.

(21) Nuttleman, P.; Roberts, R. J. Biol. Chem. 1990, 265, $12192-$ 12199.

(22) Cashikar, A. G.; Kumaresan, R.; Rao, N. M. Plant Physiol. 1997, 114, 907-915.

(23) Sträter, N.; Jasper, B.; Scholte, M.; Krebs, B.; Duff, A. P.; Langley, D. B.; Han, R. L.; Averill, B. A.; Freeman, H. C.; Guss, J. M. J. Mol. Biol. 2005, 351, 233-246.

(24) Guddat, L. W.; McAlpine, A. S.; Hume, D.; Hamilton, S.; de Jersey, J.; Martin, J. L. Structure 1999, 7, 757-767.

(25) Lindqvist, Y.; Johansson, E.; Kaija, H.; Vihko, P.; Schneider, G. J. Mol. Biol. 1999, 291, 135-147.

(26) Uppenberg, J.; Lindqvist, F.; Svensson, C.; Ek-Rylander, B.; Andersson, G. J. Mol. Biol. 1999, 290, 201-211.

(27) Sträter, N.; Klabunde, T.; Tucker, P.; Witzel, H.; Krebs, B. Science 1995, 268, 1489-1492.

(28) Klabunde, T.; Sträter, N.; Frohlich, R.; Witzel, H.; Krebs, B. J. Mol. Biol. 1996, 259, 737-748.

(29) Schenk, G.; Gahan, L. R.; Carrington, L. E.; Mitic, N.; Valizadeh, M.; Hamilton, S. E.; de Jersey, J.; Guddat, L. W. Proc. Natl. Acad. Sci. U.S.A. 2005, 102, 273-278.

(30) Beck, J. L.; McConachie, L. A.; Summors, A. C.; Arnold, W. N.; De Jersey, J.; Zerner, B. Biochim. Biophys. Acta 1986, 869, 61-68.

(31) Beck, J. L.; De Jersey, J.; Zerner, B.; Hendrich, M. P.; Debrunner, P. G. J. Am. Chem. Soc. 1988, 110, 3317-3318.

(32) Schenk, G.; Ge, Y.; Carrington, L. E.; Wynne, C. J.; Searle, I. R.; Carroll, B. J.; Hamilton, S.; de Jersey, J. Arch. Biochem. Biophys. 1999, 370, 183-189.

(33) Schenk, G.; Boutchard, C. L.; Carrington, L. E.; Noble, C. J.; Moubaraki, B.; Murray, K. S.; de Jersey, J.; Hanson, G. R.; Hamilton, S. J. Biol. Chem. 2001, 276, 19084-19088.

(34) Smoukov, S. K.; Quaroni, L.; Wang, X.; Doan, P. E.; Hoffman, B. M.; Que, L. J. Am. Chem. Soc. 2002, 124, 2595-2603.

(35) Cox, R. S.; Schenk, G.; Mitic, N.; Gahan, L. R.; Hengge, A. C. J. Am. Chem. Soc. 2007, 129, 9550-9551.

(36) Neves, A.; Lanznaster, M.; Bortoluzzi, A. J.; Peralta, R. A.; Casellato, A.; Castellano, E. E.; Herrald, P.; Riley, M.J.; Schenk, G. J. Am. Chem. Soc. 2007, 129, 7486-7487.

(37) Mitic, N.; Hadler, K. S.; Gahan, L. R.; Hengge, A. C.; Schenk, G. J. Am. Chem. Soc. 2010, 132, 7049-7054.

(38) See the special issue on Biomimetic Inorganic Chemistry. Chem. Rev., 2004, 104, 347-1200.

(39) Gavrilova, A. L.; Bosnich, B. Chem. Rev. 2004, 104, 349-384.

(40) Parkin, G. Chem. Rev. 2004, 104, 699-767.

(41) Meyer, F. Eur. J. Inorg. Chem. 2006, 3789-3800.

(42) Suzuki, M.; Kanatomi, H.; Murase, I. Chem. Lett. 1981, 17451748

(43) Ghiladi, M.; McKenzie, C. J.; Meier, A.; Powell, A. K.; Ulstrup, J.; Wocadlo, S. J. Chem. Soc., Dalton Trans. 1997, 4011-4018.

(44) Albedyhl, S.; Averbuch-Pouchot, M. T.; Belle, C.; Krebs, B.; Pierre, J. L.; Saint-Aman, E.; Torelli, S. Eur. J. Inorg. Chem. 2001, 1457-1464.

(45) Neves, A.; Debrito, M. A.; Drago, V.; Griesar, K.; Haase, W. Inorg. Chim. Acta 1995, 237, 131-135.

(46) Belle, C.; Gautier-Luneau, I.; Karmazin, L.; Pierre, J. L.; Albedyhl, S.; Krebs, B.; Bonin, M. Eur. J. Inorg. Chem. 2002, 3087-3090.

(47) Jarenmark, M.; Kappen, S.; Haukka, M.; Nordlander, E. Dalton Trans. 2008, 993-996.
(48) Carlsson, H.; Haukka, M.; Bousseksou, A.; Latour, J. M.; Nordlander, E. Inorg. Chem. 2004, 43, 8252-8262.

(49) Jarenmark, M.; Carlsson, H.; Trukhan, V. M.; Haukka, M.; Canton, S. E.; Walczak, M.; Fullagar, W.; Sundstrom, V.; Nordlander, E. Inorg. Chem. Commun. 2010, 13, 334-337.

(50) Jarenmark, M.; Carlsson, H.; Haukka, M.; Nordlander, E., unpublished results

(51) Carrell, C. J.; Carrell, H. L.; Erlebacher, J.; Glusker, J. P. J. Am. Chem. Soc. 1988, 110, 8651-8656.

(52) Lambert, E.; Chabut, B.; ChardonNoblat, S.; Deronzier, A.; Chottard, G.; Bousseksou, A.; Tuchagues, J. P.; Laugier, J.; Bardet, M.; Latour, J. M. J. Am. Chem. Soc. 1997, 119, 9424-9437.

(53) Borovik, A. S.; Papaefthymiou, V.; Taylor, L. F.; Anderson, O. P.; Que, L. J. Am. Chem. Soc. 1989, 111, 6183-6195.

(54) Shannon, R. D. Acta Crystallogr., Sect. A 1976, 32, 751-767.

(55) Holman, T. R.; Juarez-Garcia, C.; Hendrich, M. P.; Que, L.; Munck, E. J. Am. Chem. Soc. 1990, 112, 7611-7618.

(56) Lanznaster, M.; Neves, A.; Bortoluzzi, A. J.; Aires, V. V. E.; Szpoganicz, B.; Terenzi, H.; Severino, P. C.; Fuller, J. M.; Drew, S. C.; Gahan, L. R.; Hanson, G. R.; Riley, M. J.; Schenk, G. J. Biol. Inorg. Chem. 2005, 10, 319-332.

(57) Batista, S. C.; Neves, A.; Bortoluzzi, A. J.; Vencato, I.; Peralta, R. A.; Szpoganicz, B.; Aires, V. V. E.; Terenzi, H.; Severino, P. C. Inorg. Chem. Commun. 2003, 6, 1161-1165.

(58) Lanznaster, M.; Neves, A.; Bortoluzzi, A. J.; Szpoganicz, B.; Schwingel, E. Inorg. Chem. 2002, 41, 5641-5643.

(59) Karsten, P.; Neves, A.; Bortoluzzi, A. J.; Lanznaster, M.; Drago, V. Inorg. Chem. 2002, 41, 4624-4626.

(60) Xavier, F. R.; Neves, A.; Casellato, A.; Peralta, R. A.; Bortoluzzi, A. J.; Szpoganicz, B.; Severino, P. C.; Terenzi, H. n.; Tomkowicz, Z.; Ostrovsky, S.; Haase, W.; Ozarowski, A.; Krzystek, J.; Telser, J.; Schenk, G.; Gahan, L. R. Inorg. Chem. 2009, 48, 7905-7921.

(61) Holman, T. R.; Andersen, K. A.; Anderson, O. P.; Hendrich, M. P.; Juarez-Garcia, C.; Munck, E.; Que, L., Jr. Angew. Chem. 1990, $102,933-5$

(62) Schepers, K.; Bremer, B.; Krebs, B.; Henkel, G.; Althaus, E.; Mosel, B.; Mueller-Warmuth, W. Angew. Chem. 1990, 102, 582-4.

(63) Jovito, R.; Neves, A.; Bortoluzzi, A. J.; Lanznaster, M.; Drago, V.; Haase, W. Inorg. Chem. Commun. 2005, 8, 323-327.

(64) Ghiladi, M.; Jensen, K. B.; Jiang, J. Z.; McKenzie, C. J.; Morup, S.; Sotofte, I.; Ulstrup, J. J. Chem. Soc., Dalton Trans. 1999, 2675-2681.

(65) Biswas, P.; Ghosh, M.; Dutta, S. K.; Florke, U.; Nag, K. Inorg. Chem. 2006, 45, 4830-4844.

(66) Dutta, S. K.; Werner, R.; Florke, U.; Mohanta, S.; Nanda, K. K.; Haase, W.; Nag, K. Inorg. Chem. 1996, 35, 2292-2300.

(67) Kurtz, D. M. Chem. Rev. 1990, 90, 585-606.

(68) Adams, H.; Bradshaw, D.; Fenton, D. E. Inorg. Chim. Acta 2002, $332,195-200$.

(69) Holman, T. R.; Wang, Z.; Hendrich, M. P.; Que, L. Inorg. Chem. $1995,34,134-9$.

(70) Murch, B. P.; Bradley, F. C.; Boyle, P. D.; Papaefthymiou, V.; Que, L. J. Am. Chem. Soc. 1987, 109, 7993-8003.

(71) Deacon, G. B.; Phillips, R. J. Coord. Chem. Rev. 1980, 33, 227-250.

(72) Jarenmark, M.; Csapo, E.; Singh, J.; Wöckel, S.; Farkas, E.; Meyer, F.; Haukka, M.; Nordlander, E. Dalton Trans. 2010, $39,8183-8194$.

(73) Ito, K.; Bernstein, H. J. Can. J. Chem. 1956, 34, 170-178.

(74) Cotton, F. A.; Wilkinson, G.; Murillo, C. A.; Bochmann, M. Advanced Inorganic Chemistry; Wiley-Interscience Publication: New York, 1999.

(75) Drueke, S.; Wieghardt, K.; Nuber, B.; Weiss, J.; Fleischhauer, H. P.; Gehring, S.; Haase, W. J. Am. Chem. Soc. 1989, 111, 8622-8631.

(76) Brown, C. A.; Remar, G. J.; Musselman, R. L.; Solomon, E. I. Inorg. Chem. 1995, 34, 688-717.

(77) Jarenmark, M.; Turitsyna, E. A.; Haukka, M.; Shteinman, A. A.; Nordlander, E. New J. Chem. 2010, 34, 2118-2121.

(78) Greenwood, N. N.; Gibb, T. C. Mössbauer Spectroscopy; Chapman and Hall Ltd: London, 1971. 
(79) Kahn, O. Molecular Magnetism; Wiley-VCH, Publishers Inc.: New York, 1993.

(80) Simulation of the experimental magnetic data with a full-matrix diagonalization of exchange coupling and Zeeman splitting was performed with the julX program (E. Bill, Max-Planck Institute for Bioinorganic Chemistry, Mülheim/Ruhr, Germany).

(81) Buchanan, R. M.; Mashuta, M. S.; Richardson, J. F.; Webb, R. J.; Oberhausen, K. J.; Nanny, M. A.; Hendrickson, D. N. Inorg. Chem. 1990, 29, 1299-301.

(82) Schenk, G.; Peralta, R. A.; Batista, S. C.; Bortoluzzi, A. J.; Szpoganicz, B.; Dick, A. K.; Herrald, P.; Hanson, G. R.; Szilagyi, R. K.; Riley, M. J.; Gahan, L. R.; Neves, A. J. Biol. Inorg. Chem. 2008, 13, 139-155.

(83) Carlsson, H.; Haukka, M.; Nordlander, E. Inorg. Chem. 2004, 43, 5681-5687.

(84) Dietrich, M.; Münstermann, D.; Suerbaum, H.; Witzel, H. Eur. J. Biochem. 1991, 199, 105-113.

(85) Twitchett, M. B.; Schenk, G.; Aquino, M. A. S.; Yiu, D. T. Y.; Lau, T. C.; Sykes, A. G. Inorg. Chem. 2002, 41, 5787-5794.

(86) Carlsson, H.; Haukka, M.; Nordlander, E. Inorg. Chem. 2002, 41, 4981-4983.

(87) Bill, E. Mfit; Max-Planck Institute for Bioinorganic Chemistry: Mülheim/Ruhr, Germany.

(88) Otwinowski, Z.; Minor, W. In Macromolecular Crystallography, Part A; Carter, C., Sweet, J., Eds.; Academic Press: New York, 1997; Vol. 276, pp 307-326.

(89) Altomare, A.; Burla, M. C.; Camalli, M.; Cascarano, G. L.; Giacovazzo, C.; Guagliardi, A.; Moliterni, A. G. G.; Polidori, G.; Spagna, R. J. Appl. Crystallogr. 1999, 32, 115-119.

(90) Burla, M. C.; Caliandro, R.; Camalli, M.; Carrozzini, B.; Cascarano, G. L.; De Caro, L.; Giacovazzo, C.; Polidori, G.; Spagna, R. J. Appl. Crystallogr. 2005, 38, 381-388.

(91) Sheldrick, G. Acta Crystallogr., Sect. A 2008, 64, 112-122.

(92) Farrugia, L. J. Appl. Crystallogr. 1999, 32, 837-838.

(93) Sheldrick, G. M. SHELXTL, v. 6.14-1; Bruker AXS, Inc.: Madison, WI, 2005.

(94) Blessing, R. Acta Crystallogr., Sect. A 1995, 51, 33-38.

(95) Sheldrick, G. M. SADABS - Bruker Nonius scaling and absorption correction, v. 2.10; Bruker AXS, Inc.: Madison, WI, 2003.

(96) Farrugia, L. J. Appl. Crystallogr. 1997, 30, 565.

(97) Macrae, C. F.; Edgington, P. R.; McCabe, P.; Pidcock, E.; Shields, G. P.; Taylor, R.; Towler, M.; van de Streek, J. J. Appl. Crystallogr. 2006, 39, 453-457.

(98) Bunton, C. A.; Farber, S. J. J. Org. Chem. 1969, 34, 767-772. 